\title{
CRÍTICA DOS DIREITOS HUMANOS À LUZ DA LEITURA DE ISTVÁN MÉSZÁROS
}

\author{
Rafael de Sá Menezes \\ Professor Marcus Orione Gonçalves Correia
}

São Paulo

2013 


\section{CRÍTICA DOS DIREITOS HUMANOS À LUZ DA LEITURA DE ISTVÁN MÉSZÁRIOS}

Rafael de Sá Menezes

Dissertação apresentada à Universidade de São Paulo para obtenção do título de Mestre em Direito

Área de concentração:

Direitos Humanos

Orientador: Professor Doutor Marcus Orione Gonçalves Correia

São Paulo 2013 
Catalogação da Publicação

Faculdade de Direito da Universidade de São Paulo

SÁ MENEZES, Rafael.

Crítica dos Direitos Humanos à luz da Leitura de István Mészáros / Rafael de Sá Menezes; orientador Marcus Orione Gonçalves Correia. - São Paulo, 2013.

$104 \mathrm{fl}$.

Tese (Mestrado) - - Universidade de São Paulo, 2013.

1. Direitos humanos, crítica, alienação, István Mészáros. 
Nome: SÁ MENEZES, Rafael.

Título: Crítica dos Direitos Humanos à luz da Leitura de István Mészáros.

Dissertação apresentada à Faculdade de Direito da Universidade de São Paulo para a obtenção do título de Mestre em Direito

Aprovado em:

Banca Examinadora

Prof. Dr. Instituição:

Julgamento: Assinatura:

Prof. Dr. Instituição:

Julgamento: Assinatura:

Prof. Dr. Instituição:

Julgamento: Assinatura: 
Para Cláudia Lessa 


\section{AGRADECIMENTOS}

Gostaria de expressar meus agradecimentos, que pela singeleza talvez não expressem tão bem seu valor, aos amigos, companheiros e colegas que, durante esta trajetória estiveram comigo e de algum modo acompanharam uma parte ou todo o processo de construção deste trabalho.

Primeiramente, aos valorosos companheiros de tantas lutas, tantas batalhas e tantas esperanças, com os quais dividi tantos aprendizados e que me ajudaram e ajudam a refletir criticamente sobre os problemas da nossa sociedade, dos quais posso mencionar, penalizando-me por não poder apontar todos, Vinícius Mota, Gabriel Muniz, Renan Quinalha, Marina Ganzaroli, Mayna Dias, Ricardo Leite Ribeiro, Talita Melo, Caio Santiago, Maia Aguilera, João Bosco, Aleksei Neves, Danilo Queiroz, Aline Viotto, lagê Miola, Aldo Sauda, Rodolfo Valente, Ronaldo Pagotto, Ney Strozake, João Paulo Rodrigues e Amelinha Teles.

A meus colegas de pós-graduação, cujas discussões no nosso grupo de estudos e para além deste contribuíram e continuam a contribuir: William Castanho, Flávio Roberto Batista, Pablo Biondi, Jonnas Vasconcelos, Danilo "Padre", Aton Fon, Thiago Barison, Isadora Brandão, Pedro Muller e Luciano Palhano.

A meu orientador Marcus Orione Gonçalves Correia, pela atenção constante e permanente, pela leitura e pela crítica sempre precisa, com anotações que contribuíram enormemente para o desenvolvimento deste trabalho.

Ao Des. Walter Piva Rodrigues, pela compreensão e fraterno apoio sempre dispensado.

Aos saudosos colegas de Tribunal de Justiça: José Jair Marques Junior, Leonardo Gonzales, Leonardo Manso Vicentin, Marina Rodrigues, Livia Maria Parisotto, Marilia Golfieri, Felipe Oliva, Rodrigo Barcellos e Daniel Oliveira. 
Aos amigos da Defensoria Pública: Paulo de Divitiis, Mariana Guarda, Fernanda Balera, Felipe Hotz, Estela Guerrini, Fernanda Elias Maglio, Gabriel Maglio e Patrick Cacicedo.

Aos amigos da lida diária da Defensoria de Itaquera: Andrea Brunhari, Gladston Correia, Tatiana Fortes, Renata Scandiuzzi, Laura Naves, Mariana Figueiredo, Vanessa Chalegre, Vanessa Riguete, Rafael Negreiros, Débora Pezzuto, Diogo "Fandangos", Maíra Dias e Luiz Felipe.

Um especial agradecimento a minha família, que, próxima ou distante, sempre me deu forças para caminhar: Ligia Cintra de Lima Trindade, Lair Lessa, Cláudia Lessa, Rivalda Maria Cintra Gonçalves, José Damião de Lima Trindade, Viviane de Sá Menezes, Manuela de Sá Menezes, Artur de Sá Menezes Neto e Ricardo de Sá Menezes.

A meus queridos amigos: Pedro Pereira Leite, Daniel Costa, Murilo de Sá Menezes, meu primo amigo, Vladimir Sampaio, Caio Rioei Ferreira, Flávio Marques Prol, Flávia Annemberg, Gabriela Pimenta, Riccardo Silva, Yasmim Pestana, Bruna Trevelin, Vinicius Saragiotto, Mariana Nogueira, Fernanda Félix, Ellen Pimenta e Geovana Rodrigues.

Por fim, aos que, não mencionados aqui nominalmente por acidente, estiveram comigo na trajetória que me levou a concluir esta etapa acadêmica. 
"Já Dom Quixote pagou pelo erro de presumir que a cavalaria andante seria compatível com qualquer estrutura econômica da sociedade".

K. Marx 
RESUMO

SÁ MENEZES, R. Crítica dos Direitos Humanos à luz da Leitura de István Mészáros. 104 fl. Tese (Mestrado) - Faculdade de Direito, Universidade de São Paulo, São Paulo, 2013.

Neste trabalho, realiza-se uma leitura da obra de István Mészáros, especificamente das que versam sobre a temática do direito e dos direitos humanos. István Mészáros desenvolve uma crítica externa aos direitos humanos, não se tratando de uma crítica imanente do direito, mas de uma crítica que se desenvolve no âmbito de uma obra que engloba diversas questões filosóficas, sociológicas, econômicas, políticas e jurídicas. István Mészáros entende que os direitos humanos são uma questão de "alta relevância" quando o "livre desenvolvimento das individualidades" aparece como um horizonte da luta social e, por isso, o que está em jogo é a superação das mediações de segunda ordem do sistema sociometabólico do capital e o desenvolvimento positivo de um sistema alternativo, que não exclui as mediações de primeira ordem, inclusive de uma superestrutura alternativa correspondente ao controle consciente da reprodução social pelos produtores associados. Neste sentido, o trabalho analisa o modo como István Mészáros examina a questão dos direitos humanos, propondo, a partir de tal análise, que há uma vigorosa metodologia crítica desenvolvida pelo autor. Neste sentido, conclui-se que a teoria de István Mészáros é de grande valia para compreender o modo como se deve lidar com a questão dos direitos humanos numa perspectiva crítica, isto é, numa perspectiva que leve em conta a necessária historicidade da normatividade alienada (medida externa) e se apoie nas mediações de primeira ordem para propor uma alternativa superestrutural viável ao novo contexto (medida interna, autodeterminação).

Palavras-chave: Direitos humanos, crítica, alienação, István Mészáros. 
SÁ MENEZES, R. Critical Analysis of Human Rights under the Reading of István Mészáros. $104 \mathrm{fl}$. Tese (Mestrado) - Faculdade de Direito, Universidade de São Paulo, São Paulo, 2013.

In this work, we make a reading of the work of István Mészáros, specifically those that deal with the themes of law and of human rights. István Mészáros develops a external critics to human rights, not an immanent critique of law, but a critique that develops within a work that encompasses many philosophical, sociological, economic, political and legal problems. István Mészáros see that human rights are a matter of "great importance" when the "free development of individualities" appears as a horizon of social struggle and, therefore, what is at stake is the overcoming of second order mediations of the capital's sociometabolic system and the positive development of an alternative system, which does not exclude the first order mediations, including an alternative superstructure corresponding to the conscious control of social reproduction by the freely associated producers. In this sense, the work examines how István Mészáros examines the issue of human rights, proposing, from this analysis, that there is a vigorous critical methodology developed by the author. In this sense, it is concluded that the theory of István Mészáros is valuable to understand how one should deal with the issue of human rights in a critical perspective, i. e., a perspective that takes into account the necessary historicity of alienated normativity (external measure) and support the first order mediations to propose an alternative viable superstructure to the new context (as internal self-determination).

Keywords: Human Rights, Critical, Alienation, István Mészáros. 


\section{SUMÁRIO}

página

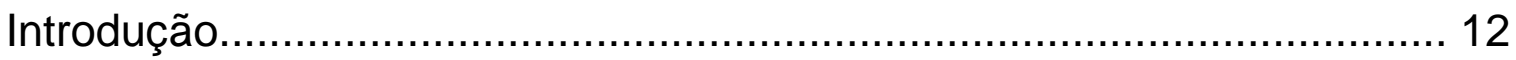

Parte I: O pensamento de István Mészáros

Capítulo 1: Uma Filosofia para Entender a Crise Atual................... 17

Capítulo 2: Superestrutura Jurídica e a Teoria das Mediações........ 28

Parte II: A crítica aos direitos humanos: uma metodologia materialista

histórica a partir da leitura de István Mészáros

Capítulo 3: "Direitos do homem": negatividade e positividade da crítica.

Capítulo 4: A contradição entre a enunciação de garantias de direitos e a ineficácia destes. 55

Capítulo 5: A crítica às concepções jurídicas dominantes e a avaliação do sistema de direito 65

Capítulo 6: A busca das condições de não-anulabilidade da vontade individual e o lado ativo dos direitos humanos..... 74

Conclusões. 90

Bibliografia. 96 


\section{INTRODUÇÃO}

Neste trabalho, propõe-se uma leitura de obras do filósofo István Mészáros com a finalidade de nelas buscar referências aos "direitos humanos" e a matérias correlatas que possam contribuir para a crítica de tais direitos. Assim, pretende-se buscar especificamente em tais obras referências à superestrutura jurídica e à sua relação com as lutas sociais, buscando contribuir para o desenvolvimento de uma teoria crítica dos direitos humanos. Esta delimitação ao trabalho bibliográfico se justifica em razão da necessidade de restringir o objeto de pesquisa, viabilizando a elaboração da presente dissertação, de modo a deixar para investigações futuras o aprofundamento de alguns temas que, ao longo deste trabalho, serão apenas tangenciados.

A motivação para tal trabalho surge da insuficiência teórica da crítica sobre o modo como os movimentos sociais ${ }^{1}$ lidam com os direitos humanos, ou, em suma, da relação entre a luta social ${ }^{2}$ e a teoria dos direitos humanos. É correto apontar que tais direitos são necessários à reprodução do sistema sociometabólico do capital e que serão superados quando este mesmo sistema não mais subsistir, mas isto acrescenta pouco à positividade demandada pela luta social concreta. Assim, busca-se, com a leitura de István Mészáros, estabelecer elementos para uma melhor compreensão desta relação entre teoria dos direitos humanos e as lutas sociais.

Neste trabalho, ver-se-á que István Mészáros entende que os direitos humanos são uma questão de "alta relevância" quando o "livre desenvolvimento

1 A perspectiva teórica adotada é a marxista, donde o termo "movimentos sociais" é utilizado ao longo do trabalho não para se referir a qualquer movimento coletivo de demanda ou luta social, mas a movimentos de extração classista, isto é, movimentos que tenham como pauta ou como pressuposto de suas demandas ou lutas o pertencimento à classe trabalhadora. Assim, neste trabalho, em muitas passagens se utilizará o termo "movimentos sociais" para, de forma simplificada, fazer referência aos sujeitos históricos e sociais do trabalho, isto é, à "classe-que-vive-do-trabalho" ou "classe-que-vive-da-alienação-da-própria-força-de-trabalho". A referência a "Iutas sociais" ao longo do trabalho também dizem respeito às lutas protagonizadas por tais sujeitos. Esta terminologia está conforme a utilizada por $\mathrm{R}$. ANTUNES. Adeus ao trabalho? Ensaio sobre as metamorfoses e a centralidade do mundo do trabalho, 2000.

2 Observação semelhante à feita da nota de rodapé anterior se aplica à utilização do termo "luta social" - trata-se, assim, não de qualquer luta social, mas da luta social orientada à superação do modo de produção capitalista e à construção de uma sociedade baseada no trabalho livre e associado. 
das individualidades" aparece como um horizonte da luta social ${ }^{3}$. A partir desta perspectiva, se espera contribuir para a reflexão sobre se o discurso e a prática sobre os direitos humanos dos movimentos sociais emancipatórios possuem potencial emancipatório ou se estão fadados a sucumbir nos emaranhados do direito e do formalismo jurídico.

Como mencionado, o trabalho terá como referência a leitura de István Mészáros, com sua contribuição para a discussão sobre a relação entre a estrutura social e a superestrutura jurídica, bem como sua específica leitura sobre os direitos humanos. Mas não se pretende dar uma contribuição para a dogmática dos direitos humanos, o que seria em grande medida inviável nos limites deste trabalho e da obra de István Mészáros. Os meandros da análise dogmática, assim, serão deixados de lado, e caso alguma consequência possa ser tirada neste âmbito, não será porque tenha estado no escopo do trabalho. As preocupações principais se voltam não para o conhecimento prático do direito, mas para o âmbito do conhecimento teórico do mesmo, isto é, para o estudo da questão dos direitos humanos sem as amarras de um sistema de normas posto. A análise a ser realizada, por seu turno, além de transitar nos campos da filosofia e da sociologia do direito, pretende colocar-se no campo da crítica, a qual aponta para uma análise sob a luz da totalidade, isto é, sob uma luz que leve em conta todas as determinações importantes num dado contexto histórico acerca da categoria "direitos humanos".

O texto tomado como referência principal para este trabalho é "Marxismo e Direitos Humanos" ${ }^{4}$, de István Mészáros, apresentado na Conferência de Dublin, em 1978, por ocasião do 30 aniversário da Declaração dos Direitos Humanos das Nações Unidas. A partir da sua leitura, a questão teórica que se coloca é a da relação entre marxismo e direitos humanos, apontando para os fundamentos e as limitações da análise crítica sobre os "direitos do homem" realizada por Marx, conforme síntese elaborada por István Mészáros no referido texto.

O que há de central na categoria de direitos humanos (ou seja, quais são algumas das mais importantes de suas múltiplas determinações): que eles são

3 I. MÉSZÁROS. Marxismo e Direitos Humanos, 2008, p. 168.

4 No original, em inglês, o texto intitula-se "Marxism and Rights". 
direitos positivados e garantidos pelo Estado e por instrumentos e instituições internacionais? Que eles são direitos de liberdade e igualdade formais necessários para e funcionais à reprodução do capital? Que eles são a expressão das necessidades (do estômago ou da fantasia) de certos grupos sociais que aparecem como bandeiras de luta diante das restrições impostas e legitimadas pelo Estado e pelo sistema sociometabólico do capital?

Certamente, definir o que há de central nos direitos humanos, na perspectiva da crítica, não é uma tarefa simples, pois exige que a totalidade das determinações em questão, num dado momento histórico, seja levada em conta na análise da categoria. No contexto atual, as três questões formuladas no parágrafo anterior conformam determinações múltiplas da categoria direitos humanos, e pode-se dizer que conformam as mais importantes determinações para a sua conceituação, às quais se chega com aproximações sucessivas à referida categoria. Aquelas três questões se relacionam com os elementos daquilo que Ricardo Antunes chamou de o núcleo constitutivo do "sistema de sociometabolismo do capital", formado pelo tripé Estado, capital e trabalho ${ }^{5}$. Estes três elementos nada mais são do que as principais esferas determinantes da vida social sob o capitalismo - as quais possuem uma ação recíproca na história. Neste sentido, uma perspectiva crítica (portanto, totalizante) dos direitos humanos deveria atentar ao menos para o modo como tais direitos aparecem em cada uma destas esferas.

A preocupação central deste trabalho, neste sentido, é, a partir da leitura de István Mészáros, desenvolver uma reflexão crítica sobre os direitos humanos, de modo a apoiar a compreensão sobre o significado da incorporação das pautas de direitos humanos por movimentos sociais emancipatórios, movimentos que preconizem a superação da forma jurídica atrelada ao sistema sociometabólico do

5 R. ANTUNES. Apresentação a I. MÉSZÁROS. Para Além do Capital, 2002, p. 16, que explica que "estas três dimensões fundamentais do sistema são materialmente constituídas e interrelacionadas e é impossível superar o capital sem a eliminação do conjunto dos elementos que compreende este sistema. Não basta eliminar um ou mesmo dois de seus pólos. Os países pós-capitalistas, com a URSS à frente, mantiveram intactos os elementos básicos constitutivos da divisão social hierárquica do trabalho que configura o domínio do capital. A 'expropriação dos expropriadores', a eliminação 'jurídico-política' da propriedade, realizada pelo sistema soviético, 'deixou intacto o edifício do sistema do capital'. O desafio, portanto, é superar o tripé em sua totalidade, nele incluído o seu pilar fundamental, dado pelo sistema hierarquizado de trabalho, com sua alienante divisão social, que subordina o trabalho ao capital, tendo como elo de complementação o Estado político". 
capital. A questão que se coloca, quanto a tal incorporação, é a de se os direitos humanos, postos como uma alternativa hegemônica, não seriam definitivamente restringidos pela ordem existente por dependerem do objeto que negam, isto é, por dependerem do Estado que Ihes valida e garante ou do mercado que lhes pressupõe.

Como se verá, na perspectiva de Mészáros, a superestrutura jurídica é ínsita ao capitalismo, dando a este a coesão necessária para a sua insuperável centrifugalidade $^{6}$. Isto não significa que toda forma de normatividade decorra do controle sociometabólico do capital, nem que a teoria crítica não deva nutrir preocupações sobre formas alternativas de normatividade, congruentes com a renovada base material que despontará das contradições atuais. Bem entendido, não se trata de extirpar toda regulação social, mas de pesquisar quais seriam, num período de transição, os meios de controle social correspondentes às necessidades e às possibilidades de cada agente envolvido, a partir do que se poderia começar a pensar em meios de controle da produção e da reprodução social pelos próprios produtores envolvidos. Neste sentido, a teoria de István Mészáros é de grande valia para compreender o modo como se deve lidar com a questão dos direitos humanos numa perspectiva crítica, isto é, numa perspectiva que leve em conta a necessária historicidade da normatividade alienada (medida externa $^{7}$ ) e que se apoie nas mediações primárias para viabilizar que, no momento adequado, seja proposta uma alternativa superestrutural viável ao novo contexto (medida interna, autodeterminação).

Com isso, pretende-se contribuir para desvendar a razão pela qual o discurso dos direitos humanos passa a ser largamente utilizado como bandeira de luta por movimentos sociais no contexto atual, quando, em contraste, no passado, era tido até mesmo como contraposto ao discurso marxista ou socialista.

6 I. MÉSZÁROS. Estrutura Social e Formas de Consciência II, 2011, p. 160, que esclarece que "a relação de valor deve ser, em princípio, ilimitável, de acordo com as determinações mais profundas do sistema do capital em desdobramento, de modo que se torne um sistema coesivo. Portanto, posto que a coesão necessária não pode ser alcançada sobre a base substantiva dos microcosmos materiais autoexpansivos em si, somente a universalidade formal das determinações imperativas do Estado podem completar o modo de reprodução social metabólica do capital como um sistema, oferecendo, dessa maneira uma saída da contradição da insuperável centrifugalidade".

7 Sobre a distinção entre medida interna e medida externa, vide I. MÉSZÁROS. A Teoria da Alienação em Marx, 2006, p. 172. 
A premissa fundamental deste trabalho é a de que os direitos humanos são uma categoria contraditória. Expressam-se, por um lado, como bandeiras de luta de movimentos sociais decorrentes de necessidades humanas; por outro lado, como direitos reconhecidos e positivados pelo Estado, decorrentes de concessões que visam a manter a reprodução sociometabólica em funcionamento e a aplacar a conflitividade social; aparecem ainda como direitos necessários às práticas de mercado, na consagração da liberdade e igualdade formais. Neste sentido, nem são o reflexo da emancipação alcançada (garantias formais de direitos não são suficientes para tanto), nem são meros instrumentos de dominação de classe ou pautas sem relevância para as lutas emancipatórias (a determinação em última instância do direito pelas bases materiais não exclui a existência de relações contraditórias no seio da realidade jurídica, as quais precisam ser equacionadas pela crítica).

Observe-se que os direitos humanos existem no contexto do capitalismo, surgem neste contexto e nele se desenvolvem, donde a necessária delimitação histórica, pela qual se exclui da noção de direitos humanos abordada neste trabalho supostas expressões que estejam inseridas em outros contextos históricos - é dizer, nesta perspectiva, falar em "direitos humanos" fora de sua contextualização própria ou com pretensões a-históricas seria um equívoco. Ao mesmo tempo, se o fundamento dos mesmos está nas lutas sociais e nas reinvindicações por acesso à produção social, tais "direitos" estariam de alguma forma presentes antes do capitalismo, porém, só poderiam aparecer completamente desvinculados da superestrutura jurídica existente no contexto do sistema sociometabólico do capital. 


\section{PARTE I - O PENSAMENTO DE ISTVÁN MÉSZÁROS}

\section{CAPÍTULO 1: UMA FILOSOFIA PARA ENTENDER A CRISE ATUAL}

Para István Mészáros, "vivemos numa época de crise histórica sem precedentes que afeta todas as formas do sistema do capital, e não apenas o capitalismo"8. Esta afirmação, feita em 2000, no prefácio à edição brasileira de "Para Além do Capital", continua de grande atualidade mais de uma década depois. A crise histórica a que se referia István Mészáros era não uma das crises econômicas ou financeiras que os jornais noticiam com enfadonha frequência, mas uma crise estrutural do "sistema sociometabólico do capital", a qual possui alcance, abrangência e consequências muito mais profundas do que crises econômicas pontuais. Com efeito, segundo István Mészáros, estar-se-ia diante não de uma crise conjuntural, mas de uma crise estrutural que, embora não tenha precedentes, esteve implícita no desenvolvimento do sistema sociometabólico do capital. O sinal mais evidente da crise estrutural é a destrutividade e o modo perdulário com que o consumo se expande no contexto atual ${ }^{9}$, levando as próprias condições de reprodução do capital a um limite não mais aceitável pela natureza encontrada pelo ser humano no planeta Terra.

A crise em questão, para István Mészáros, é o aprofundamento do período histórico descendente da hegemonia do capital. No seu período ascendente, o capital manteve um dinamismo inerente e um potencial expansivo que colonizou toda a humanidade, em direção à formação de um sistema mundial, esmagando "as forças que se lhe opõem em muitos 'pequenos cantos' do mundo" ${ }^{10}$ enquanto

8 I. MÉSZÁROS. Para Além do Capital, 2002, p. 21.

9 Esta destrutividade explicita uma das conclusões de K. MARX, F. ENGELS. A Ideologia Alemã, 2007, p. 41, sobre a concepção de história por eles desenvolvida: "No desenvolvimento das forças produtivas advém uma fase em que surgem forças produtivas e meios de intercâmbio que, no marco das relações existentes, causam somente malefícios e não são mais forças de produção, mas forças de destruição (maquinaria e dinheiro) - e, ligada a isso, surge uma classe que tem de suportar todos os fardos da sociedade sem desfrutar de suas vantagens e que, expulsa da sociedade, é forçada à mais decidida oposição a todas as outras classes..."

10 I. MÉSZÁROS. Para Além do Capital, 2002, p. 591. A expressão "pequeno canto do mundo" é uma referência de István Mészáros a Marx, especificamente à Carta a Engels de 8 de dezembro de 1857, onde ele afirma que "Não se pode negar; a sociedade burguesa vive seu segundo século $\mathrm{XVI}$, o qual, espero, a levará para o túmulo, tal como o primeiro a trouxe à 
ampliava o círculo de consumo e derrubava as barreiras que restringiam o desenvolvimento do sistema sociometabólico do capital. Nesta fase, avanços e transformações sociais sem precedentes acontecem, "graças à reciprocidade positiva e interdependência de seu processo reprodutivo", com um papel significativo da dimensão superestrutural, "do comprometimento político antifeudal à grande contribuição emancipatória da arte e da literatura, bem como às aspirações universalistas genuínas, ainda que de certa forma ingênuas e, por fim, malogradas, da filosofia iluminista"11.

Por outro lado, entretanto, na fase descendente "as condições de reprodução expandida do sistema foram radical e irremediavelmente alteradas, empurrando para o primeiro plano suas tendências destrutivas e seu companheiro natural, o desperdício catastrófico"12. Destrutividade e desperdício que são possíveis apenas com a abundância dos produtos do trabalho ${ }^{13}$, a qual, em razão do modelo econômico adotado, ao invés de se direcionar à satisfação das necessidades humanas, fica sob controle dos imperativos reprodutivos do sistema sociometabólico vigente, ocasionando crises sucessivas e subsequentes reajustes apenas parciais.

Como exemplo de um dos aspectos que contribuem para referida crise,

vida. A tarefa histórica da sociedade burguesa é o estabelecimento de um mercado mundial, ao menos em seus contornos básicos, em um modo de produção que descansa sobre esta base... para nós a questão mais difícil é esta: a revolução no continente é iminente e terá, desde o início, caráter socialista; não será ela necessariamente esmagada neste pequeno canto do mundo, já que num terreno muito mais amplo o desenvolvimento da sociedade burguesa está ainda na ascendente"?

11 I. MÉSZÁROS. Estrutura Social e Formas de Consciência II, 2011, p. 140.

12 I. MÉSZÁROS, O Século XXI. Socialismo ou Barbárie, 2003, p. 22.

13 LESSA, Sérgio. Modo de produção e revolução: Lukács e Mészáros. Revista Eletrônica Germinal, v. 1, n. 1 (2009), p. 66-83, disponível em http://www.uel.br/revistas/uel/index.php/ germinal/issue/view/316, consulta em 28 de janeiro de 2011. Segundo o autor, o salto ontológico da humanidade levou esta da carência à abundância; ocorre que, enquanto "na acumulação primitiva, com a carência vigendo, a procura tendia a ser maior do que a oferta, garantido um patamar de preços condizente com a acumulação do capital", no século XIX a "abundância fez com que a oferta" fosse "tendencialmente superior à procura", de modo que "os preços tendem a cair, a taxa de lucro tende a diminuir por toda a economia e o capitalismo, maduro, passa a viver sucessivas crises de superprodução... Por isso, para que a reprodução do capital prossiga é decisivo o desenvolvimento de relações sociais que convertam a abundância em carência pelo maior desperdício possível: a sociedade burguesa vai desenvolvendo complexos sociais que potencializem a perdulariedade de todo o sistema... É isto que Mészáros, em uma formulação insuperável, denominou de 'produção destrutiva': a produção da abundância, a maior riqueza humana historicamente possível, é convertida pelas mediações das alienações que brotam do capital nas misérias de nossos dias...". 
cabe citar a taxa decrescente de utilização, formulação original de István Mészáros que expressa o modo pelo qual os imperativos do valor de troca se impõem sobre o valor de uso: as mercadorias tornam-se mais e mais descartáveis, no interesse da contínua reprodução do capitalismo, não importa o quão perdulário isto possa ser, mesmo quando coloque em risco o futuro da humanidade.

Como sintoma da crise estrutural em andamento estaria o fato de que o capital não tem "mais condições de oferecer qualquer ganho significativo ao interlocutor racional [o trabalho], mas ao contrário, foi obrigado a retomar concessões passadas" acometendo "as próprias bases do Estado de bem-estar, bem como as salvaguardas legais de proteção e defesa do operariado por meio de um conjunto de leis autoritárias contrárias ao movimento sindical, todas aprovadas democraticamente"14, de modo que "no interesse de salvaguarda e da parcialidade auto-orientada e da insuportável hierarquia estrutural do capital, aborta-se a prometida universalidade potencial no desenvolvimento das forças produtivas" 15 .

A fase descendente do desenvolvimento capitalista envolve uma crescente juridicização das relações sociais. Esta juridicização reflete uma tendência de persistência das estruturas capitalistas conflitivas e contraditórias, que se autorreproduzem a todo custo apesar dos crescentes desperdícios, destrutividade e desigualdade existentes. Para István Mészáros, o "papel crescentemente negativo da superestrutura jurídica e política nos processos reprodutivos materiais, prevalecente no curso da fase descendente do desenvolvimento do sistema do capital, é não só óbvio, mas também extremamente perigoso" ${ }^{16}$. Esta obviedade aparece na constatação de que a superestrutura jurídica e política oferece o instrumental operativo adequado para a expansão (ainda que isso implique em destrutividade) e manutenção da lógica reprodutiva do capital a qualquer custo. O perigo existente, por seu turno, está justamente no potencial esgotamento dos recursos naturais disponíveis para este tipo de reprodução

14 I. MÉSZÁROS. Para Além do Capital, 2002, p. 24.

15 I. MÉSZÁROS, O Século XXI. Socialismo ou Barbárie, 2003, p. 19. Por esta razão é que se tem afirmado que um discurso ambientalista consequente entra em confronto direto com esta característica do capitalismo.

16 I. MÉSZÁROS. Estrutura Social e Formas de Consciência II, 2011, p. 154. 
social, o que conduziria não só à inviabilidade deste tipo de reprodução, mas à de qualquer tipo de reprodução humana rica.

A forma jurídica é necessária para o modo de reprodução capitalista, segundo István Mészáros, pois

\begin{abstract}
"a coesão necessária [ao capitalismo] não pode ser alcançada sobre a base substantiva dos microcosmos materiais autoexpansivos em si, somente a universalidade formal das determinações imperativas do Estado podem completar o modo de reprodução social metabólica do capital como um sistema, oferecendo dessa maneira uma saída da contradição da insuperável centrifugalidade" ${ }^{" 17}$.
\end{abstract}

Tanto que "No passado distante de sua constituição original, ela [a superestrutura jurídica e política] teve de surgir das condições operacionais socioeconomicamente essenciais do processo de reprodução material, com o qual formou, a princípio, uma unidade orgânica" ${ }^{18}$. Acrescentando que "Foi preciso o transcorrer de muitos séculos antes que algumas determinações regulatórias originais do desenvolvimento produtivo pudessem ser separadas de sua configuração orgânica e transformadas na preponderância hoje ubíqua da superestrutura jurídica e política, sob os requisitos do modo de reprodução social metabólica do capital”19.

Numa perspectiva crítica, a compreensão do direito é "não mais aquela da filosofia do direito moderna, na qual o fenômeno jurídico era pensado a partir de uma ideia ou um conceito de justo. O direito não é um produto histórico do melhor aclaramento da consciência do jurista, nem tampouco da melhor elaboração dos conceitos. Na verdade, o direito se constitui pela necessidade histórica de as relações produtivas capitalistas estabelecerem determinadas instâncias que possibilitem a própria reprodução do sistema"20.

O papel da filosofia do direito crítica é explicitar o modo de ser tanto da dogmática jurídica quanto das teorias do direito, inclusive o das próprias filosofias do direito. Daí a crítica concluir, a partir da análise de tais teorias, que o direito não nasce da vontade geral, nem de um direito natural eterno e racional,

17 I. MÉSZÁROS. Estrutura Social e Formas de Consciência II, 2011, p. 160.

18 Idem, p. 134.

19 Idem

20 A. L. MASCARO. Filosofia do Direito, 2011, p. 294. 
tampouco se liga às necessidades de bem comum e a verdades transcendentes ${ }^{21}$, mas "à própria práxis, à história social e reprodutiva do homem"22. A perspectiva crítica contrapõe-se, assim, a teorias idealistas da filosofia do direito, que desprezam a totalidade em desenvolvimento dos objetos para dedicar-Ihes teorias parciais, que deixam de lado interessadamente aspectos relevantes do real ${ }^{23}$.

No capítulo seguinte será aprofundado o estudo do tema da superestrutura jurídica em István Mészáros.

A teoria de István Mészáros tem como pano de fundo a distinção entre capital e capitalismo, sendo aquele um "sistema de comando cujo modo de funcionamento é orientado para a acumulação" ${ }^{24}$, enquanto o capitalismo é uma forma específica que este sistema toma em certos contextos. A crítica de István Mészáros ao regime estabelecido na URSS se apoiava nesta distinção, com a constatação de que o "socialismo" instaurado nas repúblicas soviéticas superara o capitalismo, mas não o capital enquanto sistema metabólico socioeconômico de controle da reprodução. O regime soviético com seu "socialismo realmente existente" não teria sido capaz de superar as contradições decorrentes da separação entre produtor e produção, mantendo a divisão do trabalho e as estruturas hierárquicas de comando, embora com um modo "pós-capitalista de extrair o trabalho excedente a uma taxa imposta por meios políticos diretos, criando um novo tipo de imposição do imperativo-de-tempo, que serve ao sistema do capital em todas as suas formas historicamente viáveis" 25 .

A perspectiva filosófica de István Mészáros é ontológica, no sentido de que vislumbra um fator absoluto da condição humana, qual seja, a automediação do homem com a natureza, uma base ontologicamente necessária, expressa nas

21 Idem, p. 295.

22 Idem.

23 Estas filosofias do direito se afastam da busca filosófica da verdade e permanecem, como as ciências, no campo das abstrações puras, de modo que, em suas descrições, elas também "omitem seja o sujeito (abstrato) que corresponde ao objeto (abstrato) que descrevem, seja o objeto (abstrato) que é oferecido ao sujeito (abstrato) que estudam", conforme descreve, sobre o modo de proceder da ciência, A. KOJĖVE. Introdução à Leitura de Hegel, 2002, p. 428.

24 I. MÉSZÁROS. O Marxismo Hoje: Entrevista com István Mészáros, p. 130.

25 I. MÉSZÁROS. Para Além do Capital, 2002, p. 897. 
mediações de primeira ordem ou mediações primárias ${ }^{26}$. Esta mediação fundamental entre ser humano e natureza, que constitui a própria atividade produtiva, se dá pelo trabalho, o qual aparece no específico contexto histórico atual como trabalho alienado. O trabalho é a condição natural para a realização do ser humano, mas chega, no contexto atual, a tornar-se seu algoz ${ }^{27}$, pois as mediações de segunda ordem comprometem e subordinam as condições naturais absolutas. Para Marx, em tal contexto, "o trabalho mesmo se torna um objeto"28 e este objeto se torna uma "força autônoma" diante do trabalhador, significando "que a vida que ele concedeu ao objeto se lhe defronta hostil e estranha" ${ }^{29}$, de modo que a relação social se torna uma relação entre coisas ${ }^{30}$. Para István Mészáros, cabe apontar e distinguir quais são as mediações primárias e as mediações das mediações historicamente específicas, tratando-se de um modo adequado para compreender e confrontar os problemas decorrentes da separação entre os produtores e sua produção.

A distinção entre estas mediações (de primeira ordem e de segunda ordem) é um dos traços mais marcantes da teoria de István Mészáros, constituindo, efetivamente, o ponto nevrálgico de seu sistema filosófico, como se verá no desenvolvimento do presente trabalho. Trata-se, ademais, de uma teoria que pode dar grande contribuição para a compreensão dos problemas relativos às lutas sociais atuais, em específico, para o que interessa neste trabalho, ao discurso e prática dos direitos humanos observados nestas lutas.

Estas mediações primárias estão em contraste com as mediações de segunda ordem existentes no contexto histórico específico atual. Não se pode olvidar, neste sentido, que o que está em jogo na transformação da sociedade é a mediação em geral, num sentido duplo, com a crítica negativa da "mediação da mediação" e com a promoção de alternativas que não podem desprezar, em sua formulação, as mediações primárias ${ }^{31}$. A busca por uma transformação radical ${ }^{32}$

26 Vide, a este respeito, por exemplo, I. MÉSZÁROS. Estrutura Social e Formas de Consciência, 2009, p. 192, Para Além do Capital, 2002, p. 212-213, e A Teoria da Alienação em Marx, 2006, p. 78 , bem como a pg. 24 deste trabalho para uma discussão sobre as mediações de primeira ordem.

27 Esta formulação aparece em L. KONDER. O que é dialética, 1998, p. 29.

28 K. MARX. Manuscritos Econômico-filosóficos, 2004, p. 81.

29 Idem.

30 K. MARX, O Capital, 1971, p. 71.

31 Necessário esclarecer que mediações primárias não são mediações absolutas ou naturais no 
envolve, assim, a luta pela superação da alienação nas mais diversas dimensões da vida humana, como a econômica, a cultural, a política e a jurídica. Envolve, estruturalmente, uma organização do trabalho pela qual os produtores livremente associados controlem a produção material e os intercâmbios culturais ${ }^{33}$, de maneira autodeterminada. Mas aquela busca deve envolver "as 'microestruturas' (como a família) tanto quanto as instituições mais abrangentes (as 'macroestruturas') da vida política e econômica", sendo que "o critério crucial para a avaliação de medidas parciais é se são ou não capazes de operar como 'pontos de Arquimedes', ou seja, como alavancas estratégicas para uma reestruturação radical do sistema global de controle social”34.

István Mészáros desenvolve com apurado rigor um tema central do método marxista, qual seja, o método dialético. O método dialético, em seu sentido filosófico atual, foi desenvolvido primeiramente por Hegel. Marx empreendeu, na construção de seu sistema, uma crítica da dialética hegeliana e a defesa de um método dialético atrelado à concepção materialista da história.

Marx realizou uma guinada da maior importância na filosofia ocidental. Com base na filosofia marxiana é possível demonstrar como o pensamento sem pressupostos e a dúvida metódica de Hegel se desenvolveram em direção a sínteses ideais, que fundamentam o sistema hegeliano num "círculo dos círculos" e acabam por afastar este sistema de sua anunciada preocupação com o emparelhamento entre conhecimento e ser.

Assim, a crítica marxista esclarece que o modo de proceder idealista da

sentido jusnaturalista; a partir da leitura de István Mészáros, pode-se concluir que o absoluto e o natural, no marxismo, têm também a marca do histórico.

32 Numa síntese compreensiva, R. ANTUNES. Introdução. A Substância da Crise, in I. MÉSZÁROS A Crise Estrutural do Capital, 2009, p. 16, afirma que "Criar um modo de produção e vida profundamente distinto do atual é, portanto, um desafio vital lançado por István Mészáros. A construção de um novo sistema sociometabólico, de um novo modo de produção baseado na atividade autodeterminada, na ação dos indivíduos livremente associados (Marx) e em valores para além do capital. A atividade baseada em tempo disponível para produzir valores de uso socialmente úteis e necessários - contrária à produção baseada no tempo excedente para a produção exclusiva de valores de troca para a reprodução do capital - torna-se vital".

33 I. MÉSZÁROS, O Século XXI. Socialismo ou Barbárie, 2003, p. 21: "Diante da crise estrutural do capital enquanto tal... é importante ainda sublinhar que os problemas são fatalmente agravados no estágio atual de desenvolvimento, inserindo na agenda histórica a necessidade de um controle global viável da produção material e dos intercâmbios culturais da humanidade como questão da maior urgência".

34 I. MÉSZÁROS. Para Além do Capital, 2002, p. 1010. 
tradição crítica da filosofia ocidental (que István Mészáros identifica na "intenção crítica da dúvida metódica cartesiana" e na "luta de Bacon contra os 'Ídolos', passando pela programática 'revolução copernicana' da 'filosofia crítica' de Kant" e, finalmente, na 'negação negativamente autorreferida' de Hegel..." ${ }^{35}$ ) está na raiz do problema central relativo ao modo de conceber a relação entre conhecimento e ser: ao partir para um pensamento sem pressupostos, que abstrai de tudo para partir de alguma certeza segura, está-se fixando a atenção de tal forma no método que esmaece a necessária atenção a ser dispensada àquela relação (entre conhecimento e ser), de modo que o ser aparece já como expressão idealizada, como uma ontologia idealista, alheio ao mundo material.

Daí a diferença entre os modos hegeliano e marxista de conceber o enraizamento do conhecimento no processo de vida real. Em Marx o método surge do processo de vida real, não o contrário.

Não obstante a associação frequente feita entre o pensamento de $\mathrm{I}$. Mészáros e G. Lukács, é preciso pontuar uma importante crítica realizada por aquele à hipostasiação do método dialético neste. A crítica de Mészáros se apoia na recuperação do que há de mais genuíno no marxismo e na rejeição de um método que deixa de prestar contas ao ser, ao fundamento substantivo do próprio conhecimento em seu desenvolvimento real, e que, por isso, acaba lidando com a identidade entre conhecimento e ser como uma mera postulação abstrata.

Se Hegel teve o mérito de ter remetido as questões relativas ao emparelhamento entre ser e conhecimento às suas raízes num processo vital natural e histórico, Mészáros, seguindo a trilha da crítica marxista, radicaliza esta compreensão para criticar toda teoria que não preste contas ao ser, ao fundamento substantivo do próprio conhecimento em seu desenvolvimento histórico - e tal é o fundamento da autocrítica, uma "exigência fundamental da alternativa hegemônica historicamente sustentável à ordem sociometabólica do capital como um sistema orgânico"36. A lógica do ser é que determina uma lógica do pensamento, não havendo como preestabelecer uma lógica do pensamento independente do ser. É neste sentido que a dialética está enraizada no real, no próprio processo vital natural e histórico, devendo as contradições ser

35 I. MÉSZÁROS, Estrutura Social e Formas de Consciência, 2009, p.59.

36 Idem, p. 230. 
pesquisadas em cada expressão do ser, não havendo como constituir previamente um sistema aplicável a manifestações objetivas apenas teorizadas. Como se vê, é de central importância este reconhecimento para a adequada concepção do método.

Diante do cenário de crise estrutural do sistema sociometabólico do capital, István Mészáros propugna por uma alternativa hegemônica ao modo de controle metabólico social, a qual, "por não depender do objeto que nega, não se deixe restringir pela ordem existente, como sempre sucedeu no passado"37. Esta proposição se inspira na sua crítica ao modo como o sistema soviético se desenvolveu tendo como contraponto as potências capitalistas, a ponto de passar a "depender do objeto que nega" ao priorizar estrategicamente este contraponto ao invés de pautas emancipatórias que, ao contrário, eram duramente deixadas de lado em razão mesmo daquela dependência. Neste sentido é que se deve questionar se os direitos humanos poderiam ser vistos como uma alternativa hegemônica no presente, já que, prima facie, tais direitos dependem do objeto que negam. Ainda mais, tais direitos existem porque há este objeto, porque há o modo capitalista de produção hegemonicamente constituído, de modo que seu funcionamento parece estar sob estrito domínio da superestrutura jurídica totalizante e proeminente ${ }^{38}$. A perspectiva crítica que aponta este tipo de dependência parece ser insuficiente diante da insistência de movimentos sociais e mesmo de uma parte da crítica marxista com relação à questão dos direitos humanos.

Para István Mészáros,

"O nível de desenvolvimento atingido em nossa época torna possível a instituição de uma ordem social produtiva baseada na igualdade substantiva, contanto que essa ordem produtiva qualitativamente diferente seja planejada de forma consciente e gerida pelos produtores associados. Ao mesmo tempo, os antagonismos destrutivos e o desperdício catastrófico do anacronismo histórico irreversível do capital tornam a instituição desse tipo de controle social metabólico também necessária." ${ }^{39}$

37 I. MÉSZÁROS. Para Além do Capital, 2002, p. 21.

38 I. MÉSZÁROS. Estrutura Social e Formas de Consciência II, 2011, p. 94 e seguintes.

39 Idem, p. 148. 
Porém grandes desafios têm sido enfrentados no contexto atual no caminho em direção a este controle social.

Os desafios que o Estado de bem-estar social colocava para as classes trabalhadoras eram de grande magnitude, já que o aprofundamento das políticas de redistribuição de renda proporcionada pelo Welfare State esbarrava no modo de produção vigente, o qual, por sua natureza, tendia a colonizar todos os modos de intercâmbio de necessidades humanas. Estas tomam a forma de troca de mercadorias, inclusive quando por um curto período de tempo, num "canto do mundo", foram tratadas como "direitos" e como supostos requisitos elementares para a vida "civilizada". Talvez não se pudesse imaginar, diante de tais desafios, que um retrocesso histórico de grande magnitude atingiria as lutas dos trabalhadores no último quartel do século $X X$ e no início do século $X X I$.

Com profundas transformações no mundo do trabalho, com a emergência de novos processos de trabalho, com o avanço do desemprego estrutural e do trabalho precarizado ${ }^{40}$, houve uma degradação generalizada das pautas de direitos humanos nos movimentos sociais, com lutas cada vez mais defensivas diante da expansão das pautas neoliberais. Neste contexto, a crise afeta "tanto a materialidade da classe trabalhadora, a sua forma de ser, quanto a sua esfera mais propriamente subjetiva, política, ideológica, dos valores e do ideário que pautam suas ações práticas concretas" 41 . Com isto, se degradam a "estabilidade" viabilizada pelo Estado de bem-estar e a perspectiva de expansão para todos dos benefícios deste Estado social, explicitando os limites do sistema de reprodução do capital.

Explicita-se novamente o que apenas aparentemente era desmentido pelo desenvolvimento do Estado de bem-estar, que seja, que com o desenvolvimento industrial e produtivo, o trabalhador fica cada vez mais empobrecido, ou, no dizer de Marx, que quanto mais o trabalhador produz, menos ele tem em termos relativos: "o trabalhador se torna tanto mais pobre quanto mais riqueza produz" 42. Este o breve quadro no qual se dá a luta de classes na atualidade, a partir do qual

40 Sobre estes temas, vide R. ANTUNES. Adeus ao trabalho?, 1995, esp. pp. 23-46.

41 R. ANTUNES. As dimensões da crise no mundo do trabalho. In O Olho da História - Revista de História Contemporânea. N.ㄴ 4, disponível em http://www.oolhodahistoria.ufba.br/04antune. html, consulta em 17 de fevereiro de 2012.

42 K. MARX. Manuscritos Econômico-filosóficos, 2004, p. 80. 
se deve refletir sobre 0 modo como os sujeitos históricos do trabalho ${ }^{43}$ desenvolvem o discurso e a prática dos direitos humanos.

43 No contexto da fase descendente do capital fica claro que os sujeitos históricos do trabalho não são apenas aqueles envolvidos diretamente na produção industrial direta. Quando a produção é tomada pela relação $D-M-D$ ', todo aquele que não tem acesso direto às matérias primas e ao maquinário necessário para a produção viável é um sujeito histórico antagônico ao Capital - antagonismo este que nem sempre significará animosidade explícita, podendo mesmo haver uma convivência "pacífica" ou controlada entre capital e trabalho, como no curto período do Estado de bem-estar social na Europa. Os outros sujeitos históricos de que estamos a falar são os próprios trabalhadores desempregados, os trabalhadores precarizados e todos os grupos sociais que se organizam em torno das diversas lutas contra os imperativos do modo de reprodução sociometabólica do capital (lutas indígena, racial, de gênero, pela terra e assim por diante, evidenciados em movimentos como o zapatista no México, o dos piqueteiros argentinos e o MST no Brasil). Em suma, há um processo mais explícito de subsunção real de todos os grupos sociais à lei do valor, o que leva a clarear a conclusão de que as lutas precisam ser gerais, não restritas apenas a trabalhadores homens diretamente envolvidos na produção. Isto leva a um entrelaçamento da lei do valor com outras "leis de opressão", como a opressão contra a mulher e a opressão racial, que se reforçam mutuamente pela lei do valor. Deste entrelaçamento necessário, inclusive para a sustentabilidade das transformações sociais emancipatórias, decorre a importância das referidas lutas pontuais e específicas. 


\section{CAPÍTULO 2: SUPERESTRUTURA JURÍDICA E A TEORIA DAS MEDIAÇÕES}

István Mészáros, como Marx, não possui uma teoria sistemática sobre o direito. Mas alguns importantes textos seus tratam diretamente da questão da superestrutura jurídica e serão utilizados para amparar o presente estudo. Neste sentido, a metodologia utilizada é a de revisão bibliográfica, sendo que as fontes bibliográficas primárias, além de "Marxismo e Direitos Humanos", já referido, são "Legalidade, Moral e Educação" (em "A Teoria da Alienação em Marx"), "A liberação das mulheres: a questão da igualdade substantiva" (em "Para Além do Capital"), "Costume, tradição e lei expressa: limites históricos da superestrutura jurídica e política", "Transformação radical da superestrutura jurídica e política", "Aspectos-chave da mediação na dialética de base e superestrutura" (em "Estrutura Social e Formas de Consciência II") e "O desafio do desenvolvimento sustentável e a cultura da igualdade substantiva" (em "O Desafio e o Fardo do Tempo Histórico").

István Mészáros se ocupa especialmente, em suas duas últimas obras ${ }^{44}$, com a questão do "intercâmbio dialético entre as transformações materiais e as formas ideológicas", pois "é precisamente este intercâmbio dialético que estabelece os limites históricos gerais dentro dos quais o inevitável desafio para o fenecimento do Estado, por meio da transformação radical da superestrutura jurídica e política como um todo, deve ser encarado e realizado no devido tempo" ${ }^{\text {45 }}$. Para o que interessa neste trabalho, é preciso localizar o direito e sua teoria como um aspecto da superestrutura existente no contexto do controle sociometabólico do capital, como a superestrutura jurídica necessária a este controle. Trata-se de uma forma ideológica que está em intercâmbio dialético com as transformações materiais visadas e por isso é um aspecto a ser necessariamente levado em conta num projeto que tenha em vista o fenecimento do Estado e do sistema do capital.

44 Quais sejam, Estrutura Social e Formas de Consciência - A Determinação social do método, 2009, e Estrutura Social e Formas de Consciência II - A Dialética da Estrutura e da História, 2011.

45 I. MÉSZÁROS. Estrutura Social e Formas de Consciência II, 2011, p. 149. 
A relação entre a superestrutura e a base material da sociedade "é, em última análise, determinada pelo imperativo absoluto da dominação estrutural permanente, a todo custo, do trabalho" ${ }^{46}$.Em razão de tal imperativo, historicamente posto, o intercâmbio entre trabalho e capital aparece como insuperavelmente antagônico ${ }^{47}$, como exploração de uma classe pela outra, exploração que ao mesmo tempo revela a interdependência entre capital e trabalho abstrato, os quais se alimentam mutuamente, o trabalho abstrato como pressuposto do capital e este como pressuposto daquele. Ao se referir à "dominação estrutural permanente", Mészáros remete justamente a esta interdependência, a qual, na medida em que se impõe historicamente, submete, potencialmente, todo trabalho humano aos imperativos da reprodução do capital.

$\mathrm{Na}$ sociedade capitalista, a satisfação das necessidades humanas, que se dão necessariamente pela mediação entre o ser humano e a natureza, passa a ser condicionada a mediações de segunda ordem imperativas à reprodução social do capital. Estas mediações aparecem na medida em que nenhuma reprodução societal continuada é concebível sem suas mediações específicas ${ }^{48}$. Este aparecimento se dá num contexto de abundância material e se desenvolve apoiada na expansão das próprias necessidades humanas. Esta expansão, por outro lado, é guiada pelos imperativos próprios da reprodução do capital, de modo que a satisfação de necessidades se põe como um horizonte sempre inalcançável, ou sempre "expansível" para atender aos imperativos de reprodução continuada do capital.

Neste mesmo contexto, a relação entre a superestrutura e a base material é, em última análise, determinada pelo imperativo da dominação do capital, mas "a relação entre a superestrutura e a base material da sociedade é muito mais ampla do que a forma como a encontramos articulada sob as circunstâncias históricas específicas do modo de reprodução societal do capital" ${ }^{\prime 9}$.

Neste ponto, István Mészáros amplia a análise empreendida por Karl Marx no prefácio de 1859 da "Contribuição à Crítica da Economia Política". Neste texto, o filósofo alemão se ateve à análise da relação entre base e superestrutura no

\footnotetext{
46 Idem, p. 123.

47 Idem, p. 124.

48 Idem.

49 Idem, p. 125.
} 
nível das mediações de segunda ordem e do imperativo da dominação do capital. De fato, segundo Mészáros, esta relação entre a superestrutura e a base material foi avaliada de forma concisa por Marx, "com referência ao modo de reprodução societal do capital" ${ }^{\prime \prime}$. Ao se referir a uma avaliação concisa de Marx, Mészáros passa a explorar detalhes e repercussões de tal avaliação para uma teoria da transição, objeto específico de preocupação deste último autor.

De fato, para Mészáros, "nenhuma relação de reprodução societal continuada é concebível sem seu próprio tipo de mediação dos intercâmbios entre os seres humanos e a natureza, de um lado, e entre os indivíduos sociais entre si, bem como entre os grupos aos quais pertencem, de outro" ${ }^{51}$. A mediação, em si, não representa um problema, se tratando, ao contrário de algo essencial ao ser humano, porque é sempre mediada a relação deste com a natureza, com os indivíduos e com os grupos sociais aos quais pertencem.

O problema "surge do caráter historicamente específico dos tipos de mediação que são inseparáveis do modo de reprodução social metabólica do capital" ${ }^{\prime 52}$. Tais mediações, que são as mediações de segunda ordem antagônicas, tornam-se uma ameaça ainda maior na medida em que a tendência à dominação global e o impulso expansionista irrefreável do capital levam a um esgotamento da própria natureza. A dominação do capital, assim, embora mundializada, passa a mostrar-se produtivamente inviável (pois impõe lógicas de consumismo e de exclusão social) e historicamente insustentável (pois tende a esgotar os recursos naturais disponíveis à vida humana).

Assim, no que tange ao cerne do presente capítulo, o ponto a ser ressaltado é que, para István Mészáros, "a relação entre a superestrutura e a base material da sociedade é muito mais ampla do que a forma como a encontramos articulada sob as circunstâncias históricas específicas do modo de reprodução societal do capital" ${ }^{153}$. Esta análise estaria apoiada nas concepções marxistas, desenvolvidas de forma concisa no prefácio da "Contribuição à Crítica da Economia Política", já que, segundo Mészáros,

\footnotetext{
50 Idem, p. 123.

51 Idem, p. 124.

52 Idem.

53 Idem, p. 125.
} 
"de acordo com Marx, a 'superestrutura', em seu sentido primordial, é radicalmente diferente da superestrutura articulada como 'superestrutura jurídica e política'... Pois ela continua sendo o constituinte estrutural e ontologicamente fundamental, não obstante a posição dominante da lei e da política ao longo da história das sociedades de classe" ${ }^{" 54}$.

Esta concepção está intimamente ligada com o que se pode chamar de teoria das mediações, a qual se ampara numa perspectiva ontológica. A superestrutura é um "constituinte estrutural e ontologicamente fundamental", cujos problemas não se enfrentam apenas na base da crítica destrutiva e da denúncia, sem a necessidade de qualquer perspectiva propositiva. Assim, trata-se de uma mediação primária, pois nada mais é do que o conjunto de concepções e teorias de que se vale o ser humano na sua relação em geral com a natureza. A organização das ideais no cérebro humano é uma mediação primária, necessária para a vida humana.

Disto decorre que os problemas a serem enfrentados para a superação do sistema social excludente dizem respeito às mediações de segunda ordem, enquanto negatividade, mas também às mediações primárias, que devem ser levadas em conta na formulação positiva de uma alternativa a tal sistema. Assim, surge a necessidade de traçar uma linha de demarcação entre a "superestrutura ontologicamente intranscendível" e a "superestrutura jurídica e política", pois esta linha 'torna possível o 'fenecimento' do Estado e o fim da dominação da vida social por parte da legalidade separada e da normatividade abstrata" ${ }^{25}$.

Esta teoria das mediações, que está bem maturada no pensamento de István Mészáros, nada mais é do que a generalização da leitura de K. Marx sobre o desenvolvimento histórico dialético da sociedade no contexto do capitalismo, que este autor elaborou com sua teoria do valor, desenvolvida como crítica às concepções teóricas da economia política de seu tempo. Naquela teoria, o valor de uso de um bem decorre da sua utilidade para o ser humano na sua interrelação com a natureza, inter-relação que se dá na busca pela satisfação de necessidades naturais e históricas, enquanto o valor de troca é a propriedade das mercadorias que se trocam entre si num determinado contexto das relações de

54 Idem, p. 103.

55 Idem. 
produção e das trocas de mercadorias. Estes conceitos, desenvolvidos no âmbito do estudo da economia política, passam a ser examinados por Marx em sua relação dialética entre utilidade e trocabilidade. A dialética do real indica que em outros âmbitos teóricos aparecem relações semelhantes entre determinações históricas particulares e determinações originárias decorrentes da relação necessária entre ser humano e natureza - daí a distinção entre mediações de segunda ordem (existentes no contexto das relações de produção capitalistas) e mediações de primeira ordem (necessárias em qualquer ordem reprodutiva atualmente concebível), que tem o condão de explicitar a dialética existente nos mais diversos campos da "produção humana" 56 .

Esta perspectiva ressalta, assim, que as alternativas à ordem vigente devem ser gestadas no seio da sociedade existente (com o combate às mediações de segunda ordem) e levando-se em conta o modo específico e intranscendível da relação entre o ser humano e a natureza (com a formulação de alternativas que se apoiem nas mediações primárias ${ }^{57}$. Outro modo de encarar o problema poderia levar à conclusão de que não há alternativa alguma, seja porque as mediações de segunda ordem não podem ser superadas (esta a perspectiva conservadora que rejeita a historicidade da estrutura social), seja

56 "Produção" tomada aqui não apenas no sentido econômico, mas no sentido da produção em geral, pelo ser humano, de suas condições de vida, que envolve os produtos da atividade espiritual, da atividade econômica, da atividade social, etc (T. BOTTOMORE, A dictionary of marxist thought, 1991, p. 13), todas sujeitas à alienação. Nas diversas formas, o ser humano separa os produtos da sua atividade em um mundo de objetos exteriores dotados de poder e a eles se submete, deles se torna dependente. Com isso, ele se aliena não apenas do produto da sua atividade, mas da própria atividade e da natureza (T. BOTTOMORE, $A$ dictionary of marxist thought, 1991, p. 13). Ao contrário do que poderia decorrer de concepções reducionistas do marxismo, que solapam das mais diversas formas o alcance do sistema de Marx, é preciso compreender que o conceito chave de "atividade humana produtiva" "nunca significa simplesmente 'produção econômica"' $\square$ (I. MÉSZÁROS. A Teoria da Alienação em Marx, 2006, p. 108). Em Marx, se a economia "é o 'determinante último', é também um 'determinante determinado': ela não existe fora do complexo sempre concreto e historicamente mutável de mediações concretas, inclusive as mais 'espirituais"' (I. MÉSZÁROS. A Teoria da Alienação em Marx, 2006, p. 108 ). Neste mesmo sentido, referindo-se porém à categoria correlata "troca", como afirmado por G. DUMÉNIL, M. LÖWY, E. RENALT. Lire Marx, 2009, p. 107, em Marx, "o termo troca designa a um só tempo a interação entre indivíduos em geral (tanto as 'trocas materiais', com as 'trocas espirituais') e a maneira pela qual a interação se realiza na atividade produtiva sob a forma de 'cooperação' (Zusammenwirken) e na troca de produtos do trabalho".

57 Os combates são antes gestados na prática real de movimentos sociais do que na teoria - à teoria cabe captar tais combates e oferecer reflexões que contribuam para uma práxis revolucionária. 
porque o único meio de superar tais mediações seria por meio de sua completa "abolição", ao invés de sua superação (esta a perspectiva utópica que sobrevaloriza a historicidade ao ler contextos mais restritos das lutas sociais pela lente da história de longo alcance). De fato, estas leituras desprezam o real significado das mediações primárias, as "mediações necessárias para todas as formas viáveis de reprodução", cujo contraste com "as antagônicas mediações de segunda ordem é absolutamente impressionante" ${ }^{\prime 58}$. Tal desprezo se dá seja pela identificação eternizante das mediações secundárias com as mediações primárias, atribuindo àquelas um estatuto de instranscendibilidade, seja pela identificação ingênua das mediações secundárias com as mediações primárias, atribuindo a estas um estatuto de transcendibilidade.

Estas mediações primárias são, segundo István Mészáros:

- "a regulação necessária, mais ou menos espontânea, da atividade biológica reprodutiva e o tamanho da população sustentável, em conjunto com os recursos disponíveis;

- a regulação do processo de trabalho por meio do qual o necessário intercâmbio da comunidade com a natureza possa produzir os bens necessários para a satisfação humana, como também as ferramentas de trabalho, empreendimentos produtivos e conhecimento apropriados pelos quais o próprio processo reprodutivo passa a ser mantido e aprimorado;

- o estabelecimento de relações de troca adequadas sob as quais as necessidade historicamente cambiantes dos seres humanos possam ser interligadas com o propósito de otimizar os recursos naturais e produtivos disponíveis incluindo os culturalmente produtivos;

- a organização, a coordenação e o controle da multiplicidade de atividades por meio das quais as exigências materiais e culturais do processo de reprodução sociometabólico bem-sucedido de comunidades humanas progressivamente mais complexas possam ser asseguradas e protegidas;

- a alocação racional de recursos materiais e humanos disponíveis, lutando contra a tirania da escassez por meio da utilização econômica (no sentido de economizar) dos modos e meios de reprodução da sociedade dada, na medida do viável sobre a base de um nível de produtividade alcançável e dentro dos limites das estruturas socioeconômicas estabelecidas;

- e a promulgação e administração de regras e regulamentos

58 I. MÉSZÁROS. Estrutura Social e Formas de Consciência, 2009, p. 192. 
da sociedade dada como um todo, em conjunção com outras funções e determinações primárias mediadoras." 59

A primeira das mediações primárias apontadas parece, numa primeira leitura, bastante problemática, podendo até mesmo conduzir a certo malthusianismo. Qual o seu significado? O problema do crescimento da população em István Mészáros não aparece gratuitamente. De fato, o crescimento da população é sempre sujeito a acontecimentos sociais e naturais. Ao que parece, István Mészáros se preocupa com que também este fenômeno esteja sob controle consciente da humanidade, controle que deveria ser "mais ou menos espontâneo".

O crescimento da população é, em geral, não regulado, embora sujeito a uma série de condições econômicas, a acontecimentos como guerras, exploração desmedida e exclusão social. Poder-se-ia dizer que não é realizada de forma racional. As explosões populacionais só são possíveis com crescimentos vertiginosos da produtividade e da produção, sendo que as crises de produção podem levar a uma diminuição drástica e incontrolável (por guerras, exclusões, matanças, etc) das populações. Tais preocupações estiveram de certo modo presentes no pensamento de Thomas Malthus, que propunha um controle de natalidade em razão de vislumbrar um crescimento geométrico da população, prevendo que a falta de regulação geraria a fome, pois a produção de alimentos poderia apenas crescer aritmeticamente (isto é, linearmente, enquanto a população cresceria exponencialmente, portanto muito mais rápido). Tais preocupações também estão envolvidas em políticas de planejamento familiar de cunho liberal-social, nas quais se busca contribuir para o esclarecimento e para a possibilidade da escolha, pelos indivíduos, do número de filhos que querem ter. Tais políticas não envolvem um "malthusianismo" na medida em que não ocasionem medidas antilibertárias e anti-igualitárias. O grande desafio está justamente em saber como fazer isto, mas István Mészáros não explicita o que seria uma "regulação necessária, mais ou menos espontânea, da atividade biológica reprodutiva e o tamanho da população sustentável”, o que é bastante problemático.

De qualquer modo, segundo, István Mészáros, todas as mediações 
primárias não poderiam ser desprezadas num projeto de transformação. Tal projeto de transformação deveria envolver também "a mais ativa contribuição por parte da superestrutura para a realização do objetivo almejado" ${ }^{60}$, com a busca pela superação da preponderância da superestrutura jurídica e política existente no contexto atual. Esta ativa contribuição não poderia ser desprezada, tendo em vista a normatividade direta decorrente de algumas das mediações primárias, como a "regulação do processo de trabalho", a "a organização, a coordenação e o controle da multiplicidade de atividades" e a própria "alocação racional de recursos materiais e humanos disponíveis", para não citar as mediações diretamente normativas nas necessárias "promulgação e administração de regras e regulamentos da sociedade dada como um todo".

Isto tudo é inseparável da "preocupação com o necessário 'fenecimento do Estado"', e consequentemente da específica superestrutura jurídica, já que, no contexto atual da fase descendente do desenvolvimento do capital, esta apenas tende a reforçar o círculo vicioso da destrutividade e insustentabilidade sistêmicas. Com isso, Mészáros combate aqueles movimentos sociais que acabaram por abandonar a finalidade do fenecimento do Estado, os quais, "ao voltar as costas para a difícil tarefa de fazer sua requerida contribuição ao 'fenecimento do Estado', por qualquer motivo... abandonam ao mesmo tempo sabidamente ou não - o projeto estratégico marxiano engajado na transformação socialista da sociedade" ${ }^{16}$. Ao mesmo tempo, esclarece que o revolucionamento da base material necessita que a superestrutura seja também revolucionada, e 0 nível em que tais preocupações devem se inserir é o das mediações primárias, não de forma idealizada, mas como uma concepção revolucionária a acompanhar o processo de revolucionamento material.

Neste sentido, a libertação das mediações de segunda ordem tem relação direta com a superação da superestrutura jurídica e política. A questão relevante neste terreno é a superação

"da tirania desumanizadora da base material, tal como manifesta sob o domínio do capital, e não a remoção fictícia das distintas características e determinações da materialidade em si da vida dos seres humanos (que são e devem sempre

60 I. MÉSZÁROS. Estrutura Social e Formas de Consciência II, 2011, p. 138.

61 Idem. 
continuar sendo, uma parte integrante da natureza - ainda que uma parte unicamente automediadora e, com isso, potencialmente autolibertadora em seu sentido genuíno)"62.

A equiparação da superestrutura jurídica e política com a "superestrutura enquanto tal" apenas poderia servir a propósitos anti-históricos, em desprezo à perspectiva trans-histórica que leva em conta as necessárias mediações sociometabólicas. Tal equiparação, seja decorrente de perspectivas conservadoras ou de utópicas, despreza as necessárias "promulgação e administração de regras e regulamentos da sociedade dada como um todo".

Observar-se, assim, que o que está em questão, acerca da superestrutura, no âmbito das preocupações com uma teoria da transição, é alcançar as práticas materiais primordiais e necessárias, para que se possam conceber, com o revolucionamento da base, as correspondentes práticas reguladoras e superestruturais dos "produtores livremente associados".

Restringindo a análise à superestrutura jurídica, conforme o objeto do presente trabalho, não é que a solução para a questão da alienação jurídica seja meramente a "luta política". Tal solução remete circularmente de um problema a outro, pois a superestrutura política possui suas próprias contradições e conflitualidades, apresentando também potencialidades emancipatórias que contrastam com suas instituições separadas e abstratas, como se vê na dinâmica dos partidos socialistas e trabalhistas que se tornam partidos parlamentares ${ }^{63}$, e com práticas restringidas de acordo com os imperativos do sistema sociometabólico do capital. Não obstante a visão de totalidade que deve apoiar uma perspectiva crítica de análise, frequentemente a assertiva de que se deve buscar na luta política soluções para as questões jurídicas são um meio pelo qual

62 Idem, p. 126, onde arremata, para fundamentar seu argumento, que Marx sempre "insistiu... na necessidade de se reconhecer as determinações objetivas que deve ser respeitadas em todas as questões humanas".

63 I. MÉSZÁROS. O Desafio e o Fardo do Tempo Histórico, 2007, p. 276 e seguintes, discute a questão da alternativa ao parlamentarismo e assevera que "alguns dos partidos mais importantes, bem como bem-sucedidos, do ponto de vista eleitoral, da esquerda radical, constituídos no interior da estrutura da Terceira Internacional, em condenação impetuosa e explícita do fracasso histórico irreparável da Segunda Internacional Socialdemocrata, seguiram - dessa vez realmente no devido tempo - o mesmo caminho desastroso dos partidos que implacavelmente denunciaram e descartaram. Neste sentido, basta pensar na 'via parlamentar ao socialismo' que os partidos comunistas italiano e francês seguiram". 
(voluntária ou involuntariamente) se deixa de examinar com o devido rigor os problemas da superestrutura jurídica.

István Mészáros trata esta questão de modo muito direto:

\begin{abstract}
"Claramente, no entanto, isso está muito longe de ser simplesmente uma questão política, apesar das preconcepções sectárias reducionistas e, em última análise, autoderrotistas defendidas nesse sentido. A ênfase exclusivista na política, ao custo das estratégias muito mais amplas de transformação estruturalmente viável a ser historicamente sustentada em todos os domínios reprodutivos, não pode ser uma abordagem viável a essas questões, não importa quão importante seja o papel que a intervenção política radical deva inicialmente desempenhar no processo emancipatório geral, especialmente na época de ruptura com a pressão da política alienada sobre a mudança societal."
\end{abstract}

A crítica de István Mészáros está claramente dirigida às ilusões de abordagens tradicionais dos sujeitos do trabalho, que tiveram na revolução russa de 1917 o paradigma da tomada do poder, sem levar em conta as "tragédias e malogros" do tipo de desenvolvimento instituído "logo após a conquista do poder por Lênin e seus seguidores"65, o qual não logrou superar o sistema sociometabólico do capital, mas apenas a forma especificamente capitalista deste. A defesa de uma transformação ampla estruturalmente viável passa pela crítica à ênfase exclusivista na política, fomentada por décadas pelo poder orientador do paradigma da revolução russa, o qual foi definitivamente após décadas de repressão e opressão estatal, mesmo porque os desenvolvimentos do socialismo real, verbis:

"só puderam sublinhar dolorosamente que, como coloca Marx, a forma econômica específica pela qual o trabalho excedente não pago é sugado dos produtores diretos determina a relação dos governantes e governados, já que ela emerge diretamente da própria produção e, por sua vez, reage sobre ela como elemento determinante (Marx, O Capital, vol. 3, p. 772).

Nesse sentido, as razões para o trágico fracasso histórico de mais de sete décadas de poder soviético devem ser buscadas, para que sejam evitadas no futuro, tanto na modalidade

64 I. MÉSZÁROS. Estrutura Social e Formas de Consciência II, 2011, p. 136.

65 I. MÉSZÁROS. Para Além do Capital, 2002, p. 351. 
experimentada de "sugar o trabalho excedente não pago dos produtores diretos" como na dura realidade do historicamente conhecido Estado pós-revolucionário como 'elemento determinante'. Este, ao invés de liberar as forças de tomada de decisão autônomas, pelas quais, no devido tempo, o Estado poderia 'fenecer', impôs implacavelmente à sociedade 0 sistema do capital pós-capitalista de extração do trabalho excedente, perpetuando, com consequências desastrosas, uma 'relação de governantes e governados"'66.

Assim, as preocupações sobre a transformação da sociedade devem igualmente ocupar-se da superação da superestrutura jurídica, evitando a "ênfase exclusivista na política" e as perspectivas que desprezam as mediações de primeira ordem e a superestrutura enquanto tal. Caso se quisesse apontar alguma "centralidade" para a transformação estruturalmente viável, não seria a superestrutura enquanto tal que cumpriria este papel, mas desprezá-la seria um equívoco se se busca a viabilidade e a sustentabilidade das transformações requeridas.

Deve-se definir, assim, uma "prática crítica", algo que envolve tanto a negatividade da crítica, quanto a positividade de uma prática de luta. Estes dois aspectos são inseparáveis. Neste ponto, cabe enfatizar a advertência de István Mészáros no sentido de que o projeto socialista não pode se definir "simplesmente nos termos de dizer não ao controle sistêmico do capital", pois tal projeto "não pode constituir uma alternativa viável... a não ser que seja com sucesso e articulado de maneira positiva... com seu próprio tipo de reciprocidade baseada na automediação consciente de seus indivíduos sociais" 67 .

O novo tipo de causalidade imposta pelo ser humano sobre si mesmo no contexto do capitalismo não deixa de ser uma necessidade histórica e, por isso, uma "necessidade evanescente", não podendo ser identificada com a causalidade natural. Ao mesmo tempo, ela não é "de modo algum inteligível sem que se centre atenção no mais ativo papel da superestrutura em mutação em sua constituição e renovada afirmação", sendo que

"a solução historicamente factível para esse desafio é trazer sob controle a necessidade autoimposta em questão, pela superação [overcoming] das mediações de segunda ordem

66 Idem, p. 514.

67 I. MÉSZÁROS. Estrutura Social e Formas de Consciência II, 2011, p. 140. 
antagônicas do sistema do capital por meio de uma alternativa automediada - porque conscientemente autogerida. Naturalmente, o papel emancipatório potencial da superestrutura qualitativamente reconstituída não poderia ser maior nesse sentido" ${ }^{\text {. }}$.

Este "papel emancipatório potencial da superestrutura qualitativamente reconstituída" só pode aparecer a partir de um exame das lutas sociais concretas, discernindo nelas as práticas que são a base para a reconstituição da superestrutura.

Vê-se que Mészáros permanece num nível elevado de abstração, mas não deixa, com isso, de abrir caminho para que uma perspectiva crítica positiva adentre em muitos campos para os quais ela tem permanecido estranha, inclusive o da superestrutura jurídica, pela teoria crítica do direito. É dizer, a finalidade da análise critica da superestrutura jurídica, e em específico dos direitos humanos, é, assim, oferecer a devida interpretação do que seria a "superestrutura qualitativamente reconstituída". Tal deve ser alcançado pelo exame da prática e dos discursos dos sujeitos históricos do trabalho sobre os tais direitos humanos. Tudo isto tendo por pressuposto a amplitude da relação entre a superestrutura e a base material da sociedade, que não se restringe àquela constatada nas circunstâncias históricas específicas do contexto capitalista.

O intercâmbio dialético entre as transformações materiais e as formas ideológicas não pode ser entendido como um movimento unilateral, mesmo porque não existe uma correspondência mecânica entre a base e as ideias, mas sim uma "inter-relação tripla característica desse" intercâmbio. Nesta inter-relação estariam, primeiro,

\begin{abstract}
"as 'relações de produção' que constituem 'a estrutura econômica da sociedade, a base real'. Segundo, sobre essa base real 'se eleva uma superestrutura jurídica e política'. E o terceiro fator essencial é constituído pela múltipla variedade das 'formas ideológicas' que entram em cena como 'formas sociais determinadas de consciência' e, como tais, 'correspondem à superestrutura jurídica e política'"'69.
\end{abstract}

68 Idem.

69 Idem, p. 127, citando as formulações de Marx no Prefácio de 1859 da Contribuição à crítica 
Ou seja, István Mészáros desenvolve a caracterização marxiana do complexo base e superestrutura para conceber um complexo de três níveis, formado por base, superestrutura jurídica e política e formas ideológicas correspondentes a esta. Este desenvolvimento está inspirado no Prefácio de 1859 à "Contribuição à Crítica da Economia Política", no qual Marx afirma:

"na produção social da própria existência os homens entram em relações determinadas, necessárias, independentes de sua vontade; essas relações de produção correspondem a um grau determinado de desenvolvimento de suas forças produtivas materiais. A totalidade dessas relações de produção constitui a estrutura econômica da sociedade, a base real sobre a qual se eleva uma superestrutura jurídica e política e à qual correspondem formas sociais determinadas de consciência" ${ }^{\prime 0}$.

A partir deste trecho se percebe, como observa István Mészáros, que os termos de referência de Marx são mais complexos do que se supõe tradicionalmente, suposição tradicional esta que se apoia na clássica passagem de Marx, no mesmo texto, de que "não é a consciência dos homens que determina o seu ser, mas, inversamente, o seu ser social que determina a sua consciência". Esta suposição levaria à conclusão de que a superestrutura é um reflexo da base material, um tipo de "vapor" da base sólida da realidade. Uma leitura do texto completo de Marx afasta este tipo de interpretação, pois é o próprio Marx que se refere a que "a transformação que se produziu na base econômica transforma mais ou menos lenta ou rapidamente toda a colossal superestrutura" ${ }^{71}$. Não se poderia conceber esta defasagem se se defendesse a tese da superestrutura como mero "reflexo" da base.

Comentando o mesmo referido Prefácio, István Mészáros entende que uma leitura atenta deixa claro os objetivos de Marx:

"1. focar-se na distinção em si, enfatizando a importância vital de manter constantemente em mente as diferenças qualitativas nela implícitas.

2. insistir que a superestrutura não pode ser determinada com a

da Economia Política.

70 K. MARX, Prefácio de 1859 da Contribuição à crítica da Economia Política, 2008, p. 47-8, apud I. MÉSZÁROS. Estrutura Social e Formas de Consciência II, 2011, p. 39.

71 Idem. 
mesma precisão que a estrita 'transformação material das condições econômicas de produção';

3. indicar como há uma interação dialética entre a superestrutura e a base material - e que, portanto, ambas afetam uma à outra de maneira profunda, assim constituindo conjuntamente um todo orgânico -, por implicação: o desenvolvimento geral de todo o complexo não pode ser 'verificado fielmente com a ajuda das ciências físicas e naturais'.

De modo estranho, no entanto, a passagem é interpretada como se Marx tivesse dito: 'convém nunca distinguir entre a transformação material das condições econômicas de produção e as formas ideológicas'”.

Esta interação dialética entre base e superestrutura está muito longe das grosseiras caracterizações do marxismo como a "teoria segundo a qual a economia determina todo o ser humano social, etc". Para Mészáros, ao contrário, que se apoia na leitura de Marx, "o Estado não só foi moldado pelos fundamentos econômicos da sociedade, mas ele também foi moldando da maneira mais ativa a realidade multifacetada das manifestações reprodutivas do capital no decorrer de suas transformações históricas"72. Daí se poder falar num papel ativo da superestrutura jurídica e política num dado contexto histórico, o que será objeto de mais detida consideração no capítulo 6 deste trabalho.

Segundo Karl Marx, "as ideias da classe dominante são, em cada época, as ideias dominantes"73, mas, como lembra István Mészáros, "o controle da produção intelectual pela classe dominante, não importa quão poderosa possa ser sob determinadas circunstâncias sócio-históricas em termos materiais e políticos, não pode nunca ser absoluto", em razão das "tendências objetivamente em desdobramento da transformação histórica"74. Ou seja, o domínio de classe tanto não é absoluto na base, como não é absoluto na superestrutura, e tais aspectos estão inter-relacionados, daí o intercâmbio que se estabelece entre as transformações materiais e as formas ideológicas.

Neste sentido também, o controle da superestrutura jurídica não é absoluto, não o é justamente em razão do intercâmbio inevitável desta

72 I. MÉSZÁROS. Estrutura Social e Formas de Consciência II, 2011, p. 149.

73 K. MARX, F. ENGELS. A Ideologia Alemã, 2007, p. 47.

74 I. MÉSZÁROS. Estrutura Social e Formas de Consciência II, 2011, p. 148. 
superestrutura com a base material, o qual põe em movimento tendências de transformação histórica, na medida em que a base material não é um todo homogêneo.

Daí que os sujeitos sociais do trabalho se relacionem com as "concepções dominantes" do direito não como meros sujeitos "manipulados", "dominados", mas estabelecendo uma relação conflitiva com tais concepções, como se vê nas formas de discurso destes sujeitos sobre os direitos humanos. Tais discursos não são meras reproduções dos esquemas impostos pela superestrutura jurídica existente. Assim, se, por um lado, os direitos humanos são uma das expressões da superestrutura jurídica, esta não conforma toda a categoria "direitos humanos" tal qual ela aparece atualmente. A completa caracterização de tal categoria exige a verificação do intercâmbio dialético existente na tripla inter-relação estre base e formas de consciência.

Neste sentido é importante a mencionada conceituação da inter-relação tripla, a qual serve para distinguir o modo pelo qual a superestrutura jurídica e política se torna dominante, colonizando e subordinando todas as formas ideológicas no período atual. Esta distinção permite vislumbrar com maior rigor a tendência à juridicização das relações sociais, a que István Mészáros se refere como a tendência da superestrutura jurídica e política em "adquirir uma preponderância amplamente penetrante" ${ }^{\prime 75}$. Esta tendência teve um impacto diferenciado nas duas fases do sistema do capital: na ascendente foi essencial para a expansão material, pois o Estado oferecia a dimensão coesiva ausente na centrifugalidade do mercado ${ }^{76}$; e na descendente, na qual há um papel mais ativo e até autoritário do Estado, essencial para manter o sistema sociometabólico vigente, mesmo com todo o desperdício e a destrutividade inerente a ele.

Com esta juridicização, "os vários discursos práticos sem os quais a reprodução societal não poderia de modo algum funcionar estão agora intimamente ligados às, e profundamente afetados pelas, determinações esmagadoras da superestrutura jurídica e política". Por isso, Mészáros conclui que "a causa da emancipação humana inevitavelmente requer também a

75 Idem, p. 153.

76 Daí a afirmação de que "O desenvolvimento do sistema do capital foi um avanço histórico que seria inconcebível sem a contribuição maciça da superestrutura jurídica e política para com as determinações estruturais que a tudo abrangem do sistema como um todo". Idem. 
liberação dos vários discursos práticos das severas limitações impostas sobre eles, tendo como base os interesses próprios do capital, por parte da cada vez mais preponderante superestrutura jurídica e política em $\mathrm{si}^{\text {"77}}$.

O papel crescentemente negativo da superestrutura jurídica e política em si é vista por István Mészáros como "extremamente perigoso". Este crescimento da negatividade explica-se pela dialética histórica objetiva "entre as necessidades internas da base material do capital e as condições jurídicas e políticas requeridas, sob as quais as potencialidades do sistema puderam ser transformadas em realidade", não pelo "fantasioso trabalho cerebral de 'juristas ocidentais' circularmente projetado por Max Weber" ${ }^{\prime 78}$. Os desafios dos sujeitos do trabalho neste contexto de crescimento do papel negativo da superestrutura jurídica são também crescentes. Daí a importância de um exame crítico adequado desta superestrutura e das alternativas propostas pelos movimentos sociais envolvidos nas tendências objetivamente em desdobramento da transformação histórica.

No que tange à relação entre as mediações de primeira e segunda ordem, é importante pontuar a distinção entre o histórico e o trans-histórico. Mészáros enfatiza que as determinações estruturalmente primárias não devem ser subestimadas, ou

"em outras palavras, não deveríamos desconsiderar a realidade duradoura tanto da base material quanto da correspondente superestrutura nessas equações, atribuindo um papel efêmero à segunda a partir da compreensão errônea de sua definição como superestrutura. Pois, devido à efetividade de sua constituição e aos seus necessários intercâmbios dialéticos contínuos, nem a base material da reprodução societal, nem a superestrutura enquanto tal podem ser conceitualizadas como historicamente superadas [superseded] numa base permanente em algum ponto futuro do desenvolvimento" ${ }^{\prime 7}$.

77 Idem, p. 154. De forma que poderia parecer surpreendente, István Mészáros coloca entre estes discursos práticos até mesmo o discurso religioso, afirmando que "o mesmo vale não só para a necessidade de emancipar o discurso moral, político e estético de sua dominação por parte das determinações imperativas do Estado, mas também para o discurso religioso e para a Teologia da Libertação".

78 Idem, p. 166.

79 Idem, p. 135. 
A "realidade insuperável da superestrutura em si", que mantém uma "correlação dialética ao sempre necessário fundamento do processo de reprodução societal", não pode ser equiparada, como já observado, com a superestrutura jurídica e política, a não ser em desprezo à perspectiva transhistórica que leva em conta as necessárias mediações sociometabólicas (mediações de primeira ordem). Esta diferenciação tem importância crucial na avaliação das alternativas da transformação social, e sem ela "não poderia haver nenhuma forma de superar [overcoming] a 'jaula de ferro' do sistema do capital"

Daí a já referida preocupação "com toda a complexidade da reprodução societal", o que envolve a reestruturação não só dos "pré-requisitos materiais elementares do processo de trabalho", mas também os "mais mediados intercâmbios reguladores no domínio da consciência social e a produção emancipatória de ideias, incluindo a mudança qualitativa da hoje dominante modalidade de normatividade externamente imposta para a avaliação internamente adotada e positivamente buscada dos objetivos conscientemente escolhidos pelos indivíduos" $"$.

Esta posição de István Mészáros mostra que o que está em jogo não é a superação da normatividade enquanto tal, pois esta não poderia ser superada em qualquer estrutura reprodutiva concebível atualmente. Trata-se, isto sim, de buscar uma modalidade interna de normatividade, qualitativamente diferente porque modelada pelos indivíduos num parâmetro de autodeterminação interna. Esta se contrapõe à legalidade externa ${ }^{82}$, característica e necessária à reprodução social capitalista, avessa à normatividade interna modelada pelos indivíduos.

Por isso "o papel da superestrutura é muito importante na contribuição para o resultado futuro. É nesse contexto que o significado transformador potencial da superestrutura enquanto tal se torna claramente visível também com respeito à instituição de um futuro radicalmente diferente" ${ }^{\prime 3}$. Para compreender esta

\footnotetext{
80 Idem, p. 136.

81 Idem.

82 A respeito deste assunto, vide I. MÉSZÁROS. A Teoria da Alienação em Marx, 2006, p. 170 e ss..

83 I. MÉSZÁROS. Estrutura Social e Formas de Consciência II, 2011, p. 136.
} 
afirmação não se pode confundir superestrutura jurídica e política com a superestrutura enquanto tal. E quanto ao papel da superestrutura para o resultado futuro das lutas sociais, deve-se atentar para que é a prática dos próprios sujeitos do trabalho que pode apontar qual a superestrutura alternativa adequada, não havendo uma predefinição sobre quais sejam as características desta. 


\section{PARTE II - A CRÍTICA AOS DIREITOS HUMANOS: UMA METODOLOGIA MATERIALISTA HISTÓRICA A PARTIR DA LEITURA DE ISTVÁN MÉSZÁROS}

\section{CAPÍTULO 3: "DIREITOS DO HOMEM": NEGATIVIDADE E POSITIVIDADE DA CRÍTICA.}

O pensamento marxista é um amplo conjunto de crítica à filosofia, às ciências sociais e à sociedade capitalista, cujas raízes teóricas podem ser captadas em parte nas "Teses sobre Feuerbach". As teses VIII e XI estabelecem, respectivamente, que "Toda vida social é essencialmente prática. Todos os mistérios que conduzem a teoria ao misticismo encontram sua solução racional na prática humana e na compreensão desta prática" e que "os filósofos apenas interpretaram o mundo de diferentes maneiras; o que importa é transformá-lo"84.

Daquela primeira tese mencionada se extrai uma guinada teórica da maior relevância no pensamento ocidental, porque, no fundo, explicita que a teoria é inelutavelmente dependente da prática. Não é que a questão da relação entre teoria e prática seja nova, como já observado no capítulo 1, sobre o modo pelo qual Hegel concebia o enraizamento do pensamento no real. Mas a formulação marxiana tem o condão de aplacar elucubrações idealistas no sentido de que questões teóricas se resolvem no âmbito da razão, estando inelutavelmente, porém, enraizadas no real.

Da segunda tese acima mencionada ("os filósofos apenas interpretaram o mundo de diferentes maneiras; o que importa é transformá-lo") se extrai a potência do pensamento e da crítica - o pensamento crítico se desenvolve pela consciência de que o existente se transforma inclusive sob o impulso da ação humana pensada.

Marx não desenvolveu uma teoria abrangente e sistemática sobre o direito ou sobre os direitos humanos. Entretanto, o seu legado teórico, assim como as

84 K. MARX, F. ENGELS, A ldeologia Alemã, p. 535. 
diversas referências pontuais sobre o direito em suas obras, têm grande relevância para a teoria e para a filosofia do direito ${ }^{85}$. A principal questão que move este capítulo é o distanciamento entre a teoria dos direitos humanos e o método marxista, de modo que as questões aqui enunciadas têm o objetivo precípuo de encurtar tal distanciamento.

Deve-se observar que Marx também não procedeu, em sua extensa obra, a um exame imanente do direito ou dos direitos humanos, nos moldes da análise que fez no campo da economia política. Seus escritos sobre os "direitos do homem", em geral, desenvolvem questões de ordem política e apenas marginalmente de ordem lógica. István Mészáros, em seu texto "Marxismo e Direitos Humanos" realiza uma exposição compreensiva sobre os direitos humanos, partindo de indicações de ordem lógica dadas pelo próprio Marx em sua obra econômica e filosófica. É o estudo aprofundado desta leitura que se pretende nos capítulos que seguem.

Observa-se que "o alvo da crítica de Marx à filosofia já era o distanciamento entre a esta e o mundo real"86, a contradição constatada entre pensamento e realidade. Esta crítica de Marx à filosofia permeia toda a sua trajetória intelectual e sua disposição crítica diante dos diversos campos de conhecimento com que tomou contato: história, direito, economia, etc. Assim, o pensamento de Marx está marcado pelo diagnóstico das contradições existentes entre os discursos e as práticas sociais em diversos campos ${ }^{87}$, contradições estas que, no contexto da sociedade capitalista, aparecem como contradições

85 Ressaltando esta importância, A. L. MASCARO. Filosofia do Direito, 2011, p. 446, afirma que a filosofia do direito do marxismo é o momento mais alto da reflexão jurídica contemporânea", tratando-se da "compreensão mais aprofundada do fenômeno jurídico e do entendimento dos seus nexos estruturais a partir das relações sociais atuais".

86 I. MÉSZÁROS. Marx Filósofo. In HOBSBAWN, Eric. J. História do Marxismo, Vol. 1, 1983, p. 160.

87 Assim, a crítica de Marx ao direito também explicitou o distanciamento entre a teoria e o mundo real: após examinar Cartas de Direitos do século XVIII, constatando que a liberdade religiosa era prevista como direito humano, verificou que a liberdade e a igualdade universais não passavam de expressões, refletidas no Estado, da liberdade e da igualdade (contratuais) requeridas para o desenvolvimento da economia capitalista, a qual, ao mesmo tempo, requer a desigualdade substantiva, a desigualdade real que permite a mercantilização da força de trabalho. Neste sentido, segundo a leitura de István Mészáros sobre Marx, para este os "direitos do homem" são problemáticos "em função do contexto em que se originam, enquanto postulados ideais abstratos e irrealizáveis, contrapostos à realidade desconcertante da sociedade de indivíduos egoístas" (I. MÉSZÁROS, István. Marxismo e Direitos Humanos, 2008). 
estruturais decorrentes dos imperativos da reprodução sociometabólica do capital.

A ideia de que "não é a crítica, mas a revolução a força motriz da história e também da religião, da filosofia e de toda forma de teoria" ${ }^{88}$ revela duas coisas: em primeiro lugar, a importância e até mesmo a primazia da prática no desenvolvimento da teoria. Tal primazia não poderia ser entendida como determinação mecânica ou matemática da teoria pela prática, vez que a complexidade desta relação envolve uma determinação dialética, havendo entre teoria e prática mútuo condicionamento e interação. Em segundo lugar, a referência a "toda forma de teoria" explicita como Marx e Engels entendiam haver certa homologia entre as diversas formas de conhecimento, homologia esta que chegou à radical formulação de que a "lei" de que mudanças puramente quantitativas se transformando em mudanças qualitativas valeriam tanto na história como nas ciências naturais.

Para o que importa neste momento, deve-se ressaltar que a metodologia crítica, ao apontar contradições no campo da superestrutura jurídica, não tem a crítica como fim em si mesmo, mas tem por finalidade contribuir para as práticas sociais emancipatórias. Isto é particularmente relevante no campo dos direitos humanos, os quais aparecem com especificidades nos campos do direito, da política e da moral. Quanto a estas especificidades, deve-se de apontar como as perspectivas teóricas distintas veem coisas diferentes no fenômeno real dos direitos humanos; a teoria do direito vê normas de direitos humanos, que são válidas ou não, podem ou não ser eficazes e são objeto de aplicação e interpretação; a teoria política pode enxergar os direitos humanos como instrumentos de dominação e consolidação de certo modo de vida; a teoria moral pode ver os direitos humanos como deveres morais, que devem ser observados para uma pacífica convivência social. A perspectiva crítica pode aplicar-se a cada qual destes campos separadamente, mas em todos eles tal perspectiva tem por finalidade trazer à tona a dimensão da história e do seu desenvolvimento.

No sentido metódico referido, o alvo de uma crítica aos direitos humanos deve ser o distanciamento característico entre o direito e certos problemas sociais existentes, ou seja, a expressão parcial e seletiva destes problemas na técnica jurídica e, por consequência, na teoria do direito. Não há um total alijamento do 
direito em relação ao "mundo real", mas uma expressão seletiva de fatos no direito - neste sentido, a criação de um "mundo real ideal" próprio ao direito, um mundo parcial, que não abarca todas, nem as mais importantes determinações, um mundo seletivamente desenhado na teoria. Seletividade que se explicita em sua negatividade quando se constata que problemas sociais candentes, que podem ser identificados em demandas de sujeitos sociais e políticos (organizados ou não), não têm expressão no modus de validade ou de efetividade jurídica, tratando-se de matéria estranha ao direito.

Quando se trata de direitos humanos, cuja força expansiva do conceito parece abranger todos os aspectos da vida humana, na medida em que cada aspecto contribui para uma vida digna e satisfatória, os limites da tecnologia jurídica e da sua seletividade se explicitam. A ideia de "ineficácia" das garantias de direitos humanos surge como válvula de escape teórica para estes limites, enquanto a distinção entre direitos humanos e direitos fundamentais aparece como o modo explícito (embora não reconhecido) de assumir que a dogmática jurídica não está interessada em eficácia de direitos, mas apenas em sua validade e em sua sistematicidade interna (que, na verdade, esconde interessadamente a origem dos direitos numa desigual disputa política legislativa).

Este distanciamento entre a teoria dos direitos humanos e os anseios que os direitos humanos parecem veicular é uma contradição latente no seio das lutas sociais hodiernas. A discussão sobre uma metodologia crítica dos direitos humanos busca oferecer um instrumental teórico adequado a estas lutas sociais, na medida em que, para tais lutas, a tecnologia jurídica por si só é insuficiente e, no limite, contraproducente.

A crítica de Marx aos "direitos do homem" explicitou justamente este distanciamento entre a teoria dos direitos humanos e os anseios que tais direitos parecem veicular: após examinar a Declaração dos Direitos do Homem e do Cidadão, de 1871, a Constituição da Pensilvânia e a Constituição de NewHampshire, constatando que a liberdade religiosa era prevista como direito humano, Marx verificou que, estruturalmente, tais direitos são os direitos do "membro da sociedade burguesa", do "homem como mônada isolada"

A liberdade assegurada e este "homem egoísta", "separado da 
comunidade", que "não se baseia na vinculação do homem com os demais homens" ${ }^{90}$, está apoiada na separação entre homem e cidadão, a qual reflete a contradição entre desigualdade privada e igualdade pública, bem como entre desigualdade substantiva e igualdade formal. Assim, a liberdade e a igualdade universais não passam de expressões refletidas no Estado da liberdade e da igualdade (contratuais) requeridas para o desenvolvimento da economia capitalista que, ao mesmo tempo, requer a desigualdade substantiva.

As lutas sociais hodiernas desenvolvem-se, ainda, em meio à contradição entre desigualdade privada e igualdade pública ${ }^{91}$. E em seu desenvolvimento os sujeitos do trabalho não rejeitam as ideias de liberdade e igualdade, mas as tomam ${ }^{92}$ em um sentido próprio, que pode ser mesmo distinto do sentido atribuído pelos poderes instituídos ao quanto expresso nas Constituições e Declarações de direitos que se multiplicam desde o final do século XVIII, mas com mais intensidade desde o fim da Segunda Guerra Mundial. Nestas declarações, tais ideias são expressas como direitos e, na prática social, são submetidas ao formalismo jurídico institucional, o qual é determinado pela base na qual este direito existe; nas lutas sociais, que eclodem assim que a exploração capitalista se estabelece, e não depois ${ }^{93}$, aquilo que está positivado como direito persistirá

90 Idem.

91 Isto é, uma desigualdade real existente na anatomia da sociedade civil e uma desigualdade abstrata reconhecida em instâncias institucionais. Mesmo quando estas instâncias reconhecem diferenças e desigualdades, tal reconhecimento é meramente formal, como toda a igualdade institucional.

92 Mais ou menos como, segundo LEBRUN, Gérard, La patience du concept, edição brasileira $A$ paciência do conceito: ensaio sobre o discurso hegeliano, São Paulo: UNESP, 2006, apud SAFATLE, Vladimir, 12 Lições Sobre Ciência da Lógica de Hegel - Aula 5, disponível em www.cienciadalogica.com/aula5, consultado em 27 de setembro de 2011: "Tal é a única surpresa que a passagem ao especulativo reserva: esta lenta alteração que parece metamorfosear as palavras que usávamos inicialmente, sem que, no entanto, devamos renunciar a elas ou inventar outras".

93 Para aqueles aferrados a uma "história das ideias", pode parecer que as lutas sociais eclodem apenas no século XIX quando a teoria da luta social atinge seu auge com as formulações de Marx e Engels acerca do socialismo. Ocorre que as notícias da "luta de classe", longe de terem sido "inventadas" por Marx e Engels, vêm desde os tempos em que se aprofunda e expande a exploração do capital pelo trabalho, sendo oportuno registrar que M. BEER, História do Socialismo e das Lutas Sociais, 2006, expõe sob a ótica materialista o modo como se deram as lutas sociais na História, passando pela análise de movimentos como os estoicistas, o comunismo primitivo, o utopismo moderno e o socialismo contemporâneo. Em todos eles as contradições sociais afloram em razão da divisão da sociedade em classes. No que tange, à contemporaneidade, a p. 368 ss., BEER lembra que Charles Hall, em obra de 1805, "procura formular e explicar cientificamente o antagonismo 
como ideal ampliado, como bandeira de luta, como tematização de um horizonte que está para além do futuro imediato proporcionado pelas condições materiais existentes no sistema sociometabólico do capital.

Segundo a leitura de István Mészáros sobre Marx, para este os "direitos do homem" são problemáticos "em função do contexto em que se originam, enquanto postulados ideais abstratos e irrealizáveis, contrapostos à realidade desconcertante da sociedade de indivíduos egoístas"94. Assim, as teorias que embasam os direitos humanos foram duramente criticadas por Marx justamente em razão do elemento ilusório que envolviam, "em sua abstração das condições materiais de uma transformação social radical" 95 .

Destarte, os direitos humanos não são incompatíveis com o marxismo, como levam a crer leituras estreitas ou enviesadas do marxismo ou dos direitos humanos. A principal objeção de Marx, neste sentido, se refere à "contradição fundamental entre os 'direitos do homem' e a realidade da sociedade capitalista,

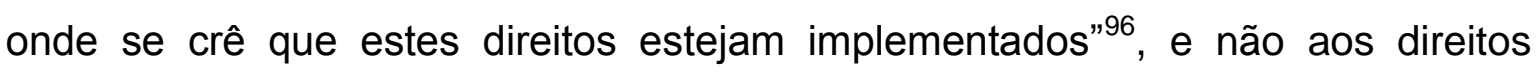
humanos em si. A perspectiva de análise de István Mészáros abre um caminho para uma interpretação crítica dos direitos humanos, numa leitura adequada da crítica de Marx, que desvende o modo como tais direitos podem ser embasados de modo a afastar-se do formalismo jurídico e do juspositivismo e conduzir a teoria a preocupações mais profundas com a efetividade, na busca pela superação daquela contradição fundamental "entre os 'direitos do homem' e a realidade da sociedade capitalista, onde se crê que estes direitos estejam implementados".

Anos depois de escrever "Sobre a Questão Judaica", Marx retoma a crítica aos direitos do homem na "Crítica ao Programa de Gotha". Neste texto fica clara a crítica ao unilateralismo metódico que remete conceitos de liberdade, igualdade e equidade a uma esfera abstratamente jurídica, sem considerar as relações econômicas e sociais efetivamente existentes.

irredutível entre o capital e o trabalho... e critica as instituições sociais com bastante violência. Entretanto, limita-se a apresentar proposições de reformas moderadas: nacionalização do solo, volta ao artesanato, simplicidade de costumes, supressão do luxo etc".

94 I. MÉSZÁROS, István. Marxismo e Direitos Humanos, 2008.

95 Idem, p. 158.

96 Idem. 
"Que é 'repartição eqüitativa'? Os burgueses não afirmam que a repartição atual é 'eqüitativa'? E, realmente, na base do atual modo de produção, não é a única repartição 'eqüitativa' possível? As relações econômicas são reguladas por ideias jurídicas ou não serão, ao contrário, as relações jurídicas que nascem das relações econômicas? (...) O direito nunca pode ser mais elevado que o estado [situação] econômico da sociedade e o grau de civilização que lhe corresponde"97.

Esta crítica coloca o problema da relação existente entre superestrutura jurídica e base econômica ${ }^{98}$ e, a rigor, o problema do modo unilateral de tratar os "direitos do homem", do modo de concebê-los como algo a ser codificado no céu do direito, distanciando-se das disputas que ocorrem no chão das relações sociais efetivas.

A crítica aos "direitos do homem" não deveria excluir a noção de um "papel vital de um sistema de direitos orientado para o socialismo" ${ }^{99}$. De fato, tal sistema de direitos "orientado para o socialismo" seria um aparato superestrutural adequado ao funcionamento de uma economia qualitativamente diferente, baseada no princípio "a cada um de acordo com sua necessidade", conforme indicado por Marx na "Crítica ao Programa de Gotha".

Ocorre que tal mudança qualitativa não pode ser antecipada, mas apenas buscada no contexto das lutas sociais específicas, das lutas sociais existentes, tendo os princípios enunciados por Marx o sido justamente no seio do estudo das condições das lutas sociais de seu tempo. A finalidade da mudança qualitativa não implica a necessidade de abandonar pautas de luta relevantes para as mudanças quantitativas. Isto afasta a simplificação que vê nos direitos humanos meros instrumentos de cooptação das classes trabalhadoras e demais movimentos sociais pelo Estado burguês, desprezando que aquilo que se expressa como demandas por direitos são antes pautas resultantes das necessidades humanas que, nas lutas sociais eventualmente aparecem como demandas por direitos. Esta visão dialética dos direitos humanos enquanto discurso de lutas sociais e ao mesmo tempo como instrumentos de submissão aos limites do direito não permite que se permaneça nos limites daquela simplificação.

97 K. MARX. Crítica ao Programa de Gotha, 2004, p. 105. e 109.

98 A este respeito, vide J. D. L. TRINDADE. Os Direitos Humanos na Perspectiva de Marx e Engels: emancipação política e emancipação humana, 2011, p. 227 e seguintes.

99 I. MÉSZÁROS. Marxismo e Direitos Humanos, 2008, p. 157. 
Os direitos humanos aparecem como instrumentos de cooptação dos sujeitos do trabalho ao serem positivados e instrumentalizados pelo Estado capitalista, o sendo na medida em que o sistema reprodutivo sociometabólico do capital possa suportar ${ }^{100}$. Esta denúncia é um pressuposto para a teoria crítica, estando assente nas mais diversas formulações e conclusões das teorias marxistas sobre os direitos humanos. Mas ela, embora imprescindível, não esgota a crítica. Tal crítica soma para a luta social na medida em que pode evitar que a finalidade última dela sejam conquistas parciais dentro da superestrutura jurídica e política, o que acarretaria apenas a manutenção do sistema social existente e das ilusões sobre um "capitalismo humanizado".

Também é necessária uma perspectiva "positiva" da crítica marxista, o que envolve buscar o que nos direitos humanos postos nas pautas de movimentos sociais está somando para a superação da superestrutura jurídica alienada. Esta dimensão dos direitos humanos, não raro desprezada pela crítica, é capaz de fundamentar as atividades táticas dos movimentos sociais. Estas atividades não são menores ou secundárias na luta pela transformação social - ao contrário, devem ser vistas já como o percurso mesmo da transformação social, como a transformação social em movimento. A dimensão "negativa" da crítica, por si só, não poderia oferecer esta fundamentação - se restasse apenas a dimensão "negativa", ao contrário, o que ficaria seria apenas a crítica soberba às lutas mais imediatas; ainda, se restasse apenas a dimensão "negativa" da metodologia crítica, os movimentos sociais, nas lutas imediatas, seriam levados, como por vezes o são, a recorrer a esquemas não dialéticos e idealistas na concepção teórica de suas lutas imediatas. Trata-se de uma lacuna ocasionada por uma deficiência do discurso crítico, muitas vezes incapaz de fornecer instrumental

100 De fato, como expressivamente afirma I. MÉSZÁROS, István. Marxismo e Direitos Humanos, 2008 , p. 165 , "a condição elementar para o bom funcionamento do metabolismo social, numa sociedade em que a estrutura econômica não esteja livre de contradições, é o papel ativo da superestrutura legal e política, tornado possível por sua autonomia relativa da base material que, por sua vez, implica necessariamente a autonomia relativa das ideias e formas de consciência social em relação à própria superestrutura legal e política... É nesse quadro de complexas interações dialéticas que a ideia de direitos humanos se torna compreensível e verdadeiramente significativa, pois, quaisquer que sejam as determinações materiais de uma sociedade de classe, suas contradições são toleráveis apenas até o ponto onde começam a ameaçar o próprio metabolismo social fundamental". 
teórico adequado a tais lutas.

Assim, na medida em que os direitos humanos são enunciados como pautas de luta de movimentos sociais, a própria conceituação jurídica de tais direitos fica já carente de pleno sentido. Tais direitos aparecem, aí, prenhes de sentido político, mesmo que tenham por finalidade alterar a superestrutura jurídica. Por isso, não se deve abandonar o recurso aos direitos humanos na luta social mais avançada, não obstante os fatos de que os conceitos se confundem nas expressões de sujeitos históricos distintos e antagônicos e de que a classe hegemônica impõe certa concepção e uma interpretação formalista de tais direitos humanos.

Os sujeitos do trabalho, não obstante as ideias dominantes e os riscos da falsa consciência, estão potencialmente cientes de seus limites, dos limites de suas lutas, e dos limites dos direitos humanos - as lutas que empreendem se dão justamente forçando estes limites para além, de modo que não se poderia conceber o desconhecimento de tais limites. Os limites de tais direitos são os limites mesmo do metabolismo social subjacente, que impõe restrições à produção e à distribuição de acordo com os interesses da própria reprodução capitalista. Em suma, pode-se dizer que os direitos humanos enquanto bandeiras de luta são a finalidade da luta social, em contraste aos direitos humanos como garantias formais do direito ou como os pressupostos ideais para a reprodução social do capital. A superação desta forma de reprodução social, em direção a uma em que a finalidade seja o pleno desenvolvimento das individualidades, exige que as bandeiras de lutas dos movimentos sociais sejam levadas em conta pela crítica, pois aí é que aparecem as indicações rumo àquela superação. 


\section{CAPÍTULO 4: A CONTRADIÇÃO ENTRE A ENUNCIAÇÃO DE GARANTIAS DE DIREITOS E A INEFICÁCIA DESTES.}

A contradição entre a enunciação de garantias de direitos humanos e a ineficácia de tais direitos é a questão central da crítica marxista aos direitos humanos. Como já mencionado, a principal objeção de K. Marx aos "direitos do homem" se refere à "contradição fundamental" entre tais direitos e "a realidade da sociedade capitalista, onde se crê que estes direitos estejam implementados" 101 . Realmente, do ponto de vista jurídico, os "direitos do homem" seriam aqueles direitos assegurados pelo ordenamento, aptos a serem legitimamente arguidos em Juízo ou defendidos nas esferas político-jurídicas. Por meio dos procedimentos pertinentes ao direito, não por outros meios, é que se poderiam efetivar tais direitos. Assim, a instrumentalidade mesma do direito prega e sustenta a separação entre a esfera jurídica, onde são assegurados universalmente todos os direitos humanos, e a mundo real, onde tais direitos são constantemente negados e violados.

No ensaio Marxismo e Direitos Humanos, István Mészáros discutiu a relação entre direito e marxismo, dando especial atenção aos "direitos do homem" e ao modo como Marx os concebeu ${ }^{102}$. Segundo Mészáros, a superestrutura política e jurídica é localizada por K. Marx "na rede das inter-relações dialéticas entre a base material de uma determinada sociedade e suas várias instituições e formas de consciência"103. Como já ressaltado no Capítulo 1 deste trabalho, no Prefácio de 1859 da "Contribuição à Crítica da Economia Política", Marx esclarece:

"Nas minhas pesquisas cheguei à conclusão de que as
relações jurídicas, assim como as formas de Estado - não
podem ser compreendidas por si mesmas, nem pela dita
evolução geral do espírito humano, inserindo-se, pelo contrário
nas condições materiais de existência de que Hegel, à
semelhança dos ingleses e franceses do século XVIII,
compreende o conjunto pela designação de 'sociedade civil';

101 Idem.

102 O título original do ensaio é "Marxism and Rights", mas a tradução para o português, refletindo o conteúdo do próprio ensaio, foi feita para "Marxismo e Direitos Humanos".

103 I. MÉSZÁROS. Marxismo e Direitos Humanos, 2008, p. 157. 
por seu lado, a anatomia da sociedade civil deve ser procurada na economia política

(...)

A conclusão geral a que cheguei e que, uma vez admitida, serviu de fio condutor dos meus estudos, pode formular-se resumidamente assim: na produção social da sua existência, os homens estabelecem relações determinadas, necessárias, independentes da sua vontade, relações de produção que correspondem a um determinado grau de desenvolvimento das forças produtivas materiais. O conjunto destas relações de produção constitui a estrutura econômica da sociedade, a base concreta sobre a qual se eleva uma superestrutura jurídica e política e a qual correspondem determinadas formas de consciência social”"104.

Ao discutir este trecho, Mészáros explicita a inter-relação tripla entre base real, superestrutura jurídica e política e formas de consciência social. Ressalta, ademais, a predominância da superestrutura jurídica e política no contexto atual sobre outras formas de consciência social.

A crítica de Marx aos "direitos do homem" se apoia principalmente na constatação, de natureza histórica, de que se tratavam de meros direitos particulares de uma classe, a classe burguesa ${ }^{105}$, assim, de direitos assegurados na esfera estatal para permitir a reprodução do sistema sociometabólico do capital. Tais direitos não estão, entretanto, efetivados universalmente enquanto tais, mas apenas se efetivam sob os limites deste sistema. Em razão disso, é possível afirmar que "o objeto da crítica de Marx não consiste nos direitos humanos enquanto tais, mas no uso dos supostos 'direitos do homem' como racionalizações pré-fabricadas das estruturas predominantes de desigualdade e dominação" ${ }^{\text {106. }}$.

Esta leitura de Mészáros se apoia não apenas em obras do "jovem Marx", envolvendo também obras como o já referido Prefácio à "Contribuição à Crítica da Economia Política", "Crítica do Programa de Gotha", "Grundrisse" e "O Capital". Daí que, se o ponto de partida do autor está na observação de que "os direitos do

104 K. MARX. Contribuição para a crítica da Economia Política, 1973, p. 28.

105 Crítica desenvolvida primeiro em K. MARX. Sobre a Questão Judaica, 2010, onde se faz uma análise curta e profunda dos droit de l'homme, num dos momentos da central crítica à particularidade: "os chamados direitos humanos, os droits de l'homme, ao contrário dos droits du citoyen, nada mais são do que direitos do membro da sociedade burguesa, isto é, do homem egoísta, do homem separado do homem e da comunidade".

106 I. MÉSZÁROS. Marxismo e Direitos Humanos, 2008, p. 161. 
homem se tratavam de meros direitos particulares de uma classe", afirmação esta feita por Marx na obra de juventude "Sobre a Questão Judaica" (obra não explicitamente tratada por Mészáros), se trata justamente de uma afirmação que é interpretada e fundamentada no contexto de toda a obra de Marx, não apenas das obras da juventude - mesmo porque a distinção radical entre um jovem Marx e um Marx maduro, para Mészáros, é despropositada ${ }^{107}$.

Bem entendido este ponto, trata-se de apontar que os direitos humanos enquanto garantias formais racionalizadas são incapazes de tocar nos problemas sociais reais, em razão de sua origem estar justamente no seio das estruturas predominantes de desigualdade e dominação. Os direitos humanos se constituem historicamente como formalização, como positivação de conquistas da classe burguesa emergente, no interesse da modificação das estruturas existentes na sociedade feudal e da conformação de novas estruturas de desigualdade e dominação. O seu desenvolvimento, com absorção de demandas sociais, se dá apenas nos limites tolerados pela reprodução social do capital.

A ausência de mecanismos protetivos de diversos direitos humanos no ordenamento jurídico (em termos doutrinários jurídicos, a não observância do ubi jus ibi remedium), exigindo que as necessidades correspondentes sejam buscadas na luta política ou mediante um acesso ao Judiciário bastante dificultado, apenas confirmam que a efetividade destes direitos não é uma pauta inerente ao direito. Isto não significa que estas questões não possam ser objeto de preocupação de juristas, e, realmente, normalmente o são, sem que se

107 I. MÉSZÁROS. A Teoria da Alienação em Marx, 2006, pp. 197 e seguintes. De fato, a ideia de que haveria um corte epistemológico entre o jovem Marx e o Marx maduro não faz sentido para István Mészáros. Para este, Marx não afastou de seu campo de reflexão temas como o homem, o gênero humano, o sujeito, a alienação, etc. Haveria em Marx, isto sim, um amadurecimento intelectual, por meio do qual tais temas seriam cada vez mais fundados numa vigorosa teoria crítica, numa teoria e filosofia marxistas. O objeto de estudo de Marx sempre teria sido a ordem burguesa, sendo abordadas diversas temáticas relacionadas a tal objeto, sempre numa perspectiva crítica - crítica à religião, crítica à filosofia, crítica à política, crítica à economia política. István Mészáros tenta demonstrar a) que o jovem Marx não era um idealista, que ele não tratava das questões filosóficas como questões atemporais, ao contrário, ele sempre as situou como questões inerentes à ordem burguesa; b) que a noção de alienação não desapareceu no Marx maduro, sendo errôneas as interpretações dadas aos usos de Marx deste termo n'A Ideologia Alemã e no Manifesto Comunista ( $A$ Teoria da Alienação em Marx, 2006, p. 198), onde supostamente teria abandonado tal conceito; como explica István Mészáros, Marx "não abandonou a palavra e muito menos o conceito [de alienação]", apontando o filósofo húngaro várias passagens em que Marx valeu-se do conceito de alienação em suas obras de maturidade. 
consiga dar qualquer resposta apropriada com o instrumental técnico do direito ou teórico da filosofia do direito alheia à crítica. Daí a importância da perspectiva crítica que busque, justamente, oferecer respostas mais adequadas a tais problemas, problemas estes candentes nas lutas sociais cotidianas ${ }^{108}$, já que "seria completa insensatez negar o papel ativo e vitalmente importante do quadro legal no desenvolvimento e estabilização, bem como na reprodução contínua da sociedade, em circunstâncias mutáveis e diante de pressões tanto internas como externas" 109 .

Os "direitos do homem", enquanto racionalizações pré-fabricadas, são direitos positivados e são cristalizações, no ordenamento, de lutas sociais passadas (na fase ascendente do capitalismo, de lutas sociais burguesas, na fase descendente, em geral, de lutas sociais trabalhistas e de diversos movimentos reivindicatórios de direitos). O sucesso destas lutas sociais leva à garantia formal de direitos humanos, com o que tais direitos passam a submeter-se às limitações dos mecanismos jurídicos para efetivar-se. A eficácia de tais direitos dependerá, então, de uma série de fatores, dentre eles, não raro, algum tipo de ativismo, mobilização ou vigilância permanente.

A melhoria relativa ${ }^{110}$ das condições de vida da classe trabalhadora desde

108 Vide, por exemplo, M. O. PINASSI. Da Miséria Ideológica à Crise do Capital, 2009, p. 84, onde a autora narra a criminalização da luta pela terra no Rio Grande do Sul e deixa claro como setores dominantes capturam o instrumental jurídico contra os movimentos sociais, mas nem por isso deixam de atuar politicamente para evitar que demandas progressistas sejam viabilizadas na seara jurídica: "As justificativas [para o não assentamento de 2 mil famílias] mais uma vez recaíram sobre os ruralistas de São Gabriel e os 'meios de persuasão' que costumam utilizar para exigir que sua região seja considerada 'área livre de assentamento'. Para isso lançam mão de toda sorte de ameaças contra técnicos do Incra e contra proprietários em dívida com a União - caso da Fazenda Southal - para que não vendam suas terras para o órgão da federação e sim para as transnacionais do agronegócio, campeãs na compra de terra no estado... Mais importante, porém, é que a situação relatada nos coloca diante do fato de que a ofensiva reacionária dos poderes executivo e judiciário do RS visa, sobretudo, à criminalização da luta pela terra reencaminhando a reforma agrária - essa nossa velha divisa histórica - para a esfera da clandestinidade".

109 I. MÉSZÁROS. Marxismo e Direitos Humanos, 2008, p. 162.

110 Esta "melhoria relativa" não implica que tenha sido equivocada ou precipitada a afirmação de Marx de que "o trabalhador se torna tanto mais pobre quanto mais riqueza produz", in $\mathrm{K}$. MARX. Manuscritos Econômico-filosóficos, 2004, p. 80. O desvendar da alienação do trabalho na sociedade capitalista, na qual o trabalhador "baixa à condição de mercadoria" e na qual a miséria deste se põe em relação inversa à potência e à grandeza de sua produção, continua plenamente aplicável ao contexto atual. Ocorre que uma cisão no seio da própria classe trabalhadora implica na formação de uma "elite trabalhista" que se usa do reformismo para manter ganhos relativos e condições materiais de vida favoráveis para esta parcela 
os tempos de Marx criou alguns desafios teóricos ${ }^{111}$ sobre as questões da conscientização, da mobilização e organização das lutas sociais e também sobre o papel do quadro legal nestas lutas. A emergência dos direitos humanos sociais, outrossim, alterara significativamente a realidade examinada por Marx e Engels, e posteriormente, no que tange mais especificamente ao direito, por Pasukanis ${ }^{112}$. Os direitos humanos, em todo este período e após, aprofundam seu caráter contraditório, levando os mais diversos movimentos sociais recorrerem a tal discurso, de modo que tais direitos passam a aparecer ao mesmo tempo como

elitizada da classe que vive da venda de sua força de trabalho. O mais interessante a ser constatado neste contexto é que a constatação de que quanto mais o trabalhador produz, menos ele tem em termos relativos, continua plenamente atual, já que mesmo com a formação de uma "elite trabalhista", as "posses" acessadas por esta "elite" em razão de salários relativamente elevados não chegam a interferir minimamente na apropriação privada do excedente pelos detentores dos meios de produção. Por isso a distância entre ricos e pobres, desde os tempos de Marx, não apenas continua abissal, como aumenta constantemente, apesar da formação de uma camada intermediária chamada "classe média".

111 Boa parte destes desafios teóricos está diretamente relacionada à questão dos direitos humanos. Como expõe, por exemplo, J. N. GREEN. Além do Carnaval - A Homossexualidade Masculina no Brasil do século XX, 2000, p. 433, ressaltando os desafios da organização nas lutas contra as opressões, na época da ditadura militar brasileira, "os estudantes se queixavam de que a esquerda brasileira era homofóbica. Estudantes de esquerda apoiavam Fidel Castro e a Revolução Cubana argumentavam que combater temas específicos, como sexismo, racismo e homofobia, iria dividir o crescente movimento contra o regime militar. Eles sustentavam que as pessoas deveriam se unir em uma luta geral contra a ditadura".

112 E. B. PASUKANIS. A teoria geral do direito e o marxismo, 1989. Eugeny Pasukanis desenvolveu a crítica imanente ao direito de maneira muito precisa em sua mais importante obra, "A Teoria Geral do Direito e o Marxismo", de 1924. Sua pretensão declarada era aplicar o método materialista dialético ao direito, tal qual Marx aplicara à economia política. Assim, em tal obra, Pasukanis expõe o modo pelo qual a finalidade precípua da forma jurídica é "mediar e estabelecer vínculos entre dois agentes econômicos que se põem em contato no mercado". O principal mérito de Pasukanis está em buscar apontar como o direito é uma forma historicamente específica, essencialmente capitalista e, como tal, intimamente ligado às relações de troca de mercadorias entre sujeitos privados. Segundo Pasukanis, o ato de contratar é central no direito burguês e a relação jurídica cumpre um papel fundamental no capitalismo. É "a partir das necessidades concretas postas pelo Modo de Produção Capitalista que o Direito burguês irá construir uma de suas categorias fundamentais, que é a igualdade", sendo que a "igualdade jurídica é a contrapartida lógica e necessária da desigualdade econômica". A descrição de Pasukanis sobre o direito burguês esclarece algumas das determinações deste: "O vínculo social entre os homens no processo de produção, vínculo reificado nos produtos do trabalho e sob a forma de uma legalidade elementar, exige, para a sua realização, uma relação particular entre os homens enquanto indivíduos que dispõem de produtos, enquanto sujeitos cuja 'vontade habita nas próprias coisas' (K. Marx, O Capital, cap. II, p. 95)... ao mesmo tempo em que o produto do trabalho reveste as propriedades da mercadoria e torna-se portador de valor, o homem torna-se sujeito de direito e portador de direitos" (p. 84-85). 
dominação e como resistência ${ }^{113}$.

Ao aparecerem como garantias no ordenamento jurídico, aderem à lógica do direito, refreando as demandas sociais à medida necessária ou não prejudicial à reprodução social metabólica do capital, enquanto, ao mesmo tempo, atuam como instrumentos de legitimação política ${ }^{114}$. Por outro lado, ao serem empunhados como bandeiras de luta pelos movimentos sociais, seja quando busquem a efetividade (forçando interpretações mais favoráveis ou implementação de políticas públicas) do que está já positivado, seja quando busquem interesses que, tendentes a mitigar a exploração e a dominação, não são acolhidos pela legalidade, atuam como instrumentos de deslegitimação jurídica e política. Este caráter contraditório leva a uma tensão que, se devidamente explorada, pode explicitar o potencial emancipador e apontar alternativas à lógica jurídica formalista.

A contradição fundamental entre os 'direitos do homem' e a realidade desigual da sociedade capitalista é nutrida pela teoria jurídica liberal, a qual "trata a esfera dos direitos como independente e auto-regulada" ${ }^{115}$. O elemento ilusório das teorias liberais dos "direitos do homem" derivou de um exercício de abstração seletiva das condições materiais da transformação social radical que levaram do feudalismo ao capitalismo. Isto levou a defesa de tais direitos a submeter-se ao

113 Mesmo porque, enquanto "a transformação social radical defendida por Marx torna-se possível apenas se o peso da esfera legal for devidamente reconhecido, diante do desafio representado pelas próprias estruturas legais específicas no interior do processo global", o problema [conforme K. MARX e F. ENGELS, Draft plan for a work on the modern state (1845) em Collected Works (Nova York, International Publishers, 1975), v. IV, apud I. MÉSZÁROS. Marxismo e Direitos Humanos, 2008, p. 162] "é que 'todas as entidades existem de forma duplicada, como entidades civis e entidades do Estado'. Por isso, nada se resolve apenas pela proclamação de direitos, nem mesmo pela mais solene proclamação dos direitos do homem. A esfera legal se torna eficaz na medida em que se introduz profundamente no corpo da 'sociedade civil'... Quando Marx se refere à 'luta pela superação do Estado e da sociedade civil', nessa interligação necessária dos dois, ele reconhece não apenas a 'forma duplicada' em que as entidades civis e do Estado existem e coexistem em interpenetração recíproca, mas também, simultaneamente, o poder imenso que as estruturas legais exercem até que a transformação radical da sociedade civil seja realmente efetivada".

114 Neste último sentido, como explica ALMEIDA, Silvio Luiz de, Reflexões sobre 'Legalidade e llegalidade' em História e Consciência de Classe, in http://www.unicamp.br/cemarx/anais_ v_coloquio_arquivos/arquivos/comunicacoes/gt1/ses sao6/Silvio_Almeida.pdf, afirma que "Na visão de Lukács, a ideologia jurídica, como já foi visto, tem a função de tornar a aceitação da estrutura econômica da sociedade como algo pacífico, sem que o fundamento violento da luta de classes apareça" (G. LUKÁCS. História e Consciência de Classe, 2003, p. 465 e seguintes).

115 I. MÉSZÁROS. Marxismo e Direitos Humanos, 2008, p. 158. 
formalismo, ao individualismo e ao patrimonialismo legitimadores da desigualdade substantiva emergente, mantendo o universalismo de tais direitos na esfera ideal.

O poder dominante das formas estruturais legais tem importância central na dinâmica da dominação e da desigualdade, o que se reflete decisivamente na elaboração e positivação dos direitos humanos. Isto ilustra como o quadro legal, inclusive os direitos humanos, com seu papel ativo"116, assegura uma esfera independente e autorregulada, a qual é a expressão superestrutural de uma estrutura social de privilégios e garantias fundadas no sociometabolismo do capital.

Daí a censura de Marx à igualdade jurídica, tal como esta se mostrava nas legislações estatais, no interesse do sociometabolismo do capital, e a constatação de que a insistência liberal sobre os "direitos do homem" não se trata de mais que um postulado legalista-formal e de uma defesa particularista dos próprios interesses de classe. A contradição igualdade jurídica/desigualdade substantiva real está incrustada na anatomia da sociedade civil (isto é, na esfera da economia política, no mundo da materialidade), expressando-se nas desiguais condições objetivas de vida. Tais contradições existentes no capitalismo são toleráveis neste sistema na medida em que não ameacem o metabolismo social fundamental. Assim, quando tal ameaça ocorre, "a auto-legitimação dessa sociedade é minada radicalmente e seu caráter de classe é rapidamente desmascarado, através de seu fracasso em se manter como sistema correspondente às necessidades dos direitos humanos elementares"117.

116 Idem, p. 162.

117 Num trecho significativo de I. MÉSZÁROS. Marxismo e Direitos Humanos, 2008, p. 165, citado em parte no texto, lê-se que "a condição elementar para o bom funcionamento do metabolismo social, numa sociedade em que a estrutura econômica não esteja livre de contradições, é o papel ativo da superestrutura legal e política, tornado possível por sua autonomia relativa da base material - que, por sua vez, implica necessariamente a autonomia relativa das ideias e formas de consciência social em relação à própria superestrutura legal e política... É nesse quadro de complexas interações dialéticas que a ideia de direitos humanos se torna compreensível e verdadeiramente significativa, pois, quaisquer que sejam as determinações materiais de uma sociedade de classe, suas contradições são toleráveis apenas até o ponto onde começam a ameaçar o próprio metabolismo social fundamental. Quando isso acontece, a auto-legitimação dessa sociedade é minada radicalmente e seu caráter de classe é rapidamente desmascarado, através de seu fracasso em se manter como sistema correspondente às necessidades dos direitos humanos elementares. Dessa forma, paradoxalmente, as condições de sua legitimação anterior - 0 apelo aos direitos humanos bem-sucedido ideologicamente - se volta contra ela, uma vez que, à época de uma crise devastadora do próprio metabolismo social, não é mais capaz de se proclamar como 
O sistema jurídico se estrutura de tal forma que os "direitos do homem" reconhecidos são apenas aqueles aptos a serem defendidos em Juízo ou nas esferas político-jurídicas (o que se entende atualmente por direitos fundamentais). Não é necessário enfatizar mais os sérios problemas, já mencionados, relativos ao acesso às instâncias decisórias existentes. Dos entraves a este acesso decorre a ineficácia dos direitos humanos assegurados positivamente, e eles não são entraves fortuitos, mas têm sua explicação na própria anatomia da sociedade civil. Assim, há uma contradição fundamental entre a enunciação de garantias de direitos e a ineficácia destes.

As teorias do direito e dos direitos humanos liberais funcionam como legitimadoras de interesses ideológicos, consagrando o formalismo e 0 individualismo metodológicos, pautas políticas das revoluções burguesas. Esta consagração do formalismo envolve o movimento típico de transferir os problemas e as contradições da vida real para a esfera legislativa da razão, transcendendo a conflitualidade real ${ }^{118}$. Já a consagração do individualismo efetiva uma "inversão radical da relação estrutural objetiva entre diferentes tipos de conflitos e antagonismos"119, partindo de uma natureza humana fictícia (de indivíduos naturalmente egoístas) e chegando a uma "universalização" do próprio indivíduo individual $^{120}$.

A abstração do direito é vista pela teoria crítica marxista não como um traço a ser corrigido na teoria, mas como uma "contradição insolúvel da própria estrutura social"121. Não se pode esperar, então, uma solução a nível estritamente teórico para a contradição apontada. O que importa é investigar possíveis resoluções para contradições reais. Estas contradições, no contexto capitalista, se explicitam no contraste entre a defesa abstrata dos "direitos do homem" e a defesa dos "direitos da alienabilidade universal e posse exclusiva". Tal contraste invalida "de modo efetivo os mesmos 'direitos do homem' que pretendem estabelecer"122.

representante da realização mais adequada às aspirações humanas".

118 I. MÉSZÁROS. Estrutura Social e formas de consciência, 2009, p. 28.

119 Idem, p. 52.

120 Idem, pp. 137 e ss.

121 I. MÉSZÁROS. Marxismo e Direitos Humanos, 2008, p. 159.

122 Idem, p. 159. 
Segundo István Mészáros, a solução de Marx para a contradição referida estaria na extinção necessária do direito à posse exclusiva, já que esta significou, com a superação do feudalismo e o advento do capitalismo, a exclusão da maioria da posse efetiva. Tal solução expressa o projeto de superação revolucionária do capitalismo, único meio capaz de extinguir as contradições em questão sem que tais contradições levem à destruição das condições de reprodução da existência humana.

Ante o exposto, o passo metodológico na crítica marxista dos direitos humanos que deve ficar claro é o seguinte: deve-se realizar uma análise contextual (histórica) acerca de quais são os direitos garantidos, qual a condição de vida dos supostos destinatários destes direitos e quais são as reivindicações que estes destinatários veiculam. Trata-se de identificar, assim, quais dos "direitos do homem" não são efetivados e aparecem como garantia meramente positivada, contraditória à sua inexistência na vida real. Ao apontar a exclusão generalizada da grande maioria da população do gozo do direito à posse exclusiva, apesar do seu deferimento universal, Marx já denunciava o modo como esta contradição se dava no contexto do capitalismo.

Ao desenvolver este primeiro passo metodológico na análise dos direitos humanos, István Mészáros explicita que uma "alternativa socialista para a forma de intercâmbio capitalista não pode ignorar a questão dos direitos humanos" ${ }^{123}$. A ideia de Marx de que o proletariado está apto para a tarefa da emancipação humana universal deve ser avaliada levando-se em conta o histórico dos movimentos socialistas desde que tal diagnóstico foi realizado e a atuação dos movimentos sociais contra-hegemônicos existentes hoje. Tal avaliação parte da pressuposição de que "a derrota da classe exploradora é um falso triunfo caso não acarrete a emancipação dos indivíduos como indivíduos" 124. E tal pressuposição diz respeito diretamente aos direitos humanos, em seu desenvolvimento contraditório no contexto capitalista.

Ao afirmar que uma "alternativa socialista para a forma de intercâmbio 
capitalista não pode ignorar a questão dos direitos humanos”125, István Mészáros afasta-se de perspectivas objetivistas e economicistas que não dão a devida importância à problematização das dimensões superestruturais, dentre as quais os direitos humanos. Mas se afasta também do idealismo, na medida em que sua perspectiva está amparada na noção de que a superação da superestrutura jurídica e política é uma questão que diz respeito à transformação qualitativa antagônica da ordem socioeconômica do capital ${ }^{126}$. E tal fica claro na exposição de Mészáros sobre a relação entre direitos humanos e marxismo quando afirma que "ou a interpretação de Marx como reducionista econômico é insustentável, ou suas referências constantes do papel ativo das formas ideológicas são totalmente desprovidas de significado" e, embora não desenvolvendo o ponto, que "Basta dizer que a condição necessária, para uma intervenção ativa das idéias nos processos materiais, é sua mediação através da ação de indivíduos e instituições, que ocupam necessária posição intermediária entre os dois, na medida em que são simultaneamente materiais e ideais"127.

Pode-se concluir, então, que a contradição entre a garantia e a ineficácia de direitos humanos não implica, necessariamente, que a pauta dos direitos deva ser rejeitada em quaisquer circunstâncias como uma pauta idealista, reformista, incapaz de atingir os problemas reais. Na verdade, trata-se de uma pauta inerente às lutas numa sociedade em que prevalece o modo de produção capitalista e a organização jurídico-política baseada na igualdade e na liberdade - apenas no sistema de produção capitalista se desenvolvem a liberdade e a igualdade requeridas para as equalizações formais necessárias, e apenas neste sistema é que os direitos humanos fazem sentido enquanto tais, enquanto direitos formais reconhecidos e enquanto bandeiras de luta que entram em contradição com as formalizações impostas desde as bases objetivas. A constatação de tal contradição é o primeiro passo de uma análise crítica dos direitos humanos, e seu desprezo implica, na verdade, em não compreender o verdadeiro papel que devem ter os direitos humanos nas lutas emancipatórias.

125 Idem, p. 165.

126 Isto fica claro na discussão específica sobre a transformação radical da superestrutura jurídica e política, I. MÉSZÁROS. Estrutura Social e Formas de Consciência II, 2011, p. 172.

127 I. MÉSZÁROS. Marxismo e Direitos Humanos, 2008, p. 163. 


\section{CAPÍTULO 5: A CRÍTICA ÀS CONCEPÇÕES JURÍDICAS DOMINANTES E A AVALIAÇÃO DO SISTEMA DE DIREITO.}

As formas ideológicas funcionais ao sistema sociometabólico do capital aparecem na dogmática jurídica liberal e podem ser examinadas por meio de uma crítica às concepções jurídicas dominantes (as quais decorrem das ideias das classes dominantes). Este exame tem como pressuposto a linha de demarcação entre a "superestrutura ontologicamente intranscendível" e a "superestrutura jurídica e política", que possibilita vislumbrar uma alternativa à legalidade separada e à normatividade abstrata ${ }^{128}$.

O papel ativo da superestrutura jurídica leva à inadiável necessidade de sua compreensão, pelos sujeitos do trabalho. Ao mesmo tempo, as alternativas só poderiam ser gestadas no seio da confrontação desta superestrutura jurídica alienada. Esta confrontação exige o exame dos direitos humanos positivados num dado contexto histórico, com a avaliação tanto do contexto social quanto do sistema de direito existentes, além da interconexão entre eles. Confirmando a ideia de que é na prática da luta dos sujeitos do trabalho que as respostas às dúvidas aqui suscitadas serão encaminhadas, István Mészáros afirma, verbis, que:

"Uma das principais exigências a esse respeito é que todos os valores defendidos - não apenas a igualdade, por exemplo devem emergir da prática social efetiva em progresso e ser definidos em termos substantivos. Uma das características principais das conceituações da ordem reprodutiva do capital, mesmo em sua fase ascendente de desenvolvimento, era que - devido às divisões e contradições de classe que não poderiam ser erradicadas do sistema - a dimensão substantiva era empurrada para o fundo e a definição formal dos valores positivos era oferecida em seu lugar. Basta lembrar-nos do tratamento de Kant da questão da igualdade nesse âmbito. Evidentemente, o valor da liberdade (ou autonomia) necessita tanto de uma determinação substantiva de sua louvável natureza na ordem reprodutiva socialista quanto a igualdade. $\mathrm{O}$ mesmo se aplica à solidariedade, cooperação e responsabilidade, para citar apenas alguns poucos dos mais importantes valores na ordem hegemônica alternativa do

128 I. MÉSZÁROS. Estrutura Social e Formas de Consciência II, 2011, p. 103. 
trabalho. Todos esses conceitos, acompanhados da igualdade e da liberdade, poderiam ser reduzidos a seus esqueletos formalizados, como de fato foram caracteristicamente transfigurados, na medida em que sequer foram advogados, mesmo no passado progressista do capitalismo. Eles adquirem legitimidade na estrutura societal socialista somente se forem adotados na qualidade de valores e princípios orientadores em seu genuíno - e mais relevante - sentido substantivo" ${ }^{129}$.

Nas condições encontradas pelos sujeitos do trabalho, o modus de expressão jurídica não raro parece ser o meio mais adequado para assegurar a satisfação das necessidade por que lutam. Ao menos quando se nota que aqueles poucos que desfrutam de condições para terem direitos plenamente efetivados têm a seu alcance os instrumentos do direito. Cria-se a impressão de que o direito poderia representar a redenção da luta social, como se a consagração ritualística de direitos ou a disponibilização de mecanismos jurídicos de efetividade de garantias conquistadas pudessem, por si, assegurar a superação das necessidades reais.

Num contexto de crescente juridicização (isto é, de expansão e dominância das superestruturas jurídicas e políticas) da vida social, juridicização esta aprofundada na fase descendente do capitalismo ${ }^{130}$, os movimentos sociais passam cada vez mais a submeter a expressão de suas necessidades ao modus de validade jurídica para, na expectativa de assegurar por este meio a posição de poder que o direito proporciona, buscar eficácia na satisfação das necessidades prementes. Porém, na verdade, a posição de poder que o direito proporciona é que, na verdade, proporciona o poder ao direito, isto é, o direito é expressão do poder exercido pela classe capitalista a partir da dominação dos meios de produção e da apropriação do excedente produtivo.

Neste sentido, a juridicização crescente das relações sociais não pode levar a crer que o direito seja a solução das referidas necessidades prementes. Tal crença apenas tende a aprofundar a própria juridicização. A busca pela satisfação das referidas necessidades não é uma questão estritamente jurídica, embora à luta na seara do direito deva ser dado o devido peso pelos movimentos sociais. Assim é que, assumindo que o momento da luta jurídica é inevitável no

129 I. MÉSZÁROS. A Crise Estrutural do Capital, 2009, p. 127-8.

130 I. MÉSZÁROS. Estrutura Social e Formas de Consciência II, 2011, p. 149 e seguintes. Como já visto, por exemplo, no capítulo 1, a fls. 18 e 19. 
contexto capitalista, impõe-se uma análise crítica das concepções jurídicas dominantes e uma avaliação dos sistemas de direitos sob os quais se luta.

Mas tal deve ser feito tendo em vista a observação de István Mészáros de que "A proposição marxiana de que 'os homens devem mudar de cima a baixo as condições de sua existência industrial e política, e consequentemente toda a sua maneira de ser' permanece mais do que nunca válida como direção estrategicamente necessária do projeto socialista"131. Tal assertiva se dá sob o pressuposto de que "a radical transcendência do Estado é um lado da moeda... complementada pelo outro lado, a saber, pelo projeto de mediações concretas pelas quais a estratégia final pode ser progressivamente traduzida em realidade" ${ }^{132}$.

De fato, "o sistema do capital, por sua própria natureza, é um modo de controle global/universalista, que não pode ser historicamente superado exceto

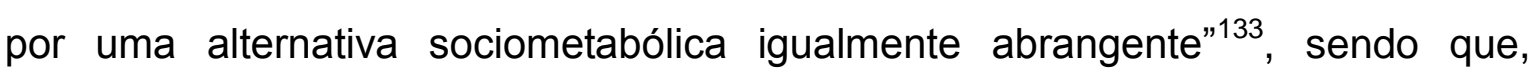
porque materialmente interligados, "nem o capital, nem o trabalho, nem sequer o Estado podem ser simplesmente abolidos, mesmo pela mais radical intervenção jurídica"134. Daí a importância do desenvolvimento da crítica em todas as searas superestruturais, inclusive na dos direitos humanos, mas também a importância de se ter presente que o fenecimento do Estado e o fenecimento do capital não podem acontecer senão conjuntamente ${ }^{135}$.

131 I. MÉSZÁROS. Para Além do Capital, 2002, p. 598.

132 Idem, p. 597. Outrossim, István Mészáros afirma que "Já que para o futuro previsível os horizontes da política como tal não podem ser transcendidos, isso significa simultaneamente 'negar' o Estado e atuar no seu interior... Assim, a tarefa se define como um duplo desafio visando: (1) instituir órgãos não-estatais de controle e crescente auto-administração... e conforme permitem as condições (2) produzir um deslocamento consciente nos próprios órgãos estatais ... de modo a tornar viável a realização das perspectivas históricas últimas do projeto socialista" E arremata afirmando que "certamente, todos esses processos estão articulados à maturação de algumas condições objetivas. Enfrentar toda a problemática do Estado envolve uma multiplicidade de determinações externas e internas em sua íntima interconectividade...".

133 Idem, p. 599.

134 Idem, p. 600. Daí István Mészáros concluir, em dura crítica ao modelo soviético, que "não é, portanto, de modo algum acidental que a experiência histórica tenha produzido abundantes exemplos de fortalecimento do Estado pós-revolucionário, sem dar sequer o menor passo na direção de seu 'fenecimento'".

135 A grande questão que surge é como manter a consciência do fenecimento das formas mercantil, jurídica e estatal e ao mesmo tempo valer-se destas formas nas lutas sociais sem legitimar a sua existência. Um indicativo de resposta a tal questão pode ser buscado em István Mészáros, para quem "a alternativa radical da nova ordem histórica deve ser articulada 
Como se viu, a crítica aos "direitos do homem" feita por Marx decorre da especificidade histórica deste. Empreendendo uma "crítica radical às concepções jurídicas dominantes", atento aos "problemas da teoria jurídica e da função do Estado na administração do direito" ${ }^{136}$. Daí a necessidade de compreender o modo como atuam as concepções jurídicas dominantes, inclusive o modo como convivem com a inefetividade enquanto algo inerente a sua própria existência. Este passo metodológico é importante na medida em que é o único modo capaz de explicitar como, no interior da teoria dos direitos humanos, os limites a tais direitos se colocam, e o fazem a partir do formalismo. Este é um ponto menos desenvolvido por István Mészáros na obra de referência deste trabalho ("Marxismo e Direitos Humanos"), embora haja referência a ele. Não obstante, se trata de um passo importante na metodologia de análise dos direitos humanos, sendo que o desenvolvimento deste passo metodológico seria o que mais se aproximaria de uma crítica imanente do direito.

Trata-se de uma análise que se volta, assim, à lógica interna da teoria do direito e da teoria dos direitos humanos. Tal análise pressupõe a constatação das contradições existentes entre estas teorias, em seu formalismo abstrato, e a realidade excludente. Esta análise, neste contexto, não pode deixar de ser um análise crítica, no sentido de submeter a própria teoria a seus próprios limites, de trazer à luz tanto aquilo que a teoria explicita quanto aquilo que ela exclui ou deixa implícito - de revelar, assim, a seletividade e a parcialidade envolvidas na técnica jurídica.

O esforço desenvolvido em diversos momentos por István Mészáros para problematizar a noção de igualdade e resolvê-la sempre enquanto igualdade substantiva está no âmbito desta crítica às concepções dominantes. De fato, em

de modo consistente também no campo dos valores. Uma das principais exigências a esse respeito é que todos os valores defendidos - não apenas a igualdade, por exemplo - devem emergir da prática social efetiva em progresso e ser definidos em termos substantivos" (I. MÉSZÁROS. A Crise Estrutural do Capital, 2009, p. 127). Esta abordagem é uma poderosa arma crítica para os sujeitos do trabalho e seus movimentos sociais na aproximação à questão dos direitos humanos. De fato, no âmbito tático, a abordagem substantiva ganha especial relevância, no sentido de que o aprofundamento das pautas substantivas dos sujeitos do trabalho força as contradições das próprias formas típicas do capitalismo.

136 I. MÉSZÁROS. Marxismo e Direitos Humanos, 2008, p. 157. 
"O desafio do desenvolvimento sustentável e a cultura da igualdade substantiva", István Mészáros afirma que só pode haver desenvolvimento significativo no futuro se o desenvolvimento for sustentável e que "a condição inseparável da busca por desenvolvimento sustentável é a realização progressiva da igualdade substantiva"137.

Por longo tempo se esperou que o desenvolvimento e a modernização pudessem, progressivamente, resolver os problemas sociais, mas tal se afigura cada vez mais como uma falácia. As condições objetivas atuais envolvem o desperdício cada vez mais descontrolado, a escassez de energia, a perpetuação e o agravamento de desigualdades apesar de todo "progresso", o que levou à necessidade de "qualificar todo desenvolvimento futuro como desenvolvimento sustentável"138. Tal desenvolvimento só faz sentido em sua plenitude com a realização dos direitos humanos, da igualdade substantiva, o que envolve a crítica daqueles direitos tais como são requisitados e assegurados no contexto capitalista. Neste contexto, ainda é dominante a cultura da desigualdade substantiva, apesar de "esforços quase sempre indiferentes para impugnar o impacto prejudicial da desigualdade social por meio da instituição de mecanismos de igualdade estritamente formal na esfera da política" ${ }^{139}$.

A liberdade é reduzida à liberdade de contratar por meio da igualdade entre as partes e a igualdade é reduzida à "'liberdade' de aspirar à concessão de nada além da 'igualdade de oportunidade' formalmente proclamada", de modo que os significados de liberdade e igualdade "são transformados em determinações abstratas que se sustentam de maneira circular" ${ }^{140}$, tornando a ideia de fraternidade redundante. Efetivamente, os pilares dos direitos humanos liberais tais como se desenvolvem no contexto do capitalismo são os direitos formais à igualdade e à liberdade, inexistindo "direito à fraternidade" neste contexto.

Esta crítica às noções de liberdade e igualdade é um exemplo de crítica a concepções jurídicas dominantes $^{141}$, as quais se dão no contexto de uma disputa

137 I. MÉSZÁROS. O Desafio e o Fardo do Tempo Histórico, 2007, p. 185.

138 Idem, p. 190.

139 Idem, p. 186.

140 Idem, p. 188.

141 Outro exemplo desta crítica pode ser colhido em K. MARX. O capital: crítica da economia política. O processo global da produção capitalista. Livro Terceiro. Volume V, 1988, p. 255, onde o "reino da liberdade" é concebido não como a disponibilidade para contratar livremente, 
conceitual, de um conflito dos sujeitos do trabalho com as concepções dominantes, que não é mais que reflexo de uma disputa muito real que se dá no seio da estrutura social, entre a manutenção das estruturas existentes, que exigem liberdade e igualdade postas em fórmulas formais abstratas, e a alteração radical de tais estruturas para que liberdade e igualdade sejam postas de modo substantivo.

Assim, com a defesa da igualdade substantiva feita por István Mészáros, o que se está a defender são os direitos humanos na perspectiva dos sujeitos do trabalho, isto é, numa perspectiva que liga o desenvolvimento econômico ao desenvolvimento social e individual, de modo que sustentabilidade só pode significar estar "realmente no controle dos processos sociais, econômicos e culturais vitais"142 - o que, em termos filosóficos, expressa a superação da alienação. Neste sentido é que se pode afirmar que "a maneira significativamente economizadora de regular nosso processo de reprodução sociometabólica, com base no controle interno/autodirigido, como oposto ao controle externo/de cima para baixo, que prevalece hoje, é radicalmente incompatível com a desigualdade e a conflitualidade/adversidade estruturais" ${ }^{143}$.

O tom desta abordagem é dado por István Mészáros nos seguintes termos:

"O controle do domínio jurídico é obviamente o primeiro passo necessário na trilha para uma transformação social duradoura qualitativa. Mas não deve permitir que se converta, como

mas como algo que "só começa, de fato, onde cessa o trabalho determinado pela necessidade e pela adequação a finalidades externas; portanto, pela própria natureza da questão, isso transcende a esfera da produção material propriamente dita... Nesse terreno, a liberdade só pode consistir em que o homem social, os produtores associados, regulem racionalmente esse seu metabolismo com a Natureza, trazendo-o para seu controle comunitário, em vez de serem dominados por ele como se fora por uma força cega; que o façam como o mínimo emprego de forças e sob as condições mais dignas e adequadas à sua natureza humana. Mas este sempre continua a ser um reino da necessidade. Além dele é que começa o desenvolvimento das forças humanas, considerado como um fim em si mesmo, o verdadeiro reino da liberdade, mas que só pode florescer sobre aquele reino da necessidade como sua base. A redução da jornada de trabalho é a condição fundamental".

142 I. MÉSZÁROS. O Desafio e o Fardo do Tempo Histórico, 2007, p. 190.

143 Idem, p. 191. Como visto na nota anterior, isto conflui com a citação anterior de K. MARX. O capital: crítica da economia política. O processo global da produção capitalista. Livro Terceiro. Volume V, 1988, p. 255, que afirma que "Nesse terreno, a liberdade só pode consistir em que o homem social, os produtores associados, regulem racionalmente esse seu metabolismo com a Natureza, trazendo-o para seu controle comunitário, em vez de serem dominados por ele como se fora por uma força cega". 
convém às personificações herdadas ou novas do capital, em uma variante nova de ilusão jurídica adotada de maneira esperançosa" ${ }^{144}$.

Ou seja, não se deve esquecer que o direito é expressão do poder exercido pela classe capitalista a partir da dominação dos meios de produção e da apropriação do excedente produtivo. Este controle do domínio jurídico não diz respeito à mera tomada do poder e à instauração por decreto de uma sociedade revolucionária pela classe trabalhadora. $\mathrm{O}$ malogro das experiências de tipo soviético demonstram suficientemente as limitações desta via. Por outro lado, as experiências de tipo social democrata também malograram enormemente ao confiar às estruturas estatais estabelecidas o manejo da distribuição de recursos, na esperança de que esta via poderia humanizar e, ao depois, revolucionar o sistema sociometabólico do capital.

Ocorre que o desenvolvimento de uma crítica imanente ao direito em István Mészáros é primário, passando apenas superficialmente por ela ${ }^{145}$. Sua crítica mais vigorosa remete, ao contrário, a questão dos direitos humanos a searas

144 I. MÉSZÁROS. Estrutura Social e Formas de Consciência, 2009, p. 299.

145 Ao contrário de István Mészáros, em E. Pasukanis se encontra uma vigorosa crítica imanente ao direito. Assevera o jurista soviético como ponto de partida de sua exposição que "Toda relação jurídica é uma relação entre sujeitos. O sujeito é o átomo da teoria jurídica, seu elemento mais simples, indecomponível" (E. B. PASUKANIS. A teoria geral do direito e o marxismo, 1989, p. 81). Para a universalização e consolidação da troca capitalista, todos os indivíduos precisaram ser reconhecidos, no nível formal, como indistintamente livres e iguais. Deste necessário reconhecimento, e não de uma natureza humana inata, surgem os direitos de liberdade e igualdade. Esta relação íntima entre direito e capitalismo é apontada de modo irretocável por Pasukanis, que identifica com precisão a relação entre direito e relação de mercadorias. Mas os limites da teoria pasukaniana devem ficar claros, mesmo porque a intenção de Pasukanis é elaborar uma crítica da "teoria geral do direito", restringindo-se, em sua obra, aos elementos conceituais deste campo teórico. Assim, no âmbito desta crítica à teoria geral do direito, E. Pasukanis descreve a íntima relação existente entre a forma jurídica e a forma mercantil, ou, segundo observado por P. I. Stucka e corroborado pelo próprio Pasukanis, busca "aproximar a forma do direito da forma da mercadoria" (p. 2). De fato, o próprio Marx já esclarecera que o surgimento e o funcionamento do direito estão estreitamente vinculados "às determinações do processo do valor de troca" (M. B. NAVES. Marxismo e Direito - um estudo sobre Pachukanis, 2000, p. 103), uma vez que a liberdade (vide K. MARX, O Capital, pp. 199, 293, 345, 414-415), a igualdade e a forma sujeito (universal) emergem apenas no capitalismo (M. B. NAVES. Marxismo e Direito - um estudo sobre Pachukanis, 2000, p. 103). Pasukanis, aliás, fala destas três determinações ao se referir ao homem enquanto enquanto sujeito econômico egoísta; enquanto sujeito moral, pessoa igual a outras; e enquanto sujeito de direito, enquanto proprietário; determinações estas que são o conjunto de "condições necessárias à realização da relação do valor" (E. B. PASUKANIS. A teoria geral do direito e o marxismo, 1989, p. 128). 
políticas. E, nesta seara política, não deixa dúvida de que os direitos humanos, como "todas as funções de controle do sociometabolismo - que sob todas as formas de dominação do capital devem estar investidas na estrutura de comando material e política de um poder de tomada de decisão alienado" devem ser progressivamente apropriados e positivamente exercidos pelos produtores associados" $^{\text {"146 }}$. Porém, quanto ao modo como tal se dará, István Mészáros não adentra mais profundamente na concretude das concepções jurídicas dominantes, restando tal desafio às teorias jurídicas críticas.

Como já afirmado, o repúdio à "ilusão jurídica" implica a busca de condições sob as quais as desigualdades substantivas não sejam invisibilizadas por instrumentos teóricos formalistas e sob as quais a vontade individual não seja anulada pelo "poder reificador das condições materiais e institucionais dominantes" ${ }^{\text {147 }}$. Por isso o repúdio à ilusão jurídica significaria o repúdio à reificação e ao formalismo, não um repúdio ao conteúdo potencialmente emancipatório que a luta social enuncia como direitos humanos e que a lógica jurídica busca submeter. Assim, deve-se ressaltar como passo metodológico a análise dos conceitos utilizados pela teoria jurídica e o modo como a sua conceituação no seio dos sistemas de direito restringem aquelas necessidade que movimentos sociais, por vezes, buscam efetivar por meio destes mesmos "direitos". Em suma, necessário o desenvolvimento de uma crítica específica, de natureza lógica, às concepções jurídicas dominantes que obstam a efetividade dos direitos humanos em dado contexto.

Algumas críticas de István Mészáros, como a acima exposta sobre a questão da igualdade substantiva, são úteis enquanto ponto de partida para uma crítica às concepções jurídicas dominantes e para uma avaliação do sistema de direito. A crítica às concepções jurídicas dominantes envolve confrontar as conceituações postas pelo discurso "oficial" dos direitos humanos com conceituações críticas, que levem ao limite a questão da satisfação das necessidades humanas, ainda que pondo em cheque o modo de apropriação do excedente socialmente produzido. As contradições inerentes ao discurso jurídico dominante se explicitam ao apontar as contradições entre o discurso de garantias

146 I. MÉSZÁROS. Para Além do Capital, 2005, p. 602.

147 I. MÉSZÁROS. Marxismo e Direitos Humanos, 2008, p. 164. 
formais e a realidade de sua inefetividade, mas a crítica imanente de as concepções jurídicas dominantes revela com toda a clareza os limites estabelecidos pela superestrutura jurídica. A referida avaliação do sistema de direito, assim, nada mais é do que a totalidade da crítica às concepções jurídicas dominantes, necessária para o encaminhamento de estratégias de transformação de tal sistema que retirem obstáculos à garantia e efetivação de direitos humanos tais como empunhados pelos sujeitos do trabalho. 


\title{
CAPÍTULO 6: A BUSCA DAS CONDIÇÕES DE NÃO- ANULABILIDADE DA VONTADE INDIVIDUAL E O LADO ATIVO DOS DIREITOS HUMANOS.
}

No Prefácio de 1859 da "Contribuição à Crítica da Economia Política", Marx afirmava que

\begin{abstract}
"Assim como não se julga um indivíduo pela ideia que ele faz de si próprio, não se poderá julgar uma tal época de transformação pela sua consciência de si; é preciso, pelo contrário, explicar esta consciência pelas contradições da vida material, pelo conflito que existe entre as forças produtivas sociais e as relações de produção" ${ }^{148}$.
\end{abstract}

A consciência deve ser explicada a partir das contradições da vida material - esta uma conclusão metodológica básica da filosofia marxista. Por isso, a confiança dos movimentos sociais depositada nos direitos humanos deve ser explicada também a partir das contradições da vida material destes movimentos.

De fato, a necessidade da desigualdade substantiva para a reprodução sociometabólica do capital é o que explica que sob a ótica estatal e jurídica os direitos humanos sejam postos como direitos formais e abstratos, enquanto que a substantivação é apenas pressuposta e, na prática, é negada pelos próprios mecanismos estatais que supostamente garantiriam a efetividade dos direitos positivados.

Por outro lado, a confrontação dos sujeitos do trabalho com as concepções jurídicas dominantes permite que os direitos humanos apareçam nos discursos e práticas de movimentos reivindicatórios como luta pela substantivação - é dizer, aparecem como um discurso em contradição com aquilo que está posto e pressuposto pelo discurso jurídico dominante. Esta luta pela substantivação pressupõe a perspectiva do revolucionamento estrutural do sistema sociometabólico do capital, embora tais movimentos sociais nem sempre tenham esta reformulação explicitamente em suas pautas mais imediatas de luta. Não o tem como pautas postas, mas na perspectiva do sujeito social do trabalho, este revolucionamento está pressuposto, aparecendo como o limite das próprias lutas 
sociais no contexto do capitalismo.

Os direitos humanos aparecem, assim, como direitos contraditórios, e também assim na consciência dos movimentos sociais, apresentando um lado positivo (que leva ao potencial revolucionamento), e um lado negativo (que leva ao controle social). A autorrealização humana aparece como horizonte nesta consciência que confronta as concepções dominantes e se opõe às perspectivas ameaçadoras da autodestruição.

Segundo Mészáros, Marx - "tanto o 'jovem' quanto o 'velho' - insiste no 'desenvolvimento livre das individualidades', antecipando um quadro de interação social em que os homens vivem 'sob condições mais favoráveis e dignas da sua natureza humana' (O Capital, v. III, p. 800 na edição Nova York, International Publishers, 1894, v. III)" e conclui que "Igualmente, seu modo de apontar para a alternativa dramática de 'socialismo ou barbárie' apela ao interesse maior da autorealização humana, como oposta às perspectivas ameaçadoras da autodestruição: essa negação essencial, categórica e final de todos os direitos humanos"149.

A emancipação humana, o desenvolvimento livre das individualidades, bem como o estudo das condições para a autorrealização humana são elementos que atravessam axiologicamente toda a obra de Marx e levam a esmaecer, numa visão total de tal obra, as diferenças entre o "jovem Marx" e o "Marx maduro"150. É

149 I. MÉSZÁROS. Marxismo e Direitos Humanos, 2008, p. 165. O trecho citado por István Mészáros é o já referido K. MARX. O capital: crítica da economia política. O processo global da produção capitalista. Livro Terceiro. Volume V, 1988, p. 255.

150 Para alguns pensadores, com destaque para Louis Althusser (Pour Marx, 2005, p. 225 ss.), há um corte epistemológico entre o jovem Marx e o Marx maduro. Nesta perspectiva, Marx teria rompido com o "humanismo", afastando de seu campo de reflexão temas como o homem, o gênero humano, o sujeito, a alienação, etc, desenvolvendo a ciência da história a partir de conceitos científicos como modo de produção, forças de produção, infraestrutura/superestrutura, etc. Porém, para István Mészáros, não há corte epistemológico algum na obra de Marx, mas apenas amadurecimento intelectual. A obra da juventude de Marx seria um pressuposto da obra da maturidade - com efeito, esta sequer poderia ser adequadamente compreendida sem aquela. O objeto de estudo de Marx sempre foi a ordem burguesa, sendo abordadas diversas temáticas relacionadas a tal objeto, sempre numa perspectiva crítica - crítica à religião, crítica à filosofia, crítica à política, crítica à economia política. O que István Mészáros tenta demonstrar é a) que o jovem Marx não era um idealista, que ele não tratava das questões filosóficas como questões atemporais, ao contrário, ele sempre as situou como questões inerentes à ordem burguesa; b) que a noção de alienação não desapareceu no Marx maduro, sendo errôneas as interpretações dadas aos usos de Marx deste termo n'A Ideologia Alemã e no Manifesto Comunista ( $A$ Teoria da Alienação em Marx, 2006, p. 198, onde István Mészáros problematiza se tais passagens foram 
o que se constata em passagens como a seguinte, no Grundrisse:

"Na economia burguesa - e na era da produção que lhe corresponde -, esse desenvolvimento completo do conteúdo humano aparece como um esvaziamento completo, essa objetificação universal, como alienação total, e 0 desmoronamento de todos os objetivos limitados e parciais, como um sacrifício do fim-em-si humano a um fim inteiramente externo" ${ }^{151}$.

Estas preocupações de Marx se relacionam com o modo como este lidava com a questão da "natureza humana". Para Marx, é na "vida", ou melhor, na "natureza humana" contextual, que será encontrado o fundamento para o próprio pensar e também para o conflito entre realidade e pensamento. Realmente, há uma pretensão filosófica em Marx que foi resolvida por este em sua concepção peculiar de "natureza humana" ou, nos termos utilizados nos Manuscritos de Paris, "essência humana".

A essência humana em Marx não é uma essência metafísica; a "essência" ou "natureza" humana, na verdade, sequer é algo que se encontra no indivíduo profundo, mas está fora do ser humano, sendo algo "que se define naturalmente

corretamente interpretadas: afirma que há realmente duas frases irônicas em " $A$ Ideologia Alemã" com as palavras "estranhamento" e "auto-estranhamento", - "Esta 'alienação' (para usarmos um termo compreensível aos filósofos) só pode ser superada, evidentemente, sob dois pressupostos práticos" e "O processo inteiro foi, então, apreendido como processo de auto-alienação do 'Homem"'. Para István Mészáros, a contraposição entre a posição de Marx nos Manuscritos (que ainda lutaria com o conceito de alienação) e na Ideologia Alemã (onde haveria uma "opinião final" de Marx sobre tal conceito) seria enganosa - Marx deixara claro "mais de uma vez, em seus Manuscritos Econômicos-filosóficos, que toma como ponto de partida a linguagem da economia política a fim de resgatar suas contribuições, que permaneciam ocultas aos próprios economistas políticos, bem como para criticá-los em seus próprios termos"; uma leitura cuidadosa dos textos, segundo István Mészáros, deixa claro que não há rejeição do auto-estranhamento, mas crítica à "abstração filosófica que substitui o indivíduo real (histórica e socialmente concreto) pela imagem idealista do homem abstrato, e com isso mistifica o estranhamento efetivo do homem real (o indivíduo social), ao representálo como estranhamento na consciência... Essa objeção, bem conhecida por nós desde seus escritos anteriores, não faz a noção de 'auto-estranhamento do homem real' nem um pouco obsoleta". As mesmas observações são desenvolvidas por István Mészáros quanto ao uso do conceito de alienação no Manifesto Comunista - a crítica de Marx "não está dirigida ao conceito de alienação, mas ao seu uso idealista, porque esse uso o 'emascula totalmente', priva-o de seu conteúdo social concreto e do poder de crítica prática". Enfim, István Mészáros afirma que Marx "não abandonou a palavra e muito menos o conceito [de alienação]", apontando o filósofo húngaro várias passagens em que Marx valeu-se do conceito de alienação em suas obras de maturidade).

151 Apud I. MÉSZÁROS, O Século XXI. Socialismo ou Barbárie, 2003, p. 18. 
como a relação necessária do ser objetivo com seus objetos, ou seja, é uma relação objetiva específica" ${ }^{152}$.

Portanto, a "natureza humana não é algo fixado pela natureza, mas, pelo contrário, uma 'natureza' que é feita pelo homem em seus atos de 'autotranscendência' como ser natural" ${ }^{153}$, sendo que "a 'essência' ou 'natureza' do ser humano não pode ser encontrada no interior do sujeito, mas fora dele, em suas relações objetivadas"154.

Por isso não se poderia admitir a Ideia como fundamento do pensamento, como fundamento da Lógica e da dialética do espírito, já que esta dialética tem íntima ligação, ou uma homologia radical, com a dialética da existência material, da natureza ou essência humana. O conhecimento decorre das próprias condições de existência do ser humano, e esta afirmação deve ser levada mais a sério diante da "dúvida metódica" e do problema do fundamento substantivo. Por isso a própria categoria de direitos humanos não pode ser examinada sem remetê-la a seu fundamento substantivo ou, especificamente, sem remetê-la ao uso de tal categoria nas lutas sociais hodiernas.

Enquanto o direito natural dos direitos humanos parte do "postulado de que a realização plena da natureza humana perene demandaria o atendimento ou a garantia de certas necessidades, expressas como direitos" ${ }^{155}$, na teoria crítica o problema da emancipação humana se coloca em termos radicalmente distintos, numa dupla perspectiva epistemológica e prática. Na perspectiva epistemológica, trata-se de analisar a visão da própria teoria sobre si mesma como parte do mundo, como imersa neste, incapaz de puxar-se para fora da areia movediça ${ }^{156}$, de modo a relação entre as bases reais (objetivas) e a teoria filosófica e do direito é vista como uma relação dialética, como elementos que se autodeterminam mutuamente. O problema prático está em saber em que medida a perspectiva marxista pode ir mais longe nas propostas de resolução dos problemas relativos à "ineficácia real dos direitos" ou aos "limites objetivos à emancipação". Estes dois problemas ou perspectivas têm íntima relação e são objeto de preocupação da

152 I. MÉSZÁROS. A Teoria da Alienação em Marx, 2006, p. 155.

153 Idem, p. 156.

154 Idem, p. 162.

155 J. D. de L. TRINDADE. Os direitos humanos na perspectiva de Marx e Engels, 2010, p. 216. 156 M. LÖWY. As aventuras de Karl Marx contra o Barão de Münchhausen, 1987. 
teoria crítica dos direitos humanos com vistas à superação da contradição entre a miséria real e a garantia universal de direitos.

A legalidade, enquanto tal, paralisa as lutas sociais se não houver uma permanente mobilização para assegurar as aquisições dos planos político e moral e para ir além do positivado e dos instrumentos consagrados de interpretação ${ }^{157}$, os quais são hegemônicos nas instituições do Estado capitalista. A legalidade se erige sobre uma base material em que a vontade individual está secundarizada em relação aos imperativos da reprodução social. Os direitos humanos, neste contexto, aparecem em múltiplas dimensões (moral, política, jurídica...), expressando a ambiguidade destes direitos. Se a "moral" e a "política" que se tem em vista aqui são vistas também como campos de disputa dos sujeitos do trabalho, o discurso dos direitos humanos acaba por dar respaldo às lutas sociais na esfera jurídica enquanto realizam a ponte entre esta e as demandas emancipatórias.

A perspectiva de István Mészáros sobre os direitos humanos não se distancia da tradição marxista de análise do direito, a qual vê o direito como forma de uma relação social específica ${ }^{158}$, embora não desenvolva suas análises tanto no terreno da crítica imanente ao direito ${ }^{159}$. István Mészáros, de qualquer modo,

157 Como descreve T. MELO. Direito e Ideologia: um estudo a partir da função social da propriedade rural, 2009, p. 91, a respeito das restrições impostas pela interpretação, "O MST, contudo, parece não se abater pelo fato de que a reforma agrária está prevista em 'normas constitucionais de princípio programático', dentro da categoria das 'normas constitucionais de eficácia limitada'. Mais do que isso, parece não bastar para o movimento social que a norma tenha eficácia jurídica, ainda mais se a essa eficácia jurídica não é necessário corresponder efeitos concretos, palpáveis".

158 Visão esta apoiada no clássico estudo de E. B. PASUKANIS. A teoria geral do direito e $o$ marxismo, 1989.

159 Deve-se apontar que E. Pasukanis e I. Mészáros desenvolvem teorias em níveis diferentes de generalidade e de abrangência. Tal diferença se deve não apenas à direção que cada qual imprime em sua obra - uma sobre teoria geral do direito, outra com objetos filosóficos e sociológicos muito mais amplos - mas também ao fato de que a obra do jovem Marx veio à luz principalmente a partir da década de 1930 do século XX, obra esta na qual István Mészáros se apoia largamente, em explícito combate ao "marxismo ortodoxo soviético". Assim, enquanto E. Pasukanis deu os primeiros passos na crítica marxista da teoria geral do direito, apontando a estreita correlação entre a forma jurídica e a forma mercantil, seguindo a linha de argumentação de "O Capital", I. Mészáros, em suas diversas obras, se ocupou das superestruturas em geral, no âmbito das quais trata do fenômeno do direito, e tratou também da predominância das superestruturas jurídica e política no contexto capitalista e do modo como lidar com elas no seio de um complexo processo emancipatório. Assim, determinações da superestrutura jurídica e política que não aparecem na análise pasukaniana estão presentes em Mészáros e vice-versa. Com isto não se pretende afirmar que haja 
vê o direito como uma das mediações essenciais do sistema de mediações do capital. Com isso, acrescenta àquela tradição um chamado à contextualização das questões envolvidas na luta social, um chamado a remeter o método a seu fundamento substantivo, o que permite um exame mais aprofundado do papel do direito e dos direitos humanos para os sujeitos do trabalho. Ou seja, põe em perspectiva histórica os direitos humanos e permite a defesa, numa perspectiva marxista, de sua importância para a luta social - uma implicação positiva da crítica.

Isto é decorrência também de sua visão sobre o método como intimamente relacionado ao fundamento substantivo em que tal método se desenvolve. Daí que o lado ativo dos direitos humanos, ao ganhar relevo nas lutas sociais atuais, passe a ser uma questão teórica da maior relevância. Nas próprias lutas sociais emancipatórias os direitos humanos aparecem não como garantias positivadas ou como formalizações e ritualizações de necessidades, mas como busca da emancipação da sujeição às classes, busca da liberdade pessoal e das condições de não-anulabilidade da vontade individual.

O modo de aparecer dos direitos humanos como bandeiras de luta depende das condições existentes em três fases muito diferentes do desenvolvimento social - capitalismo, socialismo, comunismo - com papel diferenciado para tais direitos humanos em cada fase ${ }^{160}$.

Assim, István Mészáros afirma, verbis, que

"(1) sob as condições da sociedade capitalista, o apelo aos direitos humanos envolve a rejeição dos interesses particulares dominantes e a defesa da liberdade pessoal e da auto-realização individual, em oposição às forças de desumanização e de reificação ou de dominação material crescentemente destrutivas; (2) em uma sociedade de

discordâncias marcantes entre o pensamento de E. Pasukanis e I. Mészáros. Porém, como já observado, há uma significativa diferença de âmbito e de amplitude. Enquanto um trata da forma jurídica, o outro trata do direito no seio da análise das formas de consciência e das superestruturas, valendo-se de uma teoria das mediações. Enquanto um critica a teoria geral do direito, outro transita entre uma teoria da justiça (como ao discutir moral e legalidade em "Teoria da Alienação em Marx") e uma sociologia do direito (ao discutir largamente a questão superestrutura jurídica). Ou seja, os autores tratam de determinações diferentes do fenômeno jurídico, sendo marcante a influência da obra "O Capital" em E. Pasukanis, e de um conjunto mais amplo das obra de Marx, inclusive de obras da juventude deste, em I. Mészáros.

160 I. MÉSZÁROS. Marxismo e Direitos Humanos, 2008, p. 168. 
transição, os direitos humanos promovem o padrão que estipula que, no interesse da igualdade verdadeira, "o direito, ao invés de ser igual, teria de se desigual", de modo a discriminar positivamente em favor dos indivíduos necessitados, no sentido de compensar as contradições e desigualdades herdadas; (3) em uma 'fase mais adiantada da sociedade comunista', quando - sob a premissa do mais alto desenvolvimento proporcional a elas - a sociedade obtém, 'de cada um, de acordo com sua habilidade' e dá 'a cada um de acordo com as suas necessidades', a necessidade de aplicação de um padrão igual não existe mais, uma vez que o desenvolvimento completo de um indivíduo de modo algum interfere na auto-realização dos outros como indivíduos verdadeiros. Sob tais circunstâncias - quando a divisão do trabalho e o Estado estiverem efetivamente suplantados - a questão da efetivação de direitos (mesmo que sejam direitos humanos) não pode nem precisa emergir, uma vez que o 'livre desenvolvimento das individualidades' (que nas formas anteriores de desenvolvimento social incluindo a sociedade de transição, só poderia ser postulado de forma mais ou menos abstrata) é integrante do metabolismo social e atua como seu princípio regulador fundamental" ${ }^{161}$.

Esta visão inerentemente histórica permite visualizar o papel que devem cumprir os direitos humanos no contexto atual: não o de redenção de movimentos sociais emancipatórios, mas também não o de paralisação permanente das lutas em razão de demandas específicas que mal podem ser conquistadas, mas o de uma seta apontada para as continuadas conquistas emancipatórias e expansão da "autodeterminação interna" ou moral, a qual se torna uma força material quando empunhada pelos sujeitos do trabalho.

Daí a teleologia das lutas políticas de movimentos emancipatórios estar intimamente relacionada com a ideia de que a "igualdade deve ser medida pela capacidade do trabalhador e pela necessidade [carência] do consumidor, não pela intensidade do trabalho nem pela quantidade de mercadorias consumidas" ${ }^{162}$, nas palavras de Babeuf, lembradas por István Mészáros no ensaio "A liberação das mulheres: a questão da igualdade substantiva", que ecoaram em K. Marx na célebre passagem em que defende que, "numa fase superior da sociedade

161 Idem

162 PHILIPPE BUONARROTI, Conspiration pour l'égalité dite de Babeuf, 1828, p. 297, apud I. MÉSZÁROS. Para Além do Capital, 2002, p. 306/307. 
comunista (...) o limitado horizonte do direito burguês poderá ser definitivamente ultrapassado e a sociedade poderá escrever nas suas bandeiras: 'De cada um segundo as suas capacidades, a cada um segundo as suas necessidades!"'163

István Mészáros, como Marx, não despreza o papel do direito na sociedade. Os papéis ativo e ambíguo do direito devem ser levados em conta para a compreensão da medida em que o direito obstaculiza ou viabiliza a exploração e a dominação no contexto do capitalismo. A legalidade relaciona-se externamente com o ser humano como ser humano "abstratamente público", "mas nunca internamente com o verdadeiro indivíduo"164. A função da legalidade está em formular exigências a um indivíduo abstrato (que é enquadrado como contribuinte, empregado, segurado e assim por diante) e impor regras e sanções ${ }^{165}$ - "mas a legalidade - afirma Mészáros - não faz suas próprias normas, ela simplesmente as codifica, e desse modo está numa relação externa até mesmo com seu próprio conteúdo"166. Esta observação é importante porque explicita a inter-relação da superestrutura jurídica com a superestrutura política e também com a base material. A luta das classes trabalhadoras se desenvolve em todas estas dimensões interrrelacionadas da realidade social.

Observa-se que a legalidade é impotente, pois é "totalmente incapaz de transformar" as "'necessidades da sociedade' externas em necessidades internas do indivíduo real" ${ }^{167}$. Nem por isso Mészáros defende uma postura pessimista: não se pode esperar da legalidade aquilo que ela não pode fazer, embora se deva ter consciência das suas verdadeiras potencialidades (e, portanto, das suas limitações). Nos precisos termos de Mészáros: "No entanto, essa impotência mutuamente condicionante [da legalidade e da moral] não nos deve levar a conclusões pessimistas. Ao contrário: ela apenas mostra que é absurdo esperar de qualquer uma das duas aquilo que nenhuma delas pode fazer, e isso nos torna mais conscientes das verdadeiras potencialidades de ambas..."168.

163 K. MARX. Crítica ao Programa de Gotha. In R. ANTUNES. A dialética do Trabalho. Escritos de Marx e Engels, 2004, p. 110.

164 I. MÉSZÁROS. A Teoria da Alienação em Marx, 2006, p. 170.

165 Idem, p. 171.

166 Idem.

167 Idem.

168 Idem. 
A visão de István Mészáros sobre a moral o aproxima de uma tradição filosófica marxista que prega a superação da alienação moral pelo desenvolvimento de uma nova moral ${ }^{169}$. Assim, por exemplo, Henri Lefebvre afirma que "é absolutamente falso atribuir ao marxismo senão que uma posição negativa e crítica diante do problema da moral... O marxismo afirma que é necessário criar hoje uma nova ética, liberta da alienação moral e da ilusão ideológica"170. E a superação da alienação humana, na teoria marxiana, só pode ser levada a cabo pelo proletariado. Assim também a alienação moral. Daí que a moral a que se refere tal tradição do marxismo dever ser concebida como uma moral classista, apoiada numa renovada ideia de ser humano e de humanismo, às quais se atribui um sentido concreto ${ }^{171}$, histórico, dialético e materialista.

Com base na ideia de que as normas existem antes mesmo de qualquer codificação legal "como necessidades essenciais ao funcionamento da sociedade" ${ }^{\text {"172, }}$, apenas com a defesa da autodeterminação do ser humano seria possível combater a legalidade externa, a legalidade abstrata, que é aquela da qual emanam normas que não dizem respeito ao ser humano concreto, mas ao ser humano idealizado e necessário para certo modo de reprodução social. A legalidade externa é adequada ao funcionamento de uma economia capitalista e se contrapõe à forma de autogestão do ser humano concreto.

Neste ínterim, a moral teria papel fundamental, já que se trata de defender uma legalidade que preste contas à moral (não a uma moral abstrata qualquer, mas a uma moral classista), com o que se submeteria a juridicização da vida social a uma crítica permanente, na busca pela superação da superestrutura jurídica e pelo advento de uma superestrutura alternativa.

Observe-se, ainda, que a necessidade interior do ser humano não se confunde com um "dever moral" externamente imposto: "A existência da lei é... a prova prática da impotência da moral com respeito a isso"173.

Conclui-se, assim, que a legalidade separada da moral fica completamente destituída de conteúdo e justificação, tornando-se, "ao menos potencialmente, um

169 Neste sentido, H. Lefebvre, Le Marxisme, 2006, p. 49 e ss.

170 Idem, 53.

171 Idem, p. 58/59.

172 I. MÉSZÁROS. A Teoria da Alienação em Marx, 2006, p. 171.

173 Idem. 
instrumento fácil para as determinações mais arbitrárias". É este o caso do positivismo e formalismo jurídicos, cujo combate por correntes antipositivistas (mas não necessariamente críticas) de forma recorrente já aponta para o afastamento em relação à moral. Positivismo e formalismo, como medidas externas, impõem-se, no máximo, veiculando uma moral também externa (e este é o caso inclusive das correntes antipositivistas e não críticas, estranha à autodeterminação humana).

Entretanto,

"Não basta indicar na lei a aparência 'reificada' dos ideais morais' que se tornaram possibilidades práticas, por intermédio do funcionamento complexo dos múltiplos órgãos da moral, para a vasta maioria da sociedade - o que faz possível a sua codificação. Devemos também sublinhar que esta 'fixação', por mais reificada que seja, permite à moral não partir novamente do zero, mas começar da média codificada, tomada como novo ponto de partida"174

Assim, a importância da codificação, apesar do formalismo que a envolve, é externa a ela: é que a moral seja capaz de acrescentar o conteúdo codificado às suas pautas para avançar com relação à codificação. A codificação se coloca como um dado histórico sujeito às mais diversas contradições da existência social - não se trata de uma determinação histórica unilateral e unidirecional, embora possa o ser em seu princípio, que é o momento da cristalização, portanto da acomodação, de demandas sociais que potencialmente confrontam a ordem sociometabólica e o próprio direito. As preocupações internas da teoria do direito, assim, devem envolver levar a sério a moral, evitando a arbitrariedade - ademais oculta pelo próprio formalismo, que legitima pelo procedimento as decisões arbitrárias - e qualificando os pontos de partida da moral - os quais não estão postos em nenhuma ética metafísica, mas nas condições reais de vida dos trabalhadores.

No que se refere à relação entre legalidade e moral, observa István Mészáros que

"não poderia haver progresso humano sem essa influência mutuamente condicionante entre as duas. Enquanto a moral 
sem a legalidade é simples desejo quixotesco, ou uma suposição abstrata transcendental, a legalidade sem seu conteúdo dinâmico é apenas uma moldura arbitrária que permite a substituição das necessidades parciais, voluntaristas, pelas necessidades da sociedade existente" ${ }^{175}$.

Na medida em que "a moral sem a legalidade é simples desejo quixotesco, ou uma suposição abstrata transcendental" e "a legalidade sem seu conteúdo dinâmico é apenas uma moldura arbitrária que permite a substituição das necessidades parciais, voluntaristas, pelas necessidades da sociedade existente", moral e direito devem ser levados em conta conjuntamente pela crítica se se espera algum alcance transformador daquelas pautas morais veiculadas pelos sujeitos do trabalho.

Neste quadro,

"O que deve se combatido não é a salvaguarda legal de um certo nível de aquisições no plano moral, mas seu divórcio do homem, que resulta de uma forma reificada de 'fixação' (pode haver muitas formas de instituições legais cujas potencialidades devam ser constantemente exploradas tendo em vista uma crescente humanização da legalidade. Uma dessas formas é a que é chamada de 'democracia direta': virtualmente uma 'terra virgem' para os esforços práticos desse tipo)"176.

Esta crítica de István Mészáros à legalidade converge com a crítica feita aos direitos humanos em "Marxismo e Direitos Humanos", na medida em que são apontadas as limitações da legalidade no contexto dado, sem desprezar as relações dialéticas existentes e ressaltando o papel do combate às formalizações, às formas reificadas de fixação das aquisições das lutas sociais.

István Mészáros defende então que "aqueles que defendem a abolição de todas as normas e sanções confundem 'medida' com medida externa. Esquecemse da medida humano-natural e, por isso, interna: o próprio homem. Só com base nessa medida é possível definir adequadamente o progresso humano como um 
recuo sem fim da legalidade externa e um aumento correspondente da autodeterminação interna, ou moral" ${ }^{177}$. Em outros termos, desprezam os problemas da superestrutura enquanto tal e da regulação consciente e comunitária do intercâmbio do ser humano com a natureza, confundindo aquela superestrutura com a superestrutura jurídica.

Assim, István Mészáros defende, na verdade, a autodeterminação, a qual só pode ser uma tarefa interna do ser humano, no sentido de desenvolvimento pleno de suas potencialidades no contexto social em que se encontra: "Essa tarefa não pode ser realizada para o homem senão pelo próprio homem", pelo órgão da moral "como automediação do homem em sua luta pela autorealização", que é a educação ${ }^{178}$.

Não se trataria, assim, de defender a abolição de todas as normas e sanções, mas de defender a autodeterminação interna (moral) ${ }^{179}$, que tem como medida o próprio ser humano - e este seria o parâmetro teórico para 0 desenvolvimento do estudo da superestrutura enquanto tal. A autodeterminação, como tarefa interna do ser humano, "não pode ser realizada para o homem senão pelo próprio homem", o que deveria ser feito por meio da educação, o único órgão possível de automediação humana. Apenas na relação da autoeducação seria possível "conceber a superação da mera exterioridade na totalidade das atividades vitais do homem - inclusive, não a abolição total, mas a crescente

177 Idem. István Mészáros utiliza o termo "medida", o qual pode ser entendido como "padrão" e, na tradição filosófica, tem um significado técnico específico. Como exposto no verbete respectivo em N. ABBAGNANO, Dicionário de Filosofia, 2007, p. 656 "Já Platão havia dividido a arte da $M$. em duas partes, situando na primeira as artes 'que medem o número, o comprimento, a altura, a largura e a velocidade em relação a seus contrários' e na segunda 'as artes que medem a relação ao justo meio, ao conveniente, ao oportuno, ao obrigatório, enfim ás determinações que estão no meio entre dois extremos'... Conseqüentemente podese entender por medida: (...) 2 Critério ou o cânon daquilo que é verdadeiro ou bem. Nesse sentido, Cleóbulo, um dos Sete Sábios, dizia: 'O melhor é a M.' (DIÓG. L, 1, 93) - Platão via na justa M. a ordem e a harmonia das coisas (Fil., $24 \mathrm{c}-\mathrm{cl}$ ) e para Aristóteles o meio (v.) era o cânon da virtude ética. No mesmo sentido essa palavra foi usada por Protágoras, em seu famoso princípio de que o homem é a M. das coisas, e por Aristóteles, quando via no homem virtuoso 'o cânon e a M. das coisas' (Et. nic, III, 4, 1113 a 33). Nesse sentido, a M. é um dos conceitos fundamentais da cultura clássica grega".

178 I. MÉSZÁROS. A Educação Para Além do Capital, 2005, p. 77. Vide na próxima página citação literal do trecho ora referido.

179 Novamente ressalte-se: a noção de medida interna não tem qualquer inspiração jusnaturalista; tem fundamento isto sim na noção de natureza humana apresentada no início do capítulo, claramente inspirada na tradição marxista. 
transcendência da legalidade externa" ${ }^{\prime 180}$.

Assim, o problema da legalidade não é que ela meramente positiva e petrifica, ao submeter a seu formalismo, aquisições do plano moral ${ }^{181}$, mas o afastamento dela dos problemas sociais reais, decorrente de uma forma reificada de fixação. A superação da mera exterioridade, "devido às condições necessárias a ela, não pode ser concebida simplesmente como um ponto estático da história para além do qual começa a 'idade de ouro', mas somente como um processo contínuo, com realizações qualitativamente diferentes em suas várias fases" ${ }^{182}$. Esta lembrança acerca das realizações qualitativamente diferentes nas várias fases do processo contínuo de superação da mera exterioridade encontra sua expressão na discussão sobre o desenvolvimento dos direitos humanos nas diversas fases do desenvolvimento social ${ }^{183}$.

Abra-se espaço para uma digressão neste ponto: a crítica ao direito e aos direitos humanos não deve levar a uma leitura fetichizante da política e ao consequente desprezo pela compreensão do papel do direito nas lutas sociais ${ }^{184}$. Marx aponta o direito como forma inerente ao capitalismo, o que não significa que

180 I. MÉSZÁROS. A Teoria da Alienação em Marx, 2006, p. 171. O desenvolvimento pedagógico de uma tal concepção pode ser visto, por exemplo, em P. FREIRE, Pedagogia do Oprimido, 2007.

181 Idem.

182 Idem.

183 Conforme a já citada referência a I. MÉSZÁROS. Marxismo e Direitos Humanos, 2008, p. 168.

184 Neste sentido, necessário tratar da questão da emancipação como um problema complexo atinente à totalidade da vida produtiva humana, não como uma questão a ser resolvida meramente no campo da "política". Este campo também pode obnubilar relações de exploração, como o direito, segundo M. B. NAVES. Marxismo e Direito - um estudo sobre Pachukanis, 2000, o faz: a "operação jurídica impede que a relação de capital seja percebida como relação de exploração da força de trabalho". Desvendar a essência existente concomitantemente com a aparência implica em perceber que há na política um campo de luta de classe que se desenvolve de forma ferrenha, mas que também há no direito tal campo de luta. Disputas ideológicas no interior do direito são tão mais frequentes quanto mais as classes trabalhadoras se apropriam do discurso jurídico e compreendem as funções da esfera do direito na luta de classes. Por isso, é cristalino que não é pela "liberdade burguesa" que lutam os movimentos operários; também os movimentos de direitos civis mais diversos mulheres, negros, etc - não lutam necessariamente apenas por tal "liberdade burguesa". Os elementos de subversão da ordem nas lutas por uma liberdade substantiva, em suas mais diversas matrizes, não podem ser desprezados no estudo dos direitos humanos. Assim, a compreensão das ambiguidades e contradições, tanto do direito quanto da política, deve estar na agenda dos referidos movimentos sociais. Tal está longe de significar a defesa de um "reformismo jurídico" - ao contrário, busca afirmar o papel da tática jurídica, aprofundar a crítica à esfera do direito, sem perder de vista a orientação estratégica. 
despreze as tarefas imediatas referentes às lutas por direitos humanos. Sua crítica anterior aos "direitos do homem", no sentido de que tais direito não podem levar à emancipação humana ${ }^{185}$, já esclarecera tal questão. A importância da tática para o êxito estratégico é colocado de forma precisa por István Mészáros:

\begin{abstract}
"Nesse empreendimento [de transformação social emancipadora], as tarefas imediatas e as suas estruturas estratégicas globais não podem ser separadas ou opostas umas às outras. O êxito estratégico é impensável sem a realização das tarefas imediatas. $\mathrm{Na}$ verdade, a própria estrutura estratégica é a síntese global de inúmeras tarefas imediatas, sempre renovadas e expandidas, e desafios. Mas a solução destes só é possível se a abordagem do imediato for orientada pela sintetização da estrutura estratégica. Os passos mediadores em direção ao futuro - no sentido da única forma viável de automediação - só podem começar do imediato, mas iluminados pelo espaço que ela pode, legitimamente, ocupar dentro da estratégia global orientada pelo futuro que se vislumbra" ${ }^{186}$.
\end{abstract}

Assim, tarefas táticas e estratégicas sequer podem ser separadas, o que significa que uma depende ou decorre da outra - em suma "a própria estrutura estratégica é a síntese global de inúmeras tarefas imediatas, sempre renovadas e expandidas, e desafios", não há uma estrutura estratégica separada ou contraposta às tarefas imediatas. As implicações teóricas de tal impossibilidade de separação devem ser bem equacionadas no campo da crítica ao direito. Não se pode valer-se de uma crítica externa que se cale quando se trata de discutir questões da ciência positiva. Neste sentido, realizar uma crítica marxista ao direito precisa implicar também em realizar uma crítica também aos instrumentos dogmáticos de que se valem os juristas, ainda que tais instrumentos apareçam com roupagens de progressismo, como as correntes "pós-positivistas".

A necessidade da fundamentação teórica surge nos diversos âmbitos em que os direitos humanos devem ser defendidos no interesse dos sujeitos do trabalho e a ausência desta fundamentação implica na rendição a esquemas, porque sistematizados, aparentemente mais racionais, mas que não respondem plenamente àquele interesse. Daí a necessidade de uma metodologia crítica dos direitos humanos, uma metodologia que não apenas faça a indispensável 
denúncia do formalismo jurídico, mas que aponte para uma fundamentação crítica das demandas das lutas sociais que se apoiam em direitos humanos. Numa análise crítica desta categoria, não se deixa de encontrar contradições, mas estas contradições decorrem do próprio modo como a luta social se dá, no confronto entre os sujeitos do trabalho e do capital.

A leitura de István Mészáros não leva a uma análise "interna" do direito, a um exame da dogmática dos direitos humanos, mas apenas a desenvolvimentos no âmbito da filosofia do direito. Daí porque não se trata de partir dos conceitos mais elementares do direito e criticar a operacionalidade das teorias dogmáticas, embora indicações sobre isto possam ser apontadas, como, por exemplo, no uso de categorias como igualdade substantiva. Trata-se, isto sim, de oferecer uma visão totalizante da categoria "direitos humanos", dando especial ênfase à compreensão sobre o modo como os sujeitos do trabalho lidam com tal categoria atualmente.

Uma análise crítica da categoria de direitos humanos a apresenta como contraditória justamente por causa do uso que os movimentos sociais fazem de tal categoria - não o fazem como que se submetendo às concepções dominantes, mas apresentando alternativas a estas concepções, subvertendo-as. Empunhar a bandeira de luta dos direitos humanos não implica necessariamente na mera redenção ao sistema estatal que promete direitos e garantias. Como linguagem específica encontrada na atualidade para levar a cabo a luta social, os direitos humanos evocados pelos sujeitos do trabalho mantêm uma relação estrutural com os interesses destes sujeitos.

Destarte, não se poder dizer que os direitos humanos não têm papel algum na busca por transformações sociais ou que seu papel é apenas petrificar e obstar esta busca. A questão deve ser colocada em seus devidos termos: o direito não é protagonista de transformações sociais e normalmente tende a consolidar e formalizar transformações anteriores; justamente o fato de o direito ensimesmarse em suas abstrações, em sua seletividade fática e valorações hegemônicas, leva a que não possa haver protagonismo algum. Mas isto não implica que os direitos humanos devam ser vistos como mero aparato que obstaculiza demandas sociais, como um aparato sem qualquer papel no desenvolvimento das demandas dos sujeitos do trabalho, que no contexto atual acabam se expressando 
crescentemente neste modus jurídico. 


\section{CONCLUSÕES}

A partir do quanto exposto neste trabalho, conclui-se que, em István Mészáros, a questão dos direitos humanos é uma questão de grande relevância para o marxismo, devendo ser compreendida em cada fase do desenvolvimento social (capitalismo, sociedade de transição, comunismo). István Mészáros desenvolve uma crítica externa aos direitos humanos, não se tratando de uma crítica imanente do direito (como a feita, por exemplo, por Eugeny Pasukanis), mas de uma crítica que se desenvolve no âmbito de uma obra que engloba diversos problemas filosóficos, sociológicos, econômicos, políticos e jurídicos.

Verificou-se que, ao tratar de conceitos de direitos humanos, como "igualdade substantiva", István Mészáros transita pela seara política, utilizando-os como conceitos fundamentais para lutas sociais que se desenvolvem no contexto atual. De fato, tais conceitos expressam aquilo que seria possível, dadas as condições materiais existentes hoje, alcançar por meio de uma alteração radical e necessária da ordem produtiva vigente. Assim, confere conteúdo político a conceitos que, no âmbito da teoria geral do direito, se mostram como formas jurídicas necessárias ao metabolismo do capital. Neste sentido, segue os passos do próprio Marx, que, como visto, ao tratar da questão dos "direitos do homem" desenvolveu principalmente questões de ordem política e apenas marginalmente de ordem lógica.

Poder-se-ia questionar se tal forma de proceder não levaria a ilusões com as potencialidades dos direitos humanos. A resposta, no quadro teórico apresentado por István Mészáros, só pode ser negativa, uma vez que, como visto, este quadro teórico é vigoroso, distinguindo a forma de utilização de tais direitos nas lutas sociais em cada fase do desenvolvimento social, inclusive com a distinção entre superestrutura jurídica e superestrutura em si. Em razão disto, em momento algum se é levado a crer numa "panaceia dos direitos humanos", mas, ao mesmo tempo, não se despreza que, numa sociedade de transição os temas dos direitos humanos deverão ser objeto de preocupação específica dos produtores associados, rumo a uma ordem produtiva que implique no livre desenvolvimento das individualidades.

Não obstante este vigoroso desenvolvimento, István Mészáros mantêm-se 
num nível de abstração elevado quando trata de questões atinentes à superestrutura jurídica e aos direitos humanos, o que talvez decorra das próprias dificuldades do fundamento substantivo no qual se apoia Mészáros, das próprias dificuldades práticas dos movimentos emancipatórios em tal questão. Mesmo quando trata da questão dos direitos humanos das mulheres, por exemplo, apenas exemplos muito genéricos são dados, faltando concretude na análise. Isto leva a que a questão dos direitos humanos em István Mészáros transite muito mais pela seara política que pela análise jurídica imanente.

Observou-se na Introdução a este trabalho que a motivação para o presente estudo decorria da insuficiência das teorias críticas dos direitos humanos para a fundamentação das lutas sociais e dos movimentos que empunham as bandeiras de direitos humanos. Assim, buscou-se, com a leitura de István Mészáros, identificar elementos que contribuíssem para aprofundar esta relação entre teoria dos direitos humanos e sua fundamentação. Pode-se concluir que a fundamentação dos direitos humanos vislumbrada por István Mészáros é política, decorrendo estes direitos das próprias necessidades humanas reprimidas pelo sistema sociometabólico do capital. Em razão deste modo de fundamentar os direitos humanos, o discurso e a prática dos movimentos reivindicatórios podem ser vistos como portadores de potencial emancipatório, pois dotados de conteúdo político, não apenas jurídico.

As lutas sociais envolvem contradições concretas que ocasionam contradições discursivas, como as relativas à defesa ou não dos direitos humanos. Estes são vistos não raro com desconfiança e até como pautas que atrapalham os objetivos últimos das lutas sociais emancipatórias. Mas também são vistos como bandeiras táticas necessárias ou até mesmo como fim último da luta social.

De lado os argumentos que podem sustentar cada uma destas posições, neste trabalho se apontou que os direitos humanos são bandeiras táticas de grande relevância e que assim devem ser reconhecidos, levando-se em conta as fases do desenvolvimento social. A partir disto, dando substância à mencionada motivação, a questão que se coloca é sobre qual o substrato teórico adequado para tratar destas bandeiras táticas, ou ainda sobre qual o papel da crítica na análise das lutas sociais que empunham tais bandeiras. A leitura de István 
Mészáros, assim, esteve guiada por esta questão e apontou, nos capítulos 3 a 6 , o modo como a sua análise e a sua argumentação sobre os direitos humanos se desenvolvem em diversos de seus textos, apresentando um substrato teórico relevante para a compreensão de tais direitos.

Isto porque se defende a necessidade de se conceber uma metodologia ou uma teoria crítica dos direitos humanos do ponto de vista dos sujeitos sociais do trabalho ou movimentos sociais emancipatórios ${ }^{187}$, de modo que, por meio do entendimento das limitações decorrentes do sistema sociometabólico do capital, os direitos humanos possam ser defendidos com a devida ênfase. É dizer, buscase problematizar se a teoria crítica teria algo a enunciar quando se trata de defender direitos humanos, ou se em tal defesa os movimentos sociais apenas poderiam se valer das teorias jurídicas tradicionais.

A crítica de István Mészáros ao direito explicita que a superestrutura jurídica se desenvolve em consonância com a infraestrutura econômica, e tal crítica é levada a suas últimas consequências ao se desenvolver como uma metodologia para a análise dos direitos humanos que não apenas os descrevem abstratamente, mas que apontam, ao mesmo tempo, os seus limites num dado contexto. É dizer, István Mészáros não apenas descreve a categoria direitos humanos, mas também oferece ferramentas para a análise da realidade em que tais direitos aparecem como reivindicações inclusive de movimentos sociais emancipatórios. $O$ autor desenvolve assim uma metodologia que leva em conta a necessária historicidade da normatividade alienada (medida externa) e que se apoia nas mediações primárias para viabilizar que, no momento adequado, possa ser proposta uma alternativa superestrutural viável ao novo contexto (medida interna, autodeterminação).

Assim, os direitos humanos, tais como aparecem atualmente na prática dos sujeitos do trabalho envolvidos nas lutas sociais, são parte de uma alternativa hegemônica no âmbito da superestrutura, isto é, despontam como o discurso de uma prática que se contrapõe ao da superestrutura jurídica e política alienada. Como corolário, pode-se afirmar que os direitos humanos são parte da definição de uma alternativa positiva ao sistema sociometabólico do capital, não podendo ser desprezados pela luta social. Posto nestes termos, não se está a tratar da

187 Vale aqui retomar a observação feita na nota de rodapé n. 1. 
categoria de direitos humanos enquanto abstração, enquanto mera forma jurídica, mas enquanto portadores de conteúdo político, por assim dizer, direitos humanos concretos. Por isso se afirma que a luta por direitos humanos, no contexto atual, pode forçar as contradições no Estado e no sistema de mercado excludentes, pode se tornar uma força material se os movimentos sociais deles se apoderassem adequadamente - e adequadamente, aqui, só pode significar de maneira crítica.

$\mathrm{Na}$ análise empreendida nesta dissertação, buscou-se estabelecer elementos para a reflexão crítica sobre os direitos humanos, desenvolvendo-se seis capítulos, assim organizados:

Os dois primeiros capítulos estão inseridos na Parte I do trabalho, que busca dar um panorama geral sobre o pensamento de István Mészáros, adentrando especificamente nas suas concepções sobre a superestrutura jurídica.

Assim, no Capítulo 1 realizou-se um resumo geral sobre o pensamento de István Mészáros e no Capítulo 2 se estudou a relação entre estrutura social e superestrutura jurídica, abordando-se as questões do papel ativo da superestrutura, da expansão da superestrutura jurídica nos dias atuais e da problemática da superação desta superestrutura. Daí a constatada importância de um exame crítico adequado da superestrutura jurídica e das alternativas propostas pelos movimentos sociais envolvidos nas tendências objetivamente em desdobramento da transformação histórica.

No Capítulo 3 discutiu-se o distanciamento entre a teoria dos direitos humanos e o método crítico marxista, partindo-se do exame da abordagem marxiana sobre a filosofia, a qual era criticada em razão do seu distanciamento em relação ao mundo real. Esta crítica tem paralelo com a feita aos "direitos do homem", seja quando se constata que tais direitos são unilaterais, são os do "homem egoísta", "separado da comunidade", que "não se baseia na vinculação do homem com os demais homens" e reflete a contradição entre desigualdade privada e igualdade pública, entre desigualdade substantiva e igualdade formal ("Sobre a Questão Judaica"), seja quando se realiza a crítica ao unilateralismo metódico que remete conceitos de liberdade, igualdade e equidade a uma esfera abstratamente jurídica, sem considerar as relações econômicas e sociais efetivamente existentes ("Crítica ao programa de Gotha"). Propugnou-se também 
por uma perspectiva crítica "positiva" o que envolve buscar o que nos direitos humanos postos nas pautas de movimentos sociais está somando para a superação da superestrutura jurídica existente. A importância desta perspectiva está justamente em discutir a própria fundamentação teórica das lutas imediatas dos sujeitos do trabalho.

Nos capítulos 4 a 6 foram discutidas as linhas mestras da abordagem de István Mészáros no texto "Marxismo e Direitos Humanos", conformando o caminho percorrido por este filósofo numa metodologia crítica dos direitos humanos.

No Capítulo 4 abordou-se a contradição entre a enunciação de garantias de direitos humanos e a ineficácia de tais direitos. A crítica de natureza não lógica, mas histórica, de que os "direitos do homem" são utilizados como "racionalizações pré-fabricadas das estruturas predominantes de desigualdade e dominação" ${ }^{188}$, deixa aberta a via para que os direitos humanos sejam vistos como direitos contraditórios, ao mesmo tempo como dominação e como resistência. Ao se expressarem como resistência, estes direitos aparecem como instrumentos de deslegitimação política e mantêm as condições superestruturais de uma transformação emancipatória - bem entendido, os direitos humanos empunhados pelos sujeitos do trabalho mantêm acesa a possibilidade da transformação superestrutural exigida ${ }^{189}$. Metodologicamente, o que se demonstrou foi que neste passo se realiza uma análise contextual (histórica) acerca de quais são os direitos garantidos, de qual a condição de vida dos supostos destinatários destes direitos, e quais as reivindicações e as formas de luta que estes levam adiante.

No Capítulo 5 apontou-se como passo metodológico a avaliação do sistema de direito, ressaltando a importância do controle do domínio jurídico numa perspectiva crítica que evite os problemas de ilusões jurídicas, confrontando as conceituações "oficiais" dos direitos humanos com as conceituações adequadas a superar as contradições inerentes a este discurso. Tratou-se, assim, de apresentar a necessidade de uma crítica específica, de natureza lógica, às concepções jurídicas dominantes que obstam a efetividade dos direitos humanos ou o avanço de garantias de direitos em dado contexto.

188 I. MÉSZÁROS. Marxismo e Direitos Humanos, 2008, p. 161.

189 O capítulo 4 de Estrutura Social e Formas de Consciência II, "Transformações materiais e Formas Ideológicas" é de grande valia para esta discussão. 
Por fim, no Capítulo 6 se desenvolveu uma discussão central para 0 trabalho: o modo como a busca das condições de não-anulabilidade da vontade individual se relaciona com o papel do direito nas lutas sociais. Por um lado, discutiu-se como a emancipação humana, o desenvolvimento livre das individualidades e as condições para a autorrealização humana são elementos teóricos que atravessam axiologicamente toda a obra de Marx e que decorrem do próprio modo como os movimentos sociais expressam suas lutas por direitos humanos. Por outro lado, asseverou-se que, embora não se possa esperar da legalidade aquilo que ela não pode fazer (isto é, conduzir à emancipação humana), deve-se ter consciência das suas verdadeiras potencialidades (e, portanto, das duas limitações), de modo que o combate crítico aos direitos humanos não envolve atacar a "salvaguarda legal de um certo nível de aquisições no plano moral, mas seu divórcio do homem, que resulta de uma forma reificada de 'fixação'"'190.

A questão da emancipação humana é uma questão prática complexa que envolve a superação das estruturas alienantes do sistema do capital. Os programas emancipatórios devem envolver as mais diversas esferas de tal sistema, devem envolver a crítica a todas as mediações de segunda ordem alienantes que impedem o livre desenvolvimento das individualidades, inclusive as jurídicas.

Há algumas décadas, marxismo e direitos humanos eram vistos como discursos contrapostos. $\mathrm{Na}$ fase descendente do capitalismo, porém, o discurso emancipatório dos direitos humanos torna-se cada vez mais incompatível com as exigências da expansão do capital. Assim, resta o desafio de, no contexto atual e num contexto de transição, utilizar-se da vigorosa filosofia de István Mészáros para desenvolver a crítica da superestrutura jurídica e os contornos da superestrutura necessária à renovada ordem social metabólica que se desenvolverá. 


\section{BIBLIOGRAFIA}

ABBAGNAMO, Nicola. Dicionário de Filosofia, São Paulo: Martins Fontes, 1998.

ALMEIDA, Silvio Luiz de. Reflexões sobre 'Legalidade e Ilegalidade' em História e Consciência de Classe. In http://www.unicamp.br/cemarx/ anais_v_coloquio_arquivos/arquivos/comunicacoes/gt1/sessao6/Silvio_Alm eida.pdf, consultado em 22 de fevereiro de 2012.

ALMEIDA, Silvio Luiz de. O direito no jovem Lukács: a filosofia do direito em História e Consciência de Classe. São Paulo: Alfa-Ômega, 2006.

ALTHUSSER, Louis. Pour Marx. Paris: La Découverte, 2005.

AMERIKS, Karl. The legacy of idealism in the philosophy of Feuerbach, Marx, and Kierkegaard, In K. AMERIKS (Ed.). The Cambridge Companion to German Idealism. Cambridge: Cambridge, 2000.

ANTUNES, Ricardo. A dialética do Trabalho. Escritos de Marx e Engels. São Paulo: Expressão Popular, 2004.

ANTUNES, Ricardo. Adeus ao trabalho? Ensaio sobre as metamorfoses e a centralidade do mundo do trabalho. $7^{\mathrm{a}}$ ed., São Paulo: Cortez, 2000.

BEER, Max. História do Socialismo e das Lutas Sociais. São Paulo: Expressão Popular, 2006.

BOBBIO, Norberto. A Era dos Direitos. Trad. Carlos Nelson Coutinho. Rio de Janeiro: Campus, 1992. 
BOTTOMORE, Tom (ed.), A dictionary of marxist thought, Oxford: Blackwell, 1991.

CAFFÉ ALVES, Alaôr. Estado e Ideologia - Aparência e Realidade. São Paulo: Brasiliense, 1987.

CANOTILHO, José Joaquim Gomes, CORREIA, Marcus Orione Gonçalves, CORREIA, Érica Paula Barcha. Direitos Fundamentais Sociais. São Paulo: Saraiva, 2010.

CARVER, Terrell. Marx - and Hegel's Logic. Political Studies, Vol. XXIV, n. 1 (57-68).

CARVER, Terrell. The Cambridge Companion To Marx. Cambridge: Cambridge, 1991.

COMPARATO, Fábio Konder. A afirmação histórica dos Direitos Humanos. 6ª Ed. São Paulo, Saraiva, 2008.

COTTINGHAM, JONH (Ed.), The Cambridge Companion to Descartes. Cambridge: Cambridge, 1992.

CORREIA, Marcus Orione Gonçalves. Por uma metodologia dos direitos humanos - uma análise na perspectiva dos direitos sociais. Revista do Departamento de Direito do Trabalho e da Seguridade Social da Faculdade de Direito da USP, São Paulo, v. 2, n. 4, jul./dez. 2007, pp. 119/149.

DORLIN, Elsa (coord.). Sexe, Race, Classe - Pour une Épistémologie de la Domination. Paris: PUF, 2009. 
DUMÉNIL, Gérard, LÖWY, Michel, RENAULT, Emmanuel. Lire Marx. Paris: PUF, 2009.

FAUSTO Ruy. Dialética Marxista, Dialética Hegeliana - O Capital e a Lógica de Hegel. R. Discurso (20), 1993, 41-77.

FAUSTO, Ruy. Marx: Lógica e Política: investigações para uma reconstituição do sentido da dialética. Tomo I. 2ª ed. São Paulo: Brasiliense, 1987.

FAUSTO, Ruy. Marx: Lógica e Política: investigações para uma reconstituição do sentido da dialética. Tomo II. São Paulo: Brasiliense, 1987.

FERRAZ JR., Tércio Sampaio. A Ciência do Direito. São Paulo: Atlas, 2006.

FERRAZ JR., Tércio Sampaio. Introdução ao Estudo do Direito. Técnica, Decisão, Dominação. 4ํㅡㄹ. Edão Paulo: Atlas, 2003.

FOSTER, Michael. Hegel's dialectical Method, in F. C. BEISER (ed.). The Cambridge Companion To Hegel, Cambridge: Cambridge, 1993.

FREIRE, Paulo. A Pedagogia do Oprimido. 46르 Ed. Rio de Janeiro: Paz e Terra, 2007.

GREEN, James N. Além do Carnaval - A Homossexualidade Masculina no Brasil do século XX. São Paulo: UNESP, 2000.

HARVEY, David. O enigma do Capital e as Crises do Capitalismo. São Paulo: Boitempo, 2011. 
HEGEL, Georg Whihelm Friedrich. A Fenomenologia do Espírito. Parte I. Tradução Paulo Meneses. 2ª Ed. Petrópolis: Vozes, 1992.

HEGEL, Georg Whihelm Friedrich. Science of Logic. Disponível em http://www.marxists.org/ reference/archive/hegel/works/hl/hlconten.htm.

HEGEL, Georg Whihelm Friedrich. Encyclopaedia of the Philosophical Sciences. Disponível em http://www.marxists.org/reference/archive/hegel /works/sl/sl_divis.htm.

HOBSBAWN, Eric. J. História do Marxismo. O marxismo no tempo de Marx. Vol. 1, 3를. Rio de Janeiro: Paz e Terra, 1987.

HOULGATE, Stephen. The Opening of Hegel's Logic. From Pure Being to Infinite. West Lafayette: Purdue University Press, 2006.

HUDIS, Peter., Conceptualizing an Emancipatory Alternative: István Mészáros's Beyond Capital, In Socialism and Democracy, Vol. 11:1, 1997, p. 37-53.

JINKINGS, Ivana, NOBILE, Rodrigo, István Mészáros e os Desafios do Tempo Histórico. São Paulo: Boitempo, 2011.

KOJÈVE, Alexadre. Introdução à Leitura de Hegel. Rio de Janeiro: Contraponto/UERJ, 2002.

KONDER, Leandro. Hegel - A Razão quase enlouquecida. Rio de Janeiro: Campus, 1991.

LEFEBVRE, Henri. Le Marxism. 23르 ed. Paris: PUF, 2006. 
LONGUENESSE, Béatrice. Hegel's Critique of Metaphysics. Trad. Nicole J. Simek. Cambridge: Cambridge, 2007.

LOSURDO, Domenico. A Tradição liberal e a construção histórica do conceito universal de homem. In Liberalismo. Entre Civilização e Barbárie. São Paulo: Anita Garibaldi, 2006.

LÖWY, Michel. As aventuras de Karl Marx contra o Barão de Münchhausen - marxismo e positivismo na sociologia do conhecimento. 4르 ed. São Paulo: Busca Vida, 1987.

LUKÁCS, György. História e Consciência de Classe. São Paulo: Martins Fontes, 2003.

LUKÁCS, György. Historia y consciencia de clase. Estudios de dialéctica marxista. México: Grijalbo, 1969.

LUKÁCS, György. Prolegômenos Para uma Ontologia do Ser Social. São Paulo: Boitempo, 2010.

MARTINELLI, Mário Eduardo. A deterioração dos Direitos de lgualdade Material no Neoliberalismo. Campinas: Millennium, 2009.

MARX, Karl. A Guerra Civil na França. In A Revolução Antes da Revolução. São Paulo: Expressão Popular, 2008.

MARX, Karl. A Miséria da Filosofia. São Paulo: Ícone, 2004.

MARX, Karl. Contribuição para a crítica da Economia Política. Lisboa: Estampa, 1973. 
MARX, Karl. Crítica ao Programa de Gotha. In ANTUNES, Ricardo. A dialética do Trabalho. Escritos de Marx e Engels. São Paulo: Expressão Popular, 2004.

MARX, Karl. Crítica da Filosofia do Direito de Hegel. Trad. Rubens Enderle e Leonardo de Deus. São Paulo: Boitempo, 2005.

MARX, Karl. Manuscritos Econômico-filosóficos. Trad. Jesus Ranieri. São Paulo: Boitempo, 2004.

MARX, Karl. O capital: crítica da economia política. O processo de produção do capital. Tradução de Regis Barbosa e Flávio R. Kothe 3ª ed. São Paulo: Nova Cultural, 1988.

MARX, Karl. O capital: crítica da economia política. O processo de

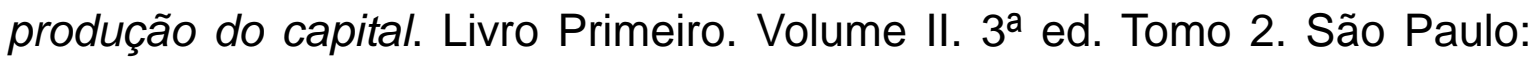
Nova Cultural, 1988.

MARX, Karl. O Capital: crítica da economia política. O processo de circulação do capital. Livro Segundo. Volume III. 3aㅡ ed. São Paulo: Nova Cultural, 1988.

MARX, Karl. O capital: crítica da economia política. O processo global da produção capitalista. Livro Terceiro. Volume IV. 3를 ed. São Paulo: Nova Cultural, 1988.

MARX, Karl. O capital: crítica da economia política. O processo global da produção capitalista. Livro Terceiro. Volume V. 3a ed. São Paulo: Nova Cultural, 1988.

MARX, Karl. Sobre a Questão Judaica. Trad. Nélio Schneider. São Paulo: 
Boitempo, 2010.

MARX, Karl. Grundisse. Trad. Mário Duayer e Nélio Schneider. São Paulo: Boitempo, 2011.

MARX, Karl, ENGELS, Friedrich. A Ideologia Alemã. São Paulo: Boitempo, 2007.

MASCARO, Alysson Leandro. Introdução à Filosofia do Direito. Dos Modernos aos Contemporâneos. São Paulo: Atlas, 2008.

MASCARO, Alysson Leandro. Introdução ao Estudo do Direito. São Paulo: Quartier Latin, 2007.

MELO, Tarso Menezes de. Direito e Ideologia: um estudo a partir da função social da propriedade rural. São Paulo: Expressão Popular, 2009.

MÉSZÁROS, István. A Educação Para Além do Capital. Tradução: Isa Tavares. São Paulo: Boitempo, 2005.

MÉSZÁROS, István. A Reconstrução Necessária da Dialética Histórica, in JINKINGS, Ivana, NOBILE, Rodrigo, István Mészáros e os Desafios do Tempo Histórico. São Paulo: Boitempo, 2011, p. 235-265.

MÉSZÁROS, István. A Teoria da Alienação em Marx. Trad. Isa Tavares. São Paulo: Boitempo, 2006.

MÉSZÁROS, István. Estrutura Social e Formas de Consciência - A Determinação social do método. Trad. Luciana Pudenzi, Francisco Raul Cornejo e Paulo Cezar Castanheira. São Paulo: Boitempo, 2009. 
MÉSZÁROS, István. Estrutura Social e Formas de Consciência II - A Dialética da Estrutura e da História. Trad. Rogério Bettoni. São Paulo: Boitempo, 2011.

MÉSZÁROS, István. Filosofia, Ideologia e Ciência Social. Trad. Ester Vaisman. São Paulo: Boitempo, 2008.

MÉSZÁROS, István. Marx Filósofo. In HOBSBAWN, Eric J. História do Marxismo. O marxismo no tempo de Marx. Vol. 1. Trad. Carlos Nelson Coutinho e Nemésio Salles. 3ª Ed., Rio de Janeiro: Paz e Terra, 1987.

MÉSZÁROS, István. Marxismo e Direitos Humanos. In Filosofia, Ideologia e Ciência Social. Trad. Ester Vaisman. São Paulo, Boitempo, 2008.

MÉSZÁROS, István. Para Além do Capital. Rumo a uma Teoria da Transição. Trad. Paulo César Castanheira e Sérgio Lessa. São Paulo: Boitempo, 2002.

MÉSZÁROS, István. O Desafio e o Fardo do Tempo Histórico. Trad. Ana Cotrim e Vera Cotrim. São Paulo: Boitempo, 2007.

MÉSZÁROS, István. O Poder da ideologia. Trad. Paulo César Castanheira. São Paulo: Boitempo, 2004.

MIAILLE, Michel. Introdução Crítica ao Direito. Trad. Ana Prata. Lisboa: Estampa, 2005.

PASUKANIS, Eugeny Brovislanovich. A teoria geral do direito e o marxismo. Rio de Janeiro: Renovar, 1989.

PINASSI, Maria Orlanda. Da Miséria Ideológica à Crise do Capital. Uma 
Reconciliação Histórica. São Paulo, Boitempo, 2009.

PINKARD, Terry. German Philosophy - 1760-1860 - The Legacy of Idealism. Cambridge: Cambridge, 2002.

PIPPIN, Robert. Hegel's practical philosophy: the realization of freedom. In AMERIKS, Karl (ed.). The Cambridge Companion to German Idealism. Cambridge: Cambridge, 2000.

STROZAKE, Juvelino (org.). Questões Agrárias: julgados comentados e pareceres. São Paulo: Método, 2002.

TRINDADE, José Damião de Lima. Os Direitos Humanos na Perspectiva de Marx e Engels: emancipação política e emancipação humana. São Paulo: Alfa-Ômega, 2011.

TRINDADE, José Damião de Lima. História Social dos Direitos Humanos. São Paulo, Peirópolis, 2002. 